enorden 



\section{Nordic Cooperation with Russia in Education and Research}

Eeva Korteniemi 


\section{Nordic Cooperation with Russia in Education and Research}

TemaNord 2011:545

ISBN 978-92-893-2250-8

(C) Nordic Council of Ministers, Copenhagen 2011

Print: Kailow Express ApS

Copies: 100

Coverphoto: Image Select

Printed in Denmark

This publication has been published with financial support by the Nordic Council of Ministers But the contents of this publication do not necessarily reflect the views, policies or recommendations of the Nordic Council of Ministers.

www.norden.org/publications

\section{Nordic co-operation}

Nordic co-operation is one of the world's most extensive forms of regional collaboration, involving Denmark, Finland, Iceland, Norway, Sweden, and Faroe Islands, Greenland, and Åland.

Nordic co-operation has firm traditions in politics, the economy, and culture. It plays an important role in European and international collaboration, and aims at creating a strong Nordic community in a strong Europe.

Nordic co-operation seeks to safeguard Nordic and regional interests and principles in the global community. Common Nordic values help the region solidify its position as one of the world's most innovative and competitive.

\section{Nordic Council of Ministers}

Ved Stranden 18

DK-1061 København K

Phone (+45) 33960200

www.norden.org 


\section{Content}

Preface

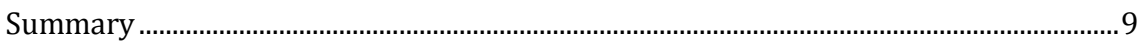

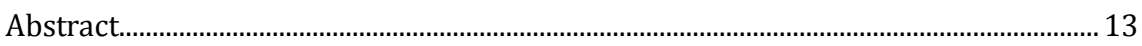

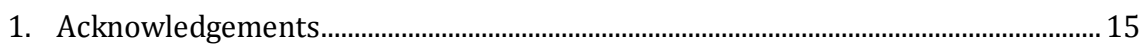

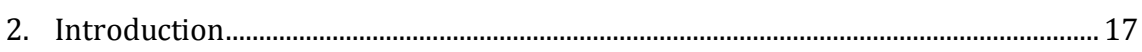

2.1 Background and research questions ............................................................... 17

2.2 The Russian education and research sector as a research object................. 20

3. Nordic countries' bilateral cooperation in education and research with

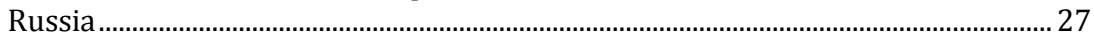

3.1 Denmark

$3.2 \quad$ Finland

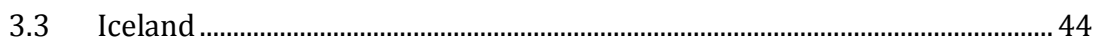

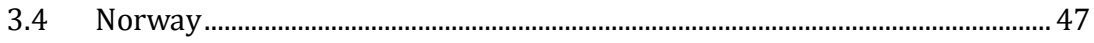

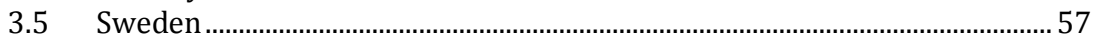

4. Intergovernmental organisations in the region: cooperation in education

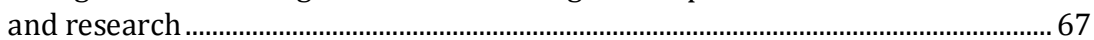

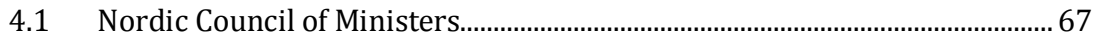

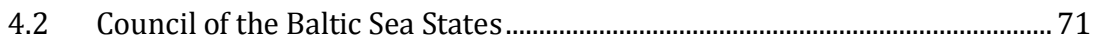

4.3 Barents-Euro Arctic Council............................................................................ 72

4.4 Arctic Council and cooperation in the Arctic region....................................... 73

4.5 Examples of other regional forms of cooperation ......................................... 75

5. Brief overview of EU-Russia cooperation in the field.................................................. 77

5.1 General framework for cooperation............................................................... 77

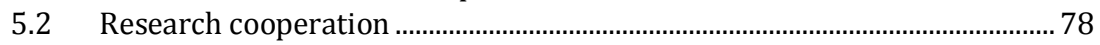

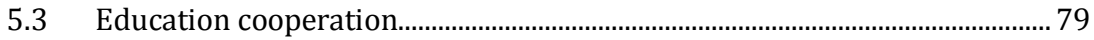

5.4 Regional EU-Russia cooperation - Northern Dimension and

European Neighbourhood and Partnerships Instrument Cross-

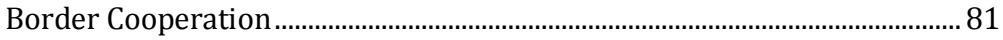

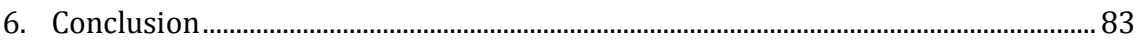

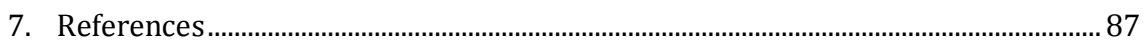

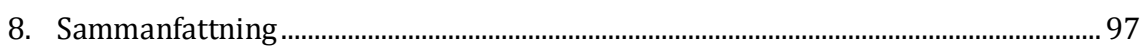

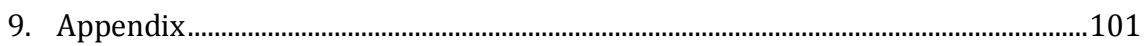

9.1 A list of organisations that have provided additional information

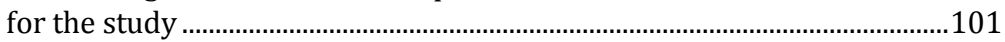

9.2 Nordic countries' bilateral education and research cooperation with Russia..........................................................................................................103

9.3 Selection of the Nordic countries' programmes for cooperation with Russia in education and research.. 



\section{Preface}

This study of Nordic Cooperation with Russia in Education and Research maps highly relevant themes of the Nordic Council of Ministers (NCM). The Nordic countries have their own bilateral agendas with Russia, but the advancement of cooperation is traditionally of considerable importance on the intergovernmental level as well. Wide-scale cooperation with Russia is necessary due to geographical realities: Norway and Finland both share borders with Russia, and the Baltic and the Barents Seas bind the rest of the Nordic Region to Russia. Good neighbourhood relations, growth and stability are important to the NCM's aim to facilitate Russia's participation as an active partner in regional cooperation.

The Nordic Council of Ministers has established the programme "Knowledge Building and Networking Programme for cooperation with North-West Russia" in 2006-2007. Cooperation in education and research plays an important role in this programme. The NCM wishes to strengthen Russia's participation in education and research cooperation by developing a well-functioning cooperation programme based on the jointly defined Nordic-Russian priorities and on joint funding. Naturally, it is vital that the programme be carefully planned, and that it supplement already existing programmes. The interplay between different programmes, including national, Russian, Nordic and EU programmes, is essential to create synergies.

Plenty of different programmes and actors work in the fields of education and research cooperation with Russia. The NCM has sought to obtain a comprehensive understanding of the activities and actors on the Nordic level, as previously only smaller-scale studies on this subject have been carried out. This study has served the needs of the NCM, but I trust that readers in the Nordic countries, Russia and the world over who are interested in Nordic-Russian cooperation will find this study valuable, and will build on its findings when future cooperation is developed.

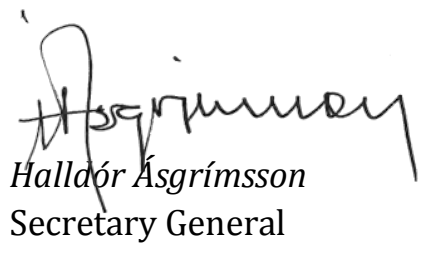

Nordic Council of Ministers 



\section{Summary}

This study, commissioned by the Nordic Council of Ministers, maps current and planned education and research cooperation that the Nordic countries (Denmark, Finland, Iceland, Norway and Sweden) have with Russia. The study explores bilateral, Nordic, regional, intergovernmental and EU levels as well as all fields of research and all educational levels: primary, upper-secondary and vocational schools, as well as higher and adult education. The study focuses on state-level programmes, but provides a brief overview of the cooperation carried out by education and research institutions operating in the Nordic countries. This study falls into at least two frameworks: the internationalisation of research and education, which is a global process, and the framework of the postSoviet space; after the collapse of the Soviet Union, Russia began expressing interest in international cooperation in the fields of research and education, while the Nordic countries began deepening their cooperation with Russia in many fields, including education and research. Section 1.2 provides a brief overview of recent developments in the Russian education and research sector.

This study focuses on the bilateral level, and Section 2 maps the education and research cooperation the Nordic countries have with Russia. The process of internationalising education and research enjoys strong support in Denmark, but current strategies do not emphasise cooperation with Russia geographically. Denmark and Russia have an agreement in the fields of culture, education and research, and a scholarship scheme is available for student/researcher exchanges within this framework. Denmark also supports and promotes the teaching of Danish in two Russian HEIs and has implemented the Economic Development Support Programme in the Pskov and Kaliningrad regions, including the restructuring of vocational institutions. Finland and Russia have two agreements in the field of education and science, and many state-level strategies emphasise their cooperation in education and research. Several funding schemes are also available for many different fields and for all levels of education and research that coordinate such cooperation. CIMO, the Centre for International Mobility, coordinates many scholarships and cooperation programmes in the field of higher education. The Academy of Finland carries out large-scale cooperation with Russian research institutes and funding agencies. The Finnish National Board of Education coordinates programmes for the upper-secondary level. In addition, the Finnish Neighbouring Area Cooperation Programme funds several educational projects with Russia. Furthermore, several insti- 
tutes/universities focus on Russia. Iceland, however, does not prioritise bilateral cooperation in education and research with Russia, and the scale of cooperation is quite small. Iceland's agreement with Russia in the fields of culture, science and education is not particularly active, and no plans seek to enhance such cooperation in the near future. Norway has adopted strategies that emphasise cooperation in the High North, including cooperation with Russia in education and research. Norway has at the moment two state-level agreements with Russia in the fields of education and research. Many scholarships and cooperation programmes for different fields and levels are coordinated by the Norwegian Centre for International Cooperation in Higher Education, the Norwegian Research Council and the Norwegian Barents Secretariat. In addition, the Norwegian Research Council administers several research programmes that also focus on Russia. Institutional-level actors have also invested some of their own resources in cooperation with Russia. Sweden and Russia currently have no agreements in the field of education and research. The main resource for cooperation with Russia in education and research is the Swedish Institute's Visby Programme, which prioritises cooperation with Russia, but the programme is likely to change after the possible merger of Sida's Baltic Sea Unit with the Swedish Institute. Other forms of cooperation in education are also available, and in the field of research, Russia has been defined as a strategically important region. In general, many institutions of higher education and research as well as some schools in the Nordic countries enjoy cooperation agreements with their Russian counterparts. Such cooperation is funded through the abovementioned state programmes or other funding sources, including those listed below.

Section 3 maps cooperation in education and research among regional intergovernmental organisations, including the Nordic Council of Ministers, the Council of the Baltic Sea States, the Barents Euro-Arctic Council and the Arctic Council. All these organisations enjoy some measure of cooperation related to education and research, but the Council of the Baltic Sea States and the Nordic Council of Ministers have more resources to implement Russian-Nordic cooperation in education. Section 4 briefly discusses EU-Russia cooperation, as it is an important framework from the Nordic perspective as well, since all the Nordic Countries participate in cooperation either through their member state status or the EEA agreement.

This study shows that all Nordic countries engage in some bilateral cooperation with Russia in education and research, although the resources and priorities each country attaches to such cooperation differ considerably. Cooperation abounds in the geographical region in proximity to Russia (Northern Norway and Finland). North-West Russia has traditionally been the target area for cooperation, but the geographical scope has broadened in recent years. Regional intergovernmental organ- 
isations and the EU supplement cooperation resources on the national and bilateral levels and provide a framework for multilateral cooperation with Russia. Such cooperation is most active in the fields of higher education and research. The field of adult education, however, sees very little formal cooperation, but in the field of basic education and on the upper-secondary and vocational levels, some cooperation exists. Russia's economic growth and development have resulted in a shift from assistance programmes to rhetoric on cooperation, accompanied by mutual priorities and shared funding. In the field of research, Russia has already participated in the costs of joint research projects. Russia has also provided funding for EU-Russia cooperation programmes, such as ENPI CBC. Thus, the question of joint programme priorities and shared funding is also highly relevant, even in Nordic-Russian cooperation. 



\section{Abstract}

This study, commissioned by the Nordic Council of Ministers, maps current and planned cooperation in education and research that the Nordic Countries (Denmark, Finland, Iceland, Norway and Sweden) have with Russia. The study includes bilateral, Nordic, regional, intergovernmental (Nordic Council of Ministers, the Council of the Baltic Sea States, the Barents Euro-Arctic Council and the Arctic Council) and EU levels. The focus is on the bilateral, national level. The study covers all fields of research and all educational levels: primary and upper-secondary schools, as well as vocational, higher and adult education. This study falls into at least two frameworks: the internationalisation of research and education, which is a global process, and the framework of the post-Soviet space; after the collapse of the Soviet Union, Russia began expressing an interest in international cooperation in the fields of research and education, while the Nordic countries began deepening their cooperation with Russia in many fields, including education and research.

This study shows that all Nordic countries engage in some measure of bilateral cooperation with Russia in education and research, although the resources and priorities each country allocates to such cooperation differ considerably. Cooperation abounds in the geographical region in proximity to Russia (North Norway and Finland). Northwest Russia has traditionally been the target area for cooperation, but the geographical scope has broadened in recent years. Regional intergovernmental organisations and EU supplement cooperation resources on the national and bilateral levels and provide a framework for multilateral cooperation with Russia. Such cooperation is most active in the field of higher education and research. The field of adult education, however, sees very little formal cooperation; in the field of basic education and on the uppersecondary and vocational levels, some cooperation nevertheless exists. Russia's economic growth and development have resulted in a shift from assistance programmes to rhetoric on cooperation with mutual priorities and shared funding. In the field of research, Russia has already participated in the costs of joint research projects. Russia has also provided funding for EU-Russia cooperation programmes, such as the ENPI CBC. Thus, the question of joint programme priorities and shared funding is also highly relevant, even in Nordic-Russian cooperation. 



\section{Acknowledgements}

This study, commissioned by the Nordic Council of Ministers, has been carried out by the Aleksanteri Institute, which is the Finnish Centre for Russian and Eastern European Studies at the University of Helsinki. Professor Markku Kivinen, Director of the Aleksanteri Institute, has been the project leader, while Eeva Korteniemi has authored the publication and executed the majority of the research work. Vilja Liikanen and Dilorom Akhmedzhanova (Research Fellow at the European University at Saint Petersburg) assisted in the data collection. Dilorom Akhmedzhanova and Sari Eriksson have shared their views on the development and internationalisation of Russian educational sectors. Special thanks go to them all as well as to Anna Korhonen and Dr Hanna Ruutu at the Aleksanteri Institute for their support and comments throughout the project.

The Aleksanteri Institute extends its gratitude to those tens of persons at the Nordic ministries, intergovernmental organisations, education and research agencies, regional offices, universities, research institutes and schools who have openly provided additional information on their activities in education and research with Russia and thus contributed to the study. Special thanks also go to the researchers of the Nordic Russian and Eastern European studies network, who comprise representatives from all the Nordic countries, for their valuable insights. 



\section{Introduction}

\subsection{Background and research questions}

These days, the cooperation of the Nordic countries with Russia in education and research is active. This cooperation can not only be viewed from at least two perspectives, it can also be placed in the larger framework of globalisation; education and research are constantly undergoing internationalisation, which began in earnest in recent decades. Although this increased cooperation in education and research with Russia can be seen from that perspective, the collapse of the Soviet Union and Russia's political reform in the beginning of the 1990s also opened new doors to intensifying cooperation in many fields. Russia gradually became interested in international cooperation in education and research, and the Nordic countries, especially Finland, Norway and Sweden, began formulating their bilateral research and education agendas with Russia. In addition to bilateral agendas, cooperation with Russia has been taking shape on the intergovernmental level: the Nordic Council of Ministers (NCM) and the Council of the Baltic Sea States (CBSS) have been active cooperation developers. EU-Russia relations are another important framework to consider in this respect. ${ }^{1}$

A joint Nordic aim has been to build a lively and stable border region in the European North, to promote peace, security and democracy around the Baltic Sea area, and to enhance the prosperity of the region. ${ }^{2}$ As an emerging neighbouring economy, Russia is an important partner for the Nordic countries, not only because of its proximity, but also from an economic point of view. It would be beneficial for all parties to explore opportunities to deepen cooperation more aggressively. ${ }^{3}$ One of Russia's regional priorities has been to develop practical interaction with the Nordic countries and to implement joint cooperation projects in

\footnotetext{
1 cf. University of Turku (2009) Quality Handbook of Higher Education in Finland and Russia, Turku: University of Turku, pp. 160, 163-164; Belov Valeriy (2005) "Problems of the establishment and implementation of the academic mobility concept in Russia" in Pursiainen Christer and Medveded Sergey (eds.) The Bologna Process and its Implications for Russia, RECEP: Russia, pp. 27-28; Aasland Aadne (2007) Development in Research. An Outline of the Science Systems in Russia and the Baltic States, Oslo: NordForsk, pp. 20-22; Zornikov Igor (2004) "Internationalization and academic mobility in Russian universities" in Shattock Michael (ed.) Entrepreneurialism and the transformation of Russian universities, pp. 291-292.

2 cf. Ministry of Foreign Affairs, Denmark (2009b) "Russia"; Ministry for Foreign Affairs, Iceland, "The Nature of Nordic Cooperation"; Ministry of Foreign Affairs, Norway (2007) "Samarbeid med Russland i nordområda”; Ministry for Foreign Affairs, Sweden (2011) "Ryssland”; Ministry for Foreign Affairs, Finland (2009) Russia Action plan.

${ }^{3}$ Ketels Christian (2010) Global Pressure - Nordic Solutions? Nordic Globalization Barometer 2010, Copenhagen: Nordic Council of Ministers, p. 58.
} 
the Barents/Euro-Arctic/Arctic region within the framework of a multilateral mechanism. ${ }^{4}$

The environment and health have traditionally been important fields of cooperation between the Nordic countries and Russia. The Nordic countries have also promoted human rights and democracy, and cooperation has also been intense in the fields of education and research. This study focuses on cooperation in education and research, and maps the forms of this cooperation between the Nordic countries and Russia. Until now, only a few smaller-scale studies have been carried out on the subject, ${ }^{5}$ mainly covering only one country, one study level or one research activity. The impetus for this study arose from the Nordic Council of Ministers, which is in the process of establishing a joint cooperation programme in education and research with Russia. To develop an innovative programme, it is important to know who the actors are and what kind of bilateral activities are already taking place on the Nordic level and on the bilateral, country-by-country level with Russia.

This study maps current and planned forms of cooperation in education and research between the Nordic countries and Russia. It does not include all cooperation programmes with Russia since the 1990s, but focuses on more recent years and on cooperation currently ongoing or planned for the near future. Although this study covers all fields of research and all educational levels, including primary, upper-secondary and vocational schools, higher and adult education, it does not provide exhaustive information or statistics on all schools/HEIs/research institutes cooperating with Russia. Some actors engaged in intensive cooperation, however, are highlighted. The focus of this study is on the countryby-country level of bilateral cooperation with Russia. As this study covers the education and research sectors of all the Nordic countries, their respective descriptions remain on the general level, and taking into account the scope of this study, it provides little highly detailed information. In addition, this study also maps activities carried out by four intergovernmental organisations on the Nordic level. Furthermore, it describes cooperation with Russia carried out in the framework of the European Union on a general level, as such cooperation supplements existing bilateral and Nordic cooperation. Other programmes and forms of cooperation with Russia obviously exist as the initiatives of other countries, ${ }^{6}$ but they fall outside the scope of this study, as this study

\footnotetext{
${ }^{4}$ Ministry of Foreign Affairs, Russian Federation (2008) "The Foreign Policy Concept of the Russian Federation". ${ }^{5}$ See, for example, Delegation of the European Commission to Russia (2009) Compendium on Science \& Research Cooperation between the European Union and the Russian Federation; Eduards Krister, Krivonos Michail and Rylander Lars (2009) Det Svenska stödet till reformprocessen i Ryssland 1991-2008, Stockholm: Sida; Aasland Aadne (2007) Development in Research. An Outline of the Science Systems in Russia and the Baltic States, Oslo: NordForsk; Mustajoki Arto (2007) Yliopistojen Venäjä-yhteistyön ja Venäjä -osaamisen kehittäminen, Opetusministeriö: Helsinki; University of Turku (2009) Quality Handbook of Higher Education in Finland and Russia, Turku: University of Turku.

${ }^{6}$ For example, programmes by Germany, Great Britain, the Netherlands, France, Canada, the USA, etc.
} 
focuses on Nordic-Russian cooperation. NGO and business cooperation in this field is excluded.

This is not a comparative study; it aims not to compare cooperation between different Nordic countries or intergovernmental organisations, but to provide a list of various forms of cooperation. Even if the study does not attempt to explain why some countries or institutes enjoy more cooperation with Russia than do others, the conclusion nevertheless presents some general observations. Instead of cooperating bilaterally with Russia, some Nordic countries may favour multilateral forms, such as EU or regional intergovernmental organisations, to cooperate with Russia. Analyses of such political decisions, however, remain outside the scope of this study. It is also worth pointing out that this study is no evaluation either; it aims not to evaluate the profitability, effectiveness or sustainability of the cooperation Nordic countries have executed with Russia. This study may, however, refer to some activities as a particularly successful or poor form of cooperation based on a third party evaluation.

This study was completed between February 2010 and January 2011. The material includes strategies relating to Russia, agreements and programme details of the five Nordic countries (Denmark, Finland, Iceland, Norway and Sweden), four intergovernmental organisations operating in the region, and the EU. Information available online or in printed form has been supplemented with queries, executed by telephone, e-mail or in person, especially in order to obtain more information on any planned activities (see Appendix 1). This study uses mainly Nordic sources, so no interviews were conducted in Russia. Section 1.2 offers the reader a brief glance at current Russian trends in the internationalisation of education and research as an introduction to the subject.

The second chapter lists the forms of cooperation in bilateral education and research in which the Nordic countries and Russia have engaged. The sections are unequal in measure, because Finland, Norway and Sweden have engaged in more forms of cooperation than have Denmark and Iceland. The third section provides information on the cooperation carried out by the Nordic countries and Russia under the auspices of the Nordic Council of Ministers, the Council of the Baltic Sea States, the Barents Euro-Arctic Council and the Arctic Council. The third section presents an overview of cooperation in education and research between the EU and Russia. The conclusions present different forms of cooperation on different levels of education and research, as well as the study results.

The study is of use on both an international and national level. During the project, it became obvious that even within one country, not all the actors operating in the field had a clear picture of the cooperation on the national level. The study also serves an international audience: actors in different countries can become acquainted with the forms of cooperation between the Nordic countries and Russia as a whole. 


\subsection{The Russian education and research sector as a research object}

\subsubsection{Overview of the structure of education and research}

The aim of this section is to present an overview of the Russian education and research sector. ${ }^{7}$ The 1992 law on education is currently under revision, and after implementation of the new law, the following description is likely to change slightly.

General education in Russia is divided into three levels: primary general education (compulsory, four years), lower-secondary education (compulsory, five years) and upper-secondary education (two years, not compulsory - at least not yet). These schools can be either general schools, general schools with intensive learning programmes, gymnasiums or lyceums. Most of the schools are public, but there are also private schools offering general education, even though their share of the total number of schools is tiny. ${ }^{8}$

Technical and vocational education is divided into two levels: basic vocational education and mid-level professional education. Basic vocational education is practically oriented, and after completing the degree, students are entitled to practice a specific profession. Mid-level professional education trains students to be mid-level professionals, such as technicians, accountants, preschool and primary school teachers, nurses and midwives. ${ }^{9}$ Public institutions of general and vocational education are funded by regional and local authorities.

A law on Higher and Postgraduate Professional Education from 1996 is currently also under revision. HEIs include universities, academies and institutions, and may be either private (no state funding) or public institutions (funding from the federal budget). These three types of HEIs are considered equal in terms of academic standard, award and admission requirements, although differences may exist with regard to the quality and level of teaching. After the Soviet era, many institutions that were previously called polytechnics, medical institutes or agricultural institutions, have received university status. Thus, an unofficial distinction exists between the old classical universities and the new universities, which have acquired their university status only recently. The specialist degree, which is awarded after five years of study at a HEI, re-

\footnotetext{
${ }^{7}$ For detailed information in English on Russian education and research structure, see: University of Turku, Quality Handbook; Norric (2005) The system of education in Russia; Ministry of Education and Science and State University - Higher School of Economics (2007) OECD Thematic Review of Tertiary Education; Country Background Report for the Russian Federation; Aasland Aadne, Development in Research.

8 University of Turku, Quality Handbook, pp. 54-59; Norric, The system of education in Russia, pp. 17-32. ${ }^{9}$ Ibid
} 
mains the most popular degree, although Bachelor's and Master's degrees were introduced as early as the 1990s. ${ }^{10}$

With regard to research, it is worth noting that research in the Soviet Union was of high quality in several different scientific fields: theoretical physics, mathematics, space research, ICT, chemistry and materials, medicine, biology and earth studies. Since the end of the Soviet era, the research sector has undergone several changes. The Ministry of Education and Science bears the overall responsibility for developing its policy and legislation. ${ }^{11}$ The role of the Russian Academy of Sciences (RAS) (www.ras.ru) has traditionally been strong, but new policies have recently been introduced to support the increasing role of the research conducted at universities. Specific actions have been introduced to integrate science and education, and competitions have been arranged for the status of "National Research Universities".12 Although the RAS is likely to remain central and to receive funding from the state budget in future, several new actions, such as competition and peer-review, have been established for the division of funding. These developments have partly resulted from international collaboration, which has increased pressure in favour of peer review and competition. Established in the early 1990s, the two main foundations that fund research are the Russian Foundation for Basic Research (www.rfbr.ru) and the Russian Foundation for Humanities (www.rfh.ru). These foundations enjoy the support of state funding and have organised several joint calls with foreign funding organisations. ${ }^{13}$

\subsubsection{National programmes for education and research}

After the collapse of the Soviet Union, funding for education and research in Russia decreased. However, much has happened in the economic sphere since the early 1990s, and the economy in Russia has been growing. One of the main questions in Russian internal politics in the 2000s has been the rising quality in the living standards of Russian citizens. Russia's dynamically developing national economy and the country's economic potential have opened doors to the development of different sectors of society. The Government of the Russian Federation has defined four national priority areas: health, agriculture, housing and education. Several sub-projects in the framework of the National Priority Project in the field of education, comprising all the levels of education, have been carried out on the basis of competition. These projects have

\footnotetext{
10 University of Turku, Quality Handbook, pp. 59-71; OECD (2004) Survey of Higher Education Systems, pp. 56-60, supplemented with interview data.

${ }^{11}$ Aasland Aadne, Development in Research, pp. 8-10.

12 Ministry of Education and Science, Russian Federation (2010c) "НАЦИОНАЛЬНЫЕ

ИССЛЕДОВАТЕЛЬСКИЕ УНИВЕРСИТЕТЫ".

${ }^{13}$ Aasland Aadne, Development in Research, pp. 10-22, supplemented with interview data.
} 
included, among others, the following themes: innovative schools, school equipment, the modernisation of regional systems of education, introduction of the internet into the education process, federal universities, classroom management and many others. ${ }^{14}$

In addition, several Federal Target Programmes for education and research have been carried out. The Federal Target Programme for education in 2006-2010 aimed to develop education systems in the Russian Federation by developing and improving educational technology, developing the quality of educational services and the quality assurance system, enhancing the efficacy of the educational administration and improving its economic mechanism. ${ }^{15}$ The Russian Ministry of Education and Science is currently drafting a new Federal Target Programme. The idea is to assist and encourage regions to develop the level of education independently. The programme will help to establish regional centres of excellence, which provide the best early-childhood education, school education and training centres for primary and secondary vocational education as well as for the retraining of adults. ${ }^{16}$ The Federal Target Programme "Scientific-technological base of Russia" in 2007-2012 includes the following priority areas: Life systems (life sciences), nanosystems and materials industry, information and telecommunication systems, rational use of nature, and energy and energy efficiency. The programme supports cooperation with the EU's Seventh Framework Programme. ${ }^{17}$

Closer examination of recent strategies reveals that more financial resources and strategic priorities have been focused on the education and research sectors. However, the impact of the programmes cannot be assessed by analysing the strategies alone, and thus interviews are required to obtain a detailed picture of the improvements.

\subsubsection{Internationalisation of Russian higher education and research}

Several studies have explored the internationalisation of Russian higher education and research. Because cooperation in the field of research and

\footnotetext{
${ }^{14}$ Совет при Президенте России по реализации приоритетных национальных проектов и демографической политеке (2006) "Приоритетные национальные проекты"; Ministry of Education and Science, Russian Fed eration (2010d) "ПРИОРИТЕТНЫЙ НАЦИОНАЛЬНЫЙ ПРОЕКТ "ОБРАЗОВАНИЕ"'; Ministry of Education and Science, Russian Federation, "PRIORITY NATIONAL PROJECT "EDUCATION"'; Ministry of Education and Science and State University - Higher School of Economics, OECD Thematic Review of Tertiary Education, pp. 7, 18, supplemented with interview data.

15 Ministry of Education and Science and State University - Higher School of Economics, OECD Thematic Review of Tertiary Education, p. 18.

16 Ministry of Education and Science, Russian Federation (2010b) "Mr. Putin and Mr. Fursenko discussed the guidelines for a new programme to advance education".

17 Ministry of Education and Science, Russian Federation (2006) "О федеральной целевой программе

"Исследования и разработки по приоритетным направлениям развития научно-технологического комплекса России на 2007-2012 годы"”.
} 
higher education is the focus of this study, a brief overview of the topic follows. Also, an interesting question is Russia's potential to participate in the costs of international cooperation.

During the Soviet era, HEIs did not actively participate in international cooperation because of the ideological and political reasons. Whatever international cooperation that did take place focused mainly on academic mobility and joint research projects with other socialist countries. As a result, Russian institutions of higher education joined international and European processes later than did those of other countries. ${ }^{18}$ Today, the framework for international cooperation is defined in the federal law "On Education", which gives educational institutions the right to establish direct international connections, and in the law "On Higher and Post-graduate Professional Education", which defines the forms of international cooperation. By law, Russian HEIs have the right to participate in international cooperation in following ways: 1) participating in bilateral and multilateral exchange programmes for students, postgraduate students, doctoral students and teaching staff; 2) conducting joint research and organising conferences and other scientific events; 3) implementing basic and applied research projects and the R\&D commissions of foreign legal entities; 4) participating in international programmes to develop higher education. ${ }^{19}$

Regional centres of international cooperation and academic mobility (RCAMs) have been established since 1990s as the initiatives of universities, and have benefited from federal support. The aim of the RCAMs is to promote the effective implementation of international and external economic activities in education. The RCAM in north-western Russia is among the oldest. ${ }^{20}$ It is worth mentioning that the large public universities which receive state funding have enjoyed more economic resources to run international cooperation than have small private institutions, and the leading Russian HEIs, at least, possess sufficient human resources to conduct and participate in international cooperation: "A critical mass of qualified administrators and educators is being formed in Russia, who understand the importance of internationalization in higher education, and who together make up the intellectual resource for its implementation ... The HEI community is beginning to organize itself, and to influence state policy in the sphere of higher education in the Russian Federation." 21 According to Zornikov, Russian universities that

\footnotetext{
18 Zornikov Igor (2004) “Internationalization and academic mobility in Russian universities” in Shattock Michael (ed.) Entrepreneurialsm and the transformation of Russian universities, pp. 291-292. 19 Ministry of Education and Science, Russian Federation (1992) ЗАКОН РОССИЙСКОЙ ФЕДЕРАЦИИ "Об образовании", chapter 6, article 57 and Ministry of Education and Science, Russian Federation, ФЕДЕРАЛЬНЫЙ ЗАКОН (1996) "О высшем и послевузовском профессиональном образовании", chapter 6, article 33 20 Pelikhov Nikolay and Zverev Nikolay (2004) "Interuniversity co-operative institutions for academic mobility", in Shattock Michael (ed.) Entrepreneurialsm and the transformation of Russian universities, pp. 304-307. ${ }^{21}$ Ministry of Education and Science and State University - Higher School of Economics, OECD Thematic Review of Tertiary Education pp. 166.
} 
have participated in international cooperation have been successfully reforming their internal activities as well. ${ }^{22}$

Looking back to the 1990s and 2000s, programmes for international cooperation and academic exchanges with Russian participation have received funding mainly from external, foreign sources. This study maps programmes in which Nordic countries cooperate with Russia, but plenty of other bilateral programmes benefit from funding by other countries. Some international projects have benefitted by Russian funding, but thus far such funding has been unequal. For example, in the Finnish neighbourhood area cooperation programme, Russian participants in education projects have co-financed staff costs as well as costs related to premises, among others. However, discussion on the Russian side has focused on a change from the role of recipient to full-fledged partner with foreign HEIs and organisations. ${ }^{23}$ In the field of research, each partner tends to cover its own costs in international cooperation, and the Russian partners have begun to cover their share of the costs in joint bilateral research projects/programmes. ${ }^{24}$ The Russian financial share in EU-Russia projects is described in section 4.

Thus far Russia, has had relatively few of its own international cooperation projects in the fields of education and research. However, one of the cooperation programmes has involved Russian government scholarships awarded to foreign students to come and complete a degree/exchange studies in Russia. Russian authorities have defined quotas for different citizens (the quota for Finnish students, for example, has been limited to 30 study places annually). The scholarship programme has provided free tuition, a monthly grant of the same amount Russian students receive, and a dormitory place of the same monthly rent as Russian students pay. ${ }^{25}$ In 2010, a new programme called "Attracting leading scientists to Russian universities" was established for professors. Scientists from all countries and of all nationalities were eligible to apply in the 2010 call. The programme receives funding from the federal budget, and the budget for $2010-2012$ is about 12 billion Russian rubles. ${ }^{26}$ To promote Russian language, literature and culture worldwide, President Putin signed in 2007 a decree for the establishment of the

\footnotetext{
22 Zornikov, "Internationalization and academic mobility in Russian universities", p. 293. 23Ministry of Education and Science and State University - Higher School of Economics, OECD Thematic Review of Tertiary Education p. 155-156; Toivonen N. R. (2004) "Regional international co-operation and development as a way of funding a university: the case of Petrozavodsk State University" in Shattock Michael (ed.) Entrepreneurialsm and the transformation of Russian universities, pp. 180-190; Ministry for Foreign Affairs, Finland (2011b) Suomen ja Venäjän välinen lähialueyhteistyö vuosina 2004-2009, p. 52. 24 Based on interview data.

${ }^{25}$ Ministry of Education and Science, Russian Federation, "Education in Russia for foreigners".

${ }^{26}$ Ministry of Education and Science, Russian Federation (2010a) "Attracting leading scientists to Russian universities".
} 
Russkiy Mir Foundation (www.russkiymir.ru), which supports Russian language teaching programmes abroad. ${ }^{27}$

In recent years in the field of internationalisation of education, the most highly developed directions on the Russia's state level policies include cooperation in the post-Soviet education area with the independent states of the former Soviet Union and integration into the European higher education area. Russia joined the Bologna process in 2003. The geographical location of universities guides the international cooperation. The HEIs in the Russian Far East, for example, develop cooperation more actively with countries of the Asia-Pacific region and North Ameri$\mathrm{ca}$, and have benefitted from the international cooperation programmes of the USA, Canada and Japan. And HEIs in the European part of Russia enjoy strong contacts with European universities thanks to the availability of European and bilateral programmes with the region. ${ }^{28}$ This study maps programmes in which Nordic countries cooperate with Russia.

27 Russkiy Mir Foundation, "About Foundation".

${ }^{28}$ Ministry of Education and Science and State University - Higher School of Economics, OECD Thematic

Review of Tertiary Education pp. 25-26. 



\section{Nordic countries' bilateral cooperation in education and research with Russia}

This section maps state- or regional-level bilateral programmes in education and research with Russia and summarises existing state agreements with Russia in this field. As the focus is not on the institutional level, this study provides no list of all the Nordic countries' education and research institutions that cooperate with Russian counterparts. However, a brief overview of cooperation on the institutional level is provided so as to illustrate the forms of cooperation. The level of bilateral cooperation with Russia clearly varies between the Nordic countries. Reasons for this variation; some Nordic countries, especially Finland and Norway, have developed more cooperation programmes with Russia than have other Nordic countries. The aim of this study is not to provide analytical reasoning for this. Naturally, some Nordic countries will have been more interested than others in engaging in cooperation with Russia through multilateral cooperation, and thus may not have been particularly active in developing a bilateral agenda with Russia. Also, those Nordic countries with considerable bilateral activity in cooperation with Russia might have obviously been active in promoting cooperation with Russia on the multilateral level. This study does not offer analysis or background for the political decisions of the Nordic countries or Russia to cooperate.

\subsection{Denmark}

\subsubsection{Overview}

The internationalisation of education plays an important role in the political agenda in Denmark, and different actors, such as the government, labour market bodies and educational institutions, are active in the field. ${ }^{29}$ In recent years, the Danish Ministry of Education, the Ministry of Science, Technology and Innovation and other agencies have launched

29 Danish Agency for International Education (2010b)"International Cooperation and Mobility". 
several strategies for internationalising education and research. ${ }^{30}$ Cooperation with Russia, however, is not emphasised as a geographical target. Danish-Russian bilateral cooperation in education and research is often characterised as cooperation without cooperation. Several respondents felt it unnecessary to discuss the subject due to the lack of such cooperation. This attitude is understandable, as Danish international education and research strategies do not emphasise cooperation. When you look into the subject more thoroughly, however, it turns out that some bilateral cooperation nevertheless exists.

\subsubsection{Cultural Agreement Programme with Denmark and Russia}

The general framework for bilateral cooperation in education and research between Denmark and Russia is the Agreement on Cooperation between the Government of the Russian Federation and the Government of the Kingdom of Denmark in the fields of Culture, Science and Education, signed in Copenhagen on 4 November 1993. The agreement, valid until further notice, requires both parties to strengthen their cooperation in the fields of culture, science and education through direct connections and exchanges between institutions of education and research. The agreement provides for the exchange of researchers, teachers, pupils and students and supports the organisation of joint seminars, scientific and educational visits. ${ }^{31}$ The agreement is probably one of the most important bases for bilateral cooperation in the field. Denmark is currently engaged in 28 bilateral cultural agreements with different countries, and grants roughly 150 scholarships annually. ${ }^{32}$

Based on that agreement, Danish Government Scholarships are available for Russian students. The Danish Agency for International Education (www.iu.dk) coordinates these scholarships, and 60 months of scholarships are granted for young Russian graduates or researchers annually. The exchange visits vary from 2 to 12 months, and for the academic year 2010-2011, five Russian students/researchers received scholarships; in the previous call, six students/researchers received a scholarship. The purpose of the scholarships is to enable students to study or conduct research at a Danish university. The system of scholarships aims to increase the establishment and development of direct con-

\footnotetext{
${ }^{30}$ For example, Undervisningsministeriet (2009) Flere studerende på studie- og praktikophold i udlandet; Ministeriet for Videnskab, Teknologi og Udvikling (2007) Internationalisering af universitetsuddannelserne; Undervisningsministeriet \& Ministeriet for Videnskab, Teknologi og Udvikling (2004) Styrket internationalisering af uddannelserne -Redegørelse til Folketinget; Undervisningsministerie (2004) Råd og vink om internationalisering hhx; Danmark evalu eringsinstitut (2003) Den internationale dimension i folkeskolen.

31 Ministry of Education and Science, Russian Federation (2009b) Международные соглашения о сотрудничестве в сфере образования, pp. 201-206.

32 Danish Agency for International Education (2010a) “Cultural Agreements" and Danish Agency for International Education (2010c) Mobilitetsstatistik for de videregående uddannelser 2008/09, pp. 33-34.
} 
tact and agreements between institutions in Denmark and Russia. Consequently, the programme gives priority to applicants affiliated with such projects. Also, the programme prioritises students who wish to study Danish language or culture, but based on previous calls, successful applicants come from many different fields. The monthly allowance is DKK 5,000, and the scholarships provide for free tuition. The cultural agreement programme also includes six scholarships for Russian students to undertake a three-week summer course in the Danish language. These courses are open to Bachelor's, Master's and Ph.D. students. ${ }^{33}$

Reciprocally, Russia offers scholarships for Danish students and researchers: up to 60 months of scholarships are awarded annually for 2-10 month-long stays. The scholarships provide for free student dormitory accommodation as well as a student stipend of the same amount as Russian students/researchers receive. Students are requested to have at least a Bachelor's degree. Furthermore, six scholarships are available annually for a Russian language course at the Pushkin Institute in Moscow in July. The scholarship covers the course fee and accommodation; the Russian embassy in Denmark administers the scholarships to Russia. ${ }^{34}$

The Agreement on Culture, Science and Education stipulates that both parties will promote the teaching and speaking of both languages (Danish and Russian). Denmark promotes the teaching of Danish in Russia through its Lecturer Scheme. This essentially means that Moscow State University and Saint Petersburg State University have employed a Danish lecturer, to whom the Danish University and Property Agency, which falls under the Danish Ministry of Science, Technology and Innovation, provides a personal subsidy. Many lecturers in other European countries, Canada, the USA and China work through this Lecturer Scheme, which aims to disseminate awareness abroad of Danish language, literature and social conditions. ${ }^{35}$

\subsubsection{Economic Development Support Programme in Kaliningrad and Pskov Oblasts, Russia 2005-2010}

The Danish Ministry of Foreign Affairs runs a Neighbourhood Programme in which Russia is among the programme's target countries. The programme is entitled "Danish-Russian Economic Development Support Programme" (www.edsp.ru) and it aims improve the living conditions of the population in the Kaliningrad and Pskov regions as a result of business development and by creating employment opportunities.

\footnotetext{
${ }^{33}$ Danish Agency for International Education (2010e) "Russia", supplemented with additional information from representatives of the Danish Agency for International Education.

34 Danish Agency for International Education (2010d) "Rusland".

35 Danish University and Property Agency (2010) "Lecturer scheme", supplemented with additional information from the Agency.
} 
Restructuring the vocational education and training (VET) system is one the subcomponents of the programme, which has been ongoing from October 2006 until January 2011. Based on information received in September 2010, Denmark has no plans to continue the programme with Russia beyond its expiration. The programme targets five vocational training institutions in Kaliningrad and Pskov regions. The programme has provided a comprehensive teacher training programme for the staff of the institutions, and has supported the development of new training programmes and curricula. At the end of the project, participants will develop a training programme and teaching material for the fields of "Food production and catering", "Tourism" and "Furniture and wood production". Århus Technical College has participated in the consortium, and has provided some experts for development of the training programmes, training material and teacher training. ${ }^{36}$

\subsubsection{School cooperation and Russian language teaching at schools}

As noted previously, Danish schools are encouraged to embark on international cooperation in education, and many international activities are now underway between Danish and foreign schools. However, cooperation on the level of compulsory and upper-secondary education with Russia is almost entirely lacking. Three towns in Denmark have Russian twin towns, and of these three, two towns (Aalborg and Aarhus) have educational cooperation with Russia. ${ }^{37}$ In fact, this cooperation is really worth mentioning, as it enjoys long traditions.

The city of Aalborg has cooperated in education with its twin town of Pushkin, near Saint Petersburg, since the early 1970s. This cooperation has sponsored visits by students, teachers, pupils, principals, and employees of the school administration on all levels of education. During over 30 years of cooperation, more than 500 persons have visited corresponding schools in Pushkin, and many Russian students, teachers and school directors have made return visits to Aalborg. Mobility from Aalborg to Pushkin has been funded by the twin town budget, the institutions' own funds and by the School and Culture Department of the City of Aalborg. 38

The city of Aarhus has also engaged in educational cooperation with its Russian twin town of Saint Petersburg, Primorsky district since 1993. The annual number of exchanges is about 45 pupils and 4-5 teachers for

36 Ministry of Foreign Affairs, Denmark (2009c) "The Neighbourhood Programme” and Ministry of Foreign Affairs, Denmark (2009a) “Economic Development Support Programme for Kaliningrad and Pskov", supplemented with additional information from the Danish MFA.

37 According to information provided by the Local Government of Denmark.

${ }^{38}$ According to information provided by the City of Aalborg. 
one direction, so in all the years of cooperation, the exchange numbers total in the thousands of visits. Both parties have considered the project a great success. The city of Aarhus has been financing the entire project since the very beginning, including the study visits of Russian students to Aarhus. ${ }^{39}$

Even Bornholm has participated in cooperation with the Kaliningrad region since the 1990s, but nowadays the cooperation takes place via the Euroregion Baltic.

In the framework of Russian language teaching, past years have seen educational cooperation with Russia, but not recently. The Danish Association for Russian language and literature teachers has organised study visits to Saint Petersburg/Moscow in the framework of cultural agreement. The same association, together with the Russian Cultural Institute in Copenhagen, has organised competitions for Russian students at schools. Winners have received a fully-paid study period in Russia. The teaching of Russian language in upper-secondary schools in Denmark has been declining, and nowadays fewer than 10 "gymnasia" schools offer Russian courses. According to respondents, Russian language is a dying subject in schools. ${ }^{40}$

\subsubsection{Cooperation in the field of higher education and mobility statistics}

The University of Copenhagen, the Copenhagen Business School and the University of Aarhus together send about $73 \%$ of all Danish exchange students abroad. These three universities also host the majority of foreign exchange students. ${ }^{41}$ All three universities enjoy bilateral agreements with Russian universities. The Copenhagen Business School maintains a student exchange agreement with the Plekhanov Russian Academy of Economics for three undergraduate and two graduate places annually; they also have a bilateral agreement with the Graduate School of Management in Saint Petersburg which offers four places annually. In addition, the cooperation is managed through CEMS (Global Alliance in Management Education), in which both universities participate. ${ }^{42}$

Aarhus and Copenhagen Universities have bilateral agreements with Saint Petersburg State University, and both of these universities also send their Russian language students to Russia for training. The Faculty of Arts at the University of Aarhus also has its own one-way exchange programme with the Faculty of Russian Language and Culture in Saint

\footnotetext{
${ }^{39}$ According to information provided by a representative of City of Aarhus.

40 Based on information from two Russian teachers.

${ }^{41}$ Danish Agency for International Education, Mobilitetsstatistik for de videregående uddannelser 2008/09, pp.

18 and 24.

${ }^{42}$ According to information provided by a representative of the CBS International Office.
} 
Petersburg State University. Every year they send approximately 10 students for a study period in Saint Petersburg, an arrangement under which Aarhus University pays for their tuition fees, transportation and visas. Russian language students at the University of Copenhagen may also spend a study period in Russia and follow a programme agreed upon between the Copenhagen teaching staff and Moscow State University. Students can apply to different sources for individual scholarships to cover their studies at MGU.43 Although Danish Ministries do not finance the programmes, these study periods are in line with the Danish Ministry of Education strategy which encourages students in teacher education programmes with a foreign language as their major to spend a study period abroad. ${ }^{4}$

Danish institutions of higher education also have a possibility to cooperate through EU programmes with Russia, such as Tempus and Erasmus Mundus, but no detailed information or statistics are available on cooperation through these schemes. However, the Tempus IV selection results indicate that a couple of funded Tempus projects include Danish-Russian participation. For example, Aalborg University coordinates a consortium on "Tempus-Tourism" with seven partners from Russia. 45

The cooperation of the universities also takes the form of receiving and sending students through the cultural agreement programme.

Russia is not among the popular exchange destinations for Danish university students; data from 2008/09 indicate that the USA is the favourite destination, followed by the UK, Germany, Australia, Spain, Canada, France, China, Italy and Sweden. Neither are Russian exchange students to Denmark in the top ten in the list of exchange students to Denmark. Similarly, Russia does not figure among the most popular countries in which to complete a full degree abroad for Danish students, and university students from Russia are not among the top ten nationalities coming to Denmark to complete an academic education. ${ }^{46}$ No specific information is available whether, after the implementation of tuition fees in Denmark, the numbers of Russian HEI students have decreased.

\subsubsection{Research cooperation}

According to the Compendium on Science \& Research Cooperation between the European Union and the Russian Federation, cooperation, development and knowledge sharing between Danish and Russian researchers have existed for several years. Institutions and research centres have established

\footnotetext{
${ }^{43}$ According to information provided by the University of Copenhagen and University of Århus.

44 Undervisningsministeriet, Flere studerende.

45 Executive Agency Education, Audivisual \& Culture (2010b) "Tempus Selection Results".

${ }^{46}$ Danish Agency for International Education, Mobilitetsstatistik for de videregående uddannelser 2008/09, pp. $14,21,36,40$.
} 
agreements on cooperation and partnership based on common interests, sometimes even with governmental financial support for projects. Cooperation has included mainly guest lectures, exchanges and the employment of guest researchers for a limited period of 12 months or less. ${ }^{47}$

The Danish Agency for Science, Technology and Innovation does not have its own bilateral agreements or cooperation with Russian research agencies. Furthermore, no funds are specifically earmarked for research cooperation between Denmark and Russia for which universities or research institutes could apply. However, the project applications of Danish researchers to various research councils may include international cooperation, including cooperation with Russian researchers and research institutions, and this cooperation can be incorporated in the application. The agency does not collect information on such research cooperation with Russia, as it is regulated by the individual universities or research institutes. ${ }^{48}$

According to one respondent, the government and ministries are generally quite enthusiastic about joint cooperation with Russia, but offer no funding to do so. Some joint projects with EU FP7 funding have been recalled, and according to the study "International Research Cooperation in the Nordic Countries", some publications have Danish-Russian coauthors, which also indicates joint international scientific cooperation. ${ }^{49}$ The following fields have either already engaged in cooperation or plan to increase cooperation in future: nanotechnology, bioenergy, quantum physics and other fields of physics, environmental and climate studies, hydrometeorology, ecology energy and Slavonic philology. Some researchers are also conducting area-based studies on Russia.50

In summary, although a measure of research cooperation with Russia already exists, it is often based on individual contacts. Such research cooperation between Denmark and Russia cannot be considered large-scale.

\footnotetext{
47 Delegation of the European Commission to Russia (2009) Compendium on Science \& Research Cooperation between the European Union and the Russian Federation, pp. 38-41.

48 Based on information provided by the Danish Agency for Science, Technology and Innovation.

${ }^{49}$ Gunnarson Magnus (ed.), International Research Cooperation in the Nordic Countries, A publication from the Noria-Net. "The Use of bibliometrics in research policy and evaluation activities", p. 20.

50 Delegation of the European Commission to Russia, Compendium, pp. 38-41. Memorandum (2010) VIII, Session of the Danish-Russian Intergovernmental Council on Economic Cooperation; Ministry of Education and Science, Russian Federation, ФЕДЕРАЛЬНОЕ АГЕНТСТВО ПО НАУКЕ И ИННОВАЦИЯМ "Семинарвыставка "Стратегия развития крупных исследовательских инфраструктур Российской Федерации и кооперация с Европейским Союзом" на базе Российского центра науки и культуры в Копенгагене", supplemented with interview data from individual researchers.
} 


\subsection{Finland}

\subsubsection{General framework for cooperation}

Finnish-Russian cooperation has long traditions in many fields. Finnish expertise on Russia and the tradition of cooperation with Russia are also recognised internationally. Cooperation in education and research is institutionalised, and opportunities for the promotion of cooperation in this field abound. CIMO (the Centre for International Mobility), the Academy of Finland and the Finnish National Board of Education have taken active roles in developing cooperation with Russia. Actors, including schools, institutions of higher education and research institutes actively participate in cooperation; in fact, most Finnish HEIs refer to cooperation with Russia in their internationalisation strategies.

The Finnish Ministry of Education carried out an extensive strategic programme entitled "Finland, Russia and International Cooperation" 51 during the years 2003-2007, resulting in the intensification and systemisation of resources for cooperation in education and research. Many outcomes of this programme, which remain ongoing, are summarised below. The Academy of Finland has also successfully executed two research programmes on Russia. In recent years, Finnish government strategies have emphasised cooperation in education and research, including a "Russia Action Plan"52 launched in April 2009. In addition, from the Finnish side, the latest strategy for internalisation of institutions of higher education identifies specific actions regarding cooperation with Russia. Finnish-Russian cooperation in research and education on the university level has also been mapped: the latest studies include a report by Professor Arto Mustajoki from 2007 on the development among Finnish universities of cooperation with Russia and the development of Russia skills. Furthermore, a study entitled "Quality Handbook of Higher Education in Finland and Russia", completed by the University of Turku (2009), took a somewhat more specific approach. ${ }^{53}$

The agreement on cooperation in the fields of culture, education and science from the year 1992, which remains valid until further notice, outlines the basis for Finnish-Russian cooperation in education and research. Relations in the fields of culture, education and scientific research are to be strengthened and further developed. Another agreement, also signed in 1992, focuses on cooperation in science and tech-

\footnotetext{
51Ministry of Education and Culture, Finland (2003) Suomi, Venäjä ja kansainvälinen yhteistyö. Opetusministeriön toimintaohjelma 2003-2007.

52 Ministry for Foreign Affairs, Finland (2009) Russia Action plan.

53 Mustajoki Arto (2007) Yliopistojen Venäjä-yhteistyön ja Venäjä -osaamisen kehittäminen, Opetusministeriö: Helsinki. University of Turku (2009) Quality Handbook of Higher Education in Finland and Russia, Turku: University of Turku.
} 
nology. ${ }^{54}$ Although these agreements lack specifics on cooperation, the Finnish side has found such agreements useful when planning new forms of cooperation. ${ }^{55}$

\subsubsection{Neighbouring area cooperation with Russia}

One instrument for cooperation has been the neighbouring area cooperation programme, which constitutes an integral part of Finland's foreign policy and is coordinated by the Finnish Ministry for Foreign Affairs. The cooperation is based on the Agreement on Cooperation in the Murmansk Region, Republic of Karelia, Saint Petersburg and the Leningrad region, signed in 1992 between the governments of Finland and the Russian Federation. During 1990-2009, Finland allocated about EUR 293 million to projects carried out jointly with Russia. Russia also provided some funding, but its financial share was significantly less than the Finnish funding. The cooperation focuses on North-West Russia, especially the Republic of Karelia, the Leningrad and Murmansk oblasts, and Saint Petersburg. The current programme period is for 2009-2011 and places particular emphasis on the promotion of economic cooperation, but also includes the areas of education and civil society. 56

The Ministry of Education and Culture has been coordinating projects in the field of higher education, and the National Board of Education has been coordinating projects that focus on vocational education and the improvement of administration in education. According to the strategy, cooperation in the field of higher education is implemented along the lines of the Bologna process. Special emphasis falls on the development, administration and quality control of the joint Master's and other educational programmes. Cooperation between business and higher education is also important. The mobility of students, teachers and researchers improves the internationalisation of HEIs. The fields of innovation, environment, forestry and health care all encourage the further education of teachers and specialists. One of the top projects in the higher education sector to have received funding for several years is the Finnish-Russian Cross-Border University (CBU). More information on CBU appears in the section on cooperation in higher education. ${ }^{57}$

\footnotetext{
54 Finlex (1992) "Asetus Venäjän kanssa yhteistyöstä kulttuurin, opetuksen ja tieteen alalla tehdyn sopimuksen voimaansaattamisesta"; Ministry of Education and Science, Russian Federation (2009b) Международные соглашения о сотрудничестве в сфере образования; Ministry of Education and Science, Russian Federation (2009a) Международные соглашения о научно-техническом сотрудничестве. 55 Ministry of Education and Culture, Finland, Suomi, Venäjä ja kansainvälinen yhteistyö, p. 23.

56 Ministry for Foreign Affairs, Finland (2010a) "Finland's cooperation with neighbouring areas"; Ministry for Foreign Affairs of Finland (2011b) Suomen ja Venäjän välinen lähialueyhteistyö vuosina 2004-2009.

57 Ministry for Foreign Affairs, Finland (2011a) "Suomen lähialuyeyhteistyö", supplemented with information provided by the Ministry of Education and Culture.
} 
In 2010, neighbouring area cooperation underwent an independent evaluation. According to the evaluation, the cooperation was both successful and effective, even from an international perspective, and met the goals set for it. Educational projects have also succeeded in developing the planned programmes, but generally speaking, the results and impacts of the educational projects have been rather modest. ${ }^{58}$ The evaluation offers several recommendations, which, along with information on the development work conducted by the Finnish MFA, will serve as the basis for the assessment of future plans for the cooperation programme. At the moment, no information is available on whether cooperation in education will remain a priority in the future also. ${ }^{59}$

\subsubsection{Resources for cooperation: mobility programmes and CIMO's cooperation with Russia}

Cooperation with Russia is defined as one of the priority areas of CIMO (the Centre for International Mobility) (www.cimo.fi), which is evident in the extensive programmes the organisation carries out. Also important is the Finnish-Russian conference on Higher Education, organised approximately every other year, alternating between a Finnish University and one of the universities in Saint Petersburg. The first conference, on the initiative of CIMO, took place in 1996 at the University of Helsinki. The latest (seventh) seminar, organised at the University of Turku in cooperation with CIMO and the Saint Petersburg Association for International Vice-Rectors, drew approximately 150 participants from Finland and Russia. The Russian participants came mainly from Saint Petersburg, Petrozavodsk, Arkhangelsk, Murmansk, Pskov and Syktyvkar.60

The Finnish Government's "Russia Action Plan" encourages Finnish and Russian students and researchers to take advantage of the opportunities for student and research exchanges in Finland and Russia, ${ }^{61}$ and opportunities for mobility either from Finland to Russia or from Russia to Finland are many.

In terms of cooperation with Russia, the flagship programme is the FIRST programme (Finnish-Russian Student and Teacher Exchange Programme). The programme, established in 2000, was first financed with pilot funding from the Ministry of Education and Culture. Later, the strategy "Finland, Russia and the International Cooperation" (2003) strengthened support for the programme, and the latest strategy for the

\footnotetext{
58 Ministry for Foreign Affairs of Finland, Suomen ja Venäjän, pp. 11, 44

59 Based on information provided by the Ministry of Education and Culture.

${ }^{60}$ Centre for International Mobility (2010a) CIMO korkeakoulutuksen kansainvälistäjänä 2009, p. 26, supplemented with additional information from the CIMO secretariat.

61 Ministry for Foreign Affairs, Finland, Russia Action plan, p. 36.
} 
internationalisation of HEIs (2009) also commits more funding resources for the programme. The programme aims to promote high quality partnerships and cooperation in higher education between Finnish and north-western Russian institutions. Specific actions include student and teacher exchanges and the organisation of intensive courses. The budget for 2011 is about EUR 600 000, the largest budget of all the programme's years. The programme is generally considered to function well, and no significant changes in the concept are planned for the near future. The programme comprises 25 networks of 55 Russian and 38 Finnish HEIs for the academic year 2010-2011. The mobility numbers have been steadily rising, and were the highest in the academic year 2009-2010. The number of teacher exchanges was 147, and for student exchanges, 312 in total. The programme strives for balanced mobility between the countries. However, more students come from Russia to Finland than the other way round. An interesting fact from the most recent academic year is that $25 \%$ of Russian FIRST students needed no scholarships to participate in the exchange. A total of nine intensive courses were organised in the academic year 2009-2010.62

CIMO also coordinates other cooperation programmes. CIMO Fellowships, for example, are open to foreign doctoral students and young researchers. The programme focuses specifically on Russia, and every year, a number of Russian doctoral students and researchers receive scholarships ranging from 3-12 months. In recent years, the budget of the programme has been about EUR 970 000, and accepted Russian scholars have comprised about $25 \%$ of selected applicants. CIMO also organises an annual winter school for which it invites talented Russian and Ukrainian students to Finland. The initiative came from three Finnish professors, and the first winter school was organised in 1997. The themes of these scientific courses vary; the theme for the winter school in 2011 , already the $15^{\text {th }}$, is entitled "Chemistry of life: from molecules to mind". The annual budget of the winter school is about EUR 40000 . Winter school participants have also been encouraged to apply for CIMO Fellowships; of the approximately 350 postgraduate students who have participated in the courses between the years 1997-2010, a total of 118 have subsequently received CIMO Fellowships. The Finnish Ministry of Education and Culture funds both programmes. ${ }^{63}$

The Ministry of Education and Culture has traditionally considered cooperation with Finno-Ugrian Minorities in Russia important, and its strategy entitled "Finland, Russia and the International Cooperation"

62 Centre for International Mobility (2011d) "Korkeakoulujen Venäjä-yhteistyö kasvoi FIRST-ohjelmassa”; Centre for International Mobility (2011c) "FIRST”; Centre for International Mobility (2011e) "Tuloksia”, supplemented with additional information from the CIMO secretariat.

${ }^{63}$ Centre for International Mobility (2011a) “CIMO Fellowships” and Centre for International Mobility (2011b) “CIMOn talvikoulu”, supplemented with additional information from the CIMO secretariat. 
specifically emphasised such cooperation. Also, according to the Russia Action Plan, ${ }^{64}$ cultivating the culture and language of Finno-Ugrians in Russia is also important. CIMO coordinates the "Kindred Nations' Scholarships for Finno-Ugrian minorities in Russia" and awards grants (annual budget is about EUR 60000 ) to young post-Master's-level researchers representing the Uralic Peoples of Russia. The objective is to promote mobility in research and teaching in fields closely related to Finno-Ugric linguistics, ethnology and folklore. The programme also strives to strengthen cultural and linguistic ties between Finland and Uralic nations. Additionally, since 1993 CIMO, has also organised an annual Kindred Nations' course (annual budget is about EUR 15 000) in Russia. These activities are part of a larger Kindred Nations' Programme funded by the Finnish Ministry of Education and Culture. ${ }^{65}$

Finnish language and culture courses also receive emphasis, and plenty of Russian students participate in these courses annually. CIMO also administers a programme, funded by the Ministry of Education and Culture, which sends Finnish language and cultural lecturers abroad. In Russia, the lecturers are sent to Moscow, Petrozavodsk, Saint Petersburg and Arkhangelsk, and junior lecturers in the field of languages have traditionally been sent to Komi, Mari, Mordva, Tver and Udmurtia (presently, only to Mordva and Udmurtia). ${ }^{66}$

The Ministry of Education and Culture through CIMO also funds a North2North exchange programme, which enables Russian students to study at Finnish partner universities, and Finnish students to study at Russian partner universities of the University of the Arctic. CIMO also awards scholarships to Finnish students to complete internships in Russia. CIMO is also the NCP for the Tempus and Erasmus Mundus programmes. Traditionally, Russia has been the most important cooperation country for Finnish HEIs in the Tempus programme, which continues to see plenty of Finnish-Russian cooperation. During the years 2000-2006, for example, about 20\% of all selected Russian joint European Tempus projects had Finnish involvement. Cooperation also takes place through the Erasmus Mundus programme, and the University of Turku coordinates a large consortium with Russian participation in the action two. ${ }^{67}$

On behalf of the Russian Education and Science Ministry, CIMO also coordinates in Finland the Russian State Scholarship Programme for foreigners. The quota for Finnish students has been about 30, and the programme provided students the opportunity to complete their degree, either in whole or in part, at Russian universities. The scholarships pro-

\footnotetext{
${ }^{64}$ p. 25.

65 Centre for International Mobility (2010b) "Kindred Nations' Scholarships for Finno-Ugrian minorities in Russia" supplemented with additional information from the CIMO secretariat.

${ }^{66}$ According to information received from the Centre for International Mobility.

67 ibid
} 
vide for free tuition and a monthly stipend of the same amount paid to Russian students in Russia. Additionally, CIMO may award a travel grant to accepted Finnish students. For the 2011-2012, no changes in the concept have been reported.68

The study of Russian language and culture in general has traditionally been one of the focuses of discussion, and is an important topic in the strategy "Finland, Russia and the International Cooperation". This strategy has strengthened the training programme in Russia for Finnish students majoring in Russian language, funded since the beginning of $2000 \mathrm{~s}$ by the Finnish Ministry of Education and Culture. All Finnish universities teaching Russian language, literature, culture and translation participate in the programme, which is coordinated by the Aleksanteri Institute. Approximately 70 students annually participate in the 10- to 14-week period of language training in Russia.

\subsubsection{Research cooperation}

The intensification of research cooperation with Russia also figured large in the Ministry of Education Strategy of 2003, and the Russia Action Plan from 2009 offered important guidelines for cooperation in research. The strategy called for diversifying and deepening research on Russia, as well as carrying out forecasting analyses on Russia and completing studies on innovation, energy and logistics in the field of social sciences, and proposed that long-term financing be guaranteed. The Russia Action Plan also stressed the role of research funding agencies, and encouraged the exploration of opportunities for joint research projects and the joint training of researchers. In addition, efforts will aim to recruit more qualified Russian researchers to Finnish universities. ${ }^{69}$

The Academy of Finland's international strategy identifies Russia as one its main areas of cooperation. The Academy of Finland (www.aka.fi) strives to support high quality research on Russia and with Russia. The Academy's latest Russia programme (2004-2007) entitled "Russia in Flux", according to an evaluation by an international panel, evidenced cutting-edge research on Russia, and added that Finnish research on Russia in the fields of economy, culture, politics and environments is among the top in the EU. In fact, the Academy has already executed many of the recommendations of the Russia Action Plan and has established close relationships and cooperation agreements with the Russian Academy of Sciences (RAS) since 1993,70 the Russian Foundation for Basic Research (RFBR) since 2000, and the Russian Foundation for Humanities (RFH) since 2005. Different kinds of cooperation take on many

${ }^{68}$ Centre for International Mobility (2011f) "Venäjän valtion apurahat".

${ }^{69}$ Ministry of Foreign Affairs, Finland, Russia Action plan, pp. 29-30, 39.

70 The Finnish Academy had an agreement with the Soviet Academy of Sciences since 1971. 
forms. With RAS, cooperation has grown in the field of researcher mobility. About 100 Russian researchers visit Finland annually, and about 7080 Finnish researchers visit Russia every year. With RFBR and RFH, the Academy has launched joint calls on research projects representing many different fields of research. This essentially means that the Russian side funds the research carried out in Russia, and the Academy of Finland funds the research carried out in Finland. Joint calls have succeeded, and the Academy of Finland plans to continue the work in the near future so that joint calls could be launched each year. ${ }^{71}$

In addition to the Academy of Finland, Tekes, the Finnish Funding Agency for Technology and Innovation, and Sitra, the Finnish Innovation Fund, also enjoy R\&D cooperation with Russia. In fact, these three organisations, together with the Ministry of Employment and Technology, Finpro, VTT and two regional offices have established a FinNode Russia centre in Saint Petersburg in 2008. The objective of the centre is to strengthen cooperation between Finland and Russia in the field of research, development and innovation. ${ }^{72}$

As noted earlier, the programme "Finland, Russia and International Cooperation" emphasised several actions, including a larger role for the Aleksanteri Institute as a national centre of expertise in the field of Russian and Eastern European studies (more information on the Aleksanteri Institute appears below). In the 1990s and 2000s, even other research departments or institutes with a strong emphasis on Russia research have received support, including the Centre for Markets in Transition (CEMAT) at the Aalto University, the Pan-European Institute at the Turku School of Economics, the Karelian Research Centre at the University of Eastern Finland, the Renvall Institute at the University of Helsinki, the Northern Dimension Research Centre at the Lappeenranta Technical University, and the Finnish Institute for International Affairs, as well as the Russian language and cultural departments at several Finnish universities.

\subsubsection{Cooperation at institutions of higher education and mobility statistics}

The study conducted in 2007 by Professor Arto Mustajoki maps the education and research cooperation of Finnish universities with Russia. All the universities engage in some form of cooperation with Russia, which often includes bilateral agreements on teacher and student exchanges as

\footnotetext{
${ }^{71}$ Academy of Finland, Research Collaboration with Russia, supplemented with additional information from the Academy of Finland.

72 Ministry of Employment and the Economy, Finland (2008) "Ministeri Pekkarinen Pietarissa: "Tulimme paikan päälle innovaatioympäristöä kuulostelemaan"”.
} 
well as joint research projects..$^{73}$ Universities use the different funding mechanisms described above, but some also allocate their own funding for cooperation with Russia. One example is the University of Eastern Finland, which has allocated EUR 2.5 million for the development of broad knowledge on Russia for 2011-2015.74

The Aleksanteri Institute (www.helsinki.fi/aleksanteri), which was established in 1996 and is affiliated with the University of Helsinki, operates as a national centre of research, study and expertise on Russia and Eastern Europe. The Institute receives annual funding from the Ministry of Education and Culture of about EUR 1.5 million, and additional funding from the University of Helsinki and external sources. Its annual budget is roughly EUR 3 million. Many of the Institute's activities figure in the Ministry of Education strategy entitled "Finland, Russia and International Cooperation". The Institute coordinates four educational training programmes, including the Finnish Graduate School for Russian and Eastern European Studies and the Finnish Master's School for Russian and Eastern European studies. The Master's School is a network of 14 Finnish universities, and for more than ten years has provided hundreds of students from many different fields the opportunity to specialise in multidisciplinary to Russian studies. The Institute offers these students mobility opportunities to attend top-level Russian universities such as the National Research University, the Higher School of Economics in Moscow, and the European University at Saint Petersburg. For purposes of researcher mobility and the advancement of international cooperation, the Institute established in 2008 a Visiting Scholars Programme which, while targeting high-level scholars from any foreign country, has thus far attracted researchers from three countries in particular: Russia, the US and the UK. The Institute also hosts Kikimora Publications, as well as information services and research projects, and regularly holds conferences, lectures and research seminars.

Another form of university-based cooperation in education is the Finnish-Russian Cross-Border University (CBU) (www.cbu.fi), which dates back to the strategy entitled "Finland, Russia and International Cooperation". The Strategy for the Internationalisation of Higher Education (2009) and the Russia Action Plan (2009) have both outlined political support for CBU. The CBU is currently a university consortium comprising five universities in Finland and five universities in Russia, and offers Master's degree programmes in five fields of study. Doctoral pro-

\footnotetext{
73 For a detailed description of the education and research cooperation Finnish universities have with Russia, see pages 26-34 in Mustajoki's study.

${ }^{74}$ University of Eastern Finland (2010) "Venäjä-osaamiseen ja opettajankoulutukseen strategiarahaa 5 miljoonaa euroa".
} 
grammes are also currently under development. ${ }^{75}$ Since 2004, CBU has received funding from the Finnish neighbouring area programme (budget EUR $1419900 €$ ), and about 200 students have participated in the programme. ${ }^{76}$ Event the Barents Cross-Border University, part of the cooperation between universities in Northern Finland and North-West Russia, is developing its Master's programmes. ${ }^{77}$

The universities of applied sciences (formerly called polytechnics) also engage in important cooperation with Russia, but this cooperation is not yet as widely studied as the cooperation taking place in the universities. The Haaga-Helia University of Applied Sciences, for example, enjoys broad cooperation with Russia, and approximately 200 Russian degree students currently study at Haaga-Helia.

Statistics for exchange studies in 2009 indicate that Russia is fifth among the nationalities of exchange students to Finland, with 425 students. Russia is not among the top ten study destinations of Finnish exchange students, but with 271 Finnish exchange students in Russia, the number is nevertheless relatively high. Among degree students, in contrast, about 1600 Russian degree students were in Finland in 2009. The corresponding number of Finnish students completing a degree in Russia is only $50 .{ }^{78}$ The interesting question is: What will happen to the number of Russian students in Finland in future if tuition fees are permanently introduced in Finland?

Statistics are also available on the numbers of Russian exchange students in Finnish vocational upper-secondary institutions. In 2009, this number was 179 students; the corresponding number of Finnish exchange students in Russia was 236 students in 2009.79 The cooperation taking place on this level is described below.

\subsubsection{Cooperation in the other fields of education}

The fields most often mentioned in connection with cooperation with Russia are the fields of higher education and research. However, one should not underestimate the important work carried out by the Finnish National Board of Education, municipalities and the networks of primary, upper-secondary and vocational schools. Individual schools, teachers and pupils are also active participants in cooperation.

\footnotetext{
75 Cross-Border University, "Study programmes"; Tahvanainen Liisa and Fors Eero (2009) "The Quality Assurance System in the Finnish-Russian Cross-Border University (CBU)" in University of Turku, Quality Handbook of Higher Education in Finland and Russia, Turku: University of Turku, pp. 219-220.

76 Ministry for Foreign Affairs, Finland, Suomen ja Venäjän, pp. 44, 102.

77 Barents Cross Border University, "Barents Cross Border University (BCBU)".

78 Centre for International Mobility (2010c) Kansainvälinen liikkuvuus yliopistoissa ja ammattikorkeakouluissa 2009, supplemented with additional information from the CIMO secretariat.

${ }^{79}$ Centre for International Mobility (2010d) Kansainvälinen liikkuvuus ammatillisessa koulutuksessa 2009.
} 
The Finnish National Board of Education (http://www.oph.fi) has engaged in cooperation with Russia since the 1990s. It not only administers a Finland-Russia programme based on mutual benefit, but also serves Finnish national needs and promotes development work in education. The programme includes networks in the field of vocational upper-secondary education and general upper-secondary education in Finland which promote knowledge of Russia. The specific actions include exchanges of teachers and students as well as open seminars, which are especially important for improving the quality of the networks. The two most established networks are the network for Russian language and culture and the network which presently unites 34 educational institutions in the field of vocational upper-secondary education. In this network students have, among other things, participated in a training period in Russia, and the exchanges have ranged from two weeks to three months. The programme has received excellent feedback from the students. 80 More pupils study Russian language in schools in Finland than in other Nordic countries.

The Finland-Russia programme also offers annual summer schools in the fields of mathematics, physics and space physics in the Moscow region for pupils in general upper-secondary schools. The summer courses are organised in cooperation with the Russian Ministry of Education and Science and its agencies. The cooperation has been ongoing for 15 years, and during the period of 1995-2006, a total of 531 pupils and 519 teachers participated in the cooperation. Competition among the students is tough, and only the best of the best are selected. In 2011, only summer school in maths is available, for which 28 pupils and a few teachers will be selected. ${ }^{81}$ In general, the Finland-Russia programme receives its budget on a yearly basis, but the cooperation has continued thus far, and is likely to continue into the near future.

The Finnish National Board of Education also allocates funding for the internationalisation of schools. Cooperation with Russia has been among the programme priorities in recent years, so many regional school networks have been able to deepen their cooperation with Russia. Schools and municipalities in Eastern Finland, with their close proximity to Russia, have been especially active in such cooperation. Finland and Russia share about 180 twin towns between them, and cooperation in education between schools is often among their priorities. ${ }^{82}$ Many schools, municipalities and regions have benefitted from successful cooperation with their Russian counterparts, and many different separate

\footnotetext{
${ }^{80}$ Based on information received from the Secretariat of the National Board of Education. 81 ibid

${ }^{82}$ Aluehallintavirasto (2010) "Venäjä-yhteistyö"; Association of Finnish and Regional Authorities "Twin towns of Finland”; National Board of Education, Finland “Opetushallituksen jakama valtionavustus koulujen kansainvälistymiseen lukuvuodelle 2007-2008".
} 
projects are well worth mentioning.83 A Finnish school also exists in both Moscow and Saint Petersburg. ${ }^{84}$

\subsection{Iceland}

\subsubsection{General framework}

The scale of bilateral cooperation between Iceland and Russia in education and research is small; little formal cooperation exists between Icelandic and Russian organisations in this field. Some bilateral agreements between ministries and institutions exist, but cooperation has been relatively inactive in recent years. Cooperation is often based on individual contacts. ${ }^{85}$

The Republic of Iceland established an agreement on Cooperation in the fields of Culture, Science and Technology with the Soviet Union on 25 April 1961; no other agreements in this field have since been established with the Russian Federation. According to the Icelandic Ministry of Education, Science and Culture, the agreement is inactive, although some form of cooperation related to student exchange is still practiced in the framework of this agreement (see below). At the moment, Iceland has no plans for any new state-level strategies with Russia in the field of education and research. ${ }^{86}$

\subsubsection{Cooperation in the field of education}

In general, all levels of education from compulsory to higher education actively participate in international cooperation. The Office of International Education (www.studyiniceland.is), supported by the Icelandic Ministry of Education, Science and Culture, promotes international educational cooperation on all levels of education. Many schools participate in European and Nordic programmes such as the Comenius programme and NordPlus Junior. As Russia is not among the programme countries, schools have no natural contacts or ways to cooperate with Russia. During the 2010 school year, one beginner-level course in Russian was offered at the upper-secondary school level as a distance education course. ${ }^{87}$

\footnotetext{
83 For more information on successful school cooperation with Russia, see the publication (2008) of the guide for internationalization of schools (in Finnish) at

www.cimo.fi/instancedata/prime.../15496_osaanko_uskallanko.pdf. For more information about challenges schools in Eastern Finland have encountered, have a look a study by Tanja Kemppi in Pentti Stranius (ed.) Oppia Rajalla (2007).

${ }^{84}$ Moskovan suomalainen koulu; Pietarin suomalainen koulu.

${ }_{85}$ According to several respondents.

86 Information from the Icelandic Ministry of Education, Science and Culture.

87 Based on information received from respondents.
} 
According to Icelandic law number 63/2006, higher education institutions are encouraged to engage in international cooperation. Universities and research institutes administer their international cooperation independently. With regard to cooperation in higher education with Russia, the University of Iceland has bilateral agreements with the Plekhanov Russian Academy of Economics and the Moscow State University. The agreement with Plekhanov is mainly for student exchanges, but thus far no Russian students have come to Reykjavik through that agreement. A couple of Icelandic students have participated in an exchange study period in Moscow at the Plekhanov Russian Academy of Economics. The other agreement with the Moscow State University is a one-way agreement for Russian language students from the University of Iceland. The department of Russian studies also engages in some cooperation with the Saint Petersburg State University. 88

The University of Akureyri, Bifröst University and the University Center of the West Fjords participate in the North2North student exchange and mobility programme offered by the University of Arctic. Several Russian universities also participate in the North2North programme, so student exchanges are also possible through this programme. ${ }^{89}$

The Icelandic Ministry of Education, Science and Culture announces an annual call to foreign students for Icelandic Government Scholarships for Icelandic studies at the University of Iceland. The scholarship programme is also open to Russian students. Students from 27 countries are eligible to apply. The scholarships are intended for students of language and literature, with preference given to students with prior knowledge of Icelandic or other Nordic languages. The monthly scholarship is for a stipend of ISK 114000 (about EUR 700), and the programme covers the registration fees. According to information from the Icelandic Ministry of Education, Science and Culture, few applications come from Russia; indeed the last two calls saw no applications from Russian students. ${ }^{90}$ It is possible to study Icelandic at the Moscow State University, but currently Iceland has not sent an Icelandic lecturer to Moscow. ${ }^{91}$

Correspondingly, the Russian Federation state scholarship programmes for students from foreign countries have also been open to applications from Icelandic students and researchers. The quota for 2009-2010 was four grants for university education and three grants for a short stay of study or research. ${ }^{92}$

\footnotetext{
88 Based on information received from respondents.

89 University of the Arctic, "Where can I go?".

90 The Árni Magnù sson Institute for Icelandic Studies, “Icelandic government scholarships”, supplemented with additional information from the Ministry of Education.

${ }^{91}$ The Árni Magnùsson Institute for Icelandic Studies, "Icelandic lecturers abroad".

92 Ministry of Education, Science and Culture, Iceland "Styrkir til háskólanáms í Rússlandi".
} 
Although some exchange programmes between Iceland and Russia are available, mobility is inactive. Russia is not among the popular study destination countries for Icelandic students.

\subsubsection{Research cooperation}

No previously collected material on Icelandic-Russian research cooperation is available, and the general trend is that nobody knows about possible cooperation. The Icelandic Centre for Research, RANNIS, has no bilateral cooperation or agreements with Russian research agencies, and although little formal cooperation is based on agreements, some Russian involvement exists in academic and scientific projects in which Icelandic researchers participate. ${ }^{93}$ Cooperation in research could also be possible through the EU's FP7 programme.

According to the study on international cooperation in research among Nordic countries, some Icelandic-Russian cooperation occurs in research sectors, but the activity level is lower than in other Nordic countries. ${ }^{94}$ Some Icelandic researchers have various academic contacts with Russia, but such contacts are generally not institutionalised. While carrying out this study, a couple of researchers expressed the need for better resources to cooperate in research with Russians. Some researchers are engaged in area-based studies on Russia, whereas others are engaged in cooperation with Russian researchers in the field of Arctic studies, fishery science, marine biology or chemistry. ${ }^{95}$ The RussianIcelandic Institute of Renewable Energy (RIIRE) was established in Moscow in 2007 between the Moscow State Institute of International Relations (MGIMO University) and the School for Renewable Energy Science (RES) in Iceland, affiliated with the University of Iceland and the University of Akureyri. The future of the Institute and its activities in the fields of research and education, however, remain unclear as the RES is at least temporarily closed due to the financial situation in Iceland. ${ }^{96}$

Iceland has been active in the work of the Arctic Council and has assumed an active role in the establishment of the Council in the 1990s. Russia also participates in this regional cooperation; as noted in section 3.4, under Iceland's presidency of the Arctic Council in 2004, Iceland invited the ministers of education and research from eight Arctic counties to discuss future cooperation in this field. The scientific work of the Arctic Council is carried out in six working groups, two of which are

93 Information is based on several interviews

${ }_{94}$ Gunnarson Magnus (ed.), International Research Cooperation in the Nordic Countries. A publication from the Noria-Net. "The Use of bibliometrics in research policy and evaluation activities", pp. 18-22.

95 Information is based to several interviews.

${ }_{96}$ Russian-Icelandic Institute of Renewable Energy, supplemented with additional information. 
based in Iceland: CAFF (Conservation of Arctic Fauna and Flora) and PAME (Protection of the Arctic Marine Environment). ${ }^{97}$

\subsection{Norway}

\subsubsection{General framework}

Norwegian-Russian cooperation in education and research is highly developed and active; cooperation exists in many different fields of research and on all educational levels. In Norway, several agreements and strategies outline the aims of future cooperation. Ministries and state agencies are active cooperation developers, but operating institutions (schools, universities, research institutions) are themselves active developers of cooperation. Although many different educational and research institutes cooperate with Russia, cooperation abounds in Northern Norway, an area close to Russia. ${ }^{98}$

Several strategies and agreements institutionalise Norway's cooperation in education and research with Russia. Among the more important strategies are the Norwegian Government's High North Strategy (Regjeringens nordområdestrategi, 2006), ${ }^{99}$ its follow-up papers ${ }^{100}$ and its Strategy for the Internationalisation of Education in Norway (Internasjonalisering av utdanning, 2009), ${ }^{101}$ in which views the internationalisation of education from an overall perspective that includes all levels of education. The strategy states that "the internationalisation of education is something that concerns all pupils and students, training and teaching staff, and academic, administrative and technical personnel." ${ }^{102}$ The strategy also profoundly analyses cooperation with Russia in education and research. With regard to the High North Strategy, Stoltenberg's second government defined Northern areas as strategically important and facilitated opportunities in many fields, not only in research and education. Cooperation with Russia holds a special position, and as part of the strategy, cooperation has taken many forms as various ongoing activities. Some of these educational and research activities fall under the Barents 2020 project. 103

\footnotetext{
${ }^{97}$ Arctic Council, "Working groups", supplemented with additional information from the Arctic Council secretariat; Ministry for Foreign Affairs, Iceland, "Regional Issues"; Ministry for Foreign Affairs, Iceland, "Regional Cooperation".

98 Based on interviews and observations.

${ }_{99}$ Ministry of Foreign Affairs, Norway (2006) The Norwegian Government's High North Strategy.

100 Ministry of Foreign Affairs, Norway "Nordområdeportalen”.

101 Ministry of Education and Research, Norway (2009a) St.meld. nr. 14 (2008-2009) Internasjonalisering av utdanning.

102 Ministry of Education and Research, Norway (2009b) "Summary in English: Report No. (2008-2009) to

the Storting, Internationalisation of Education in Norway”, pp. 3.

103 Ministry of Foreign Affairs, Norway (2007) "Samarbeid med Russland i nordområda".
} 
The agreement between Norway and Russia in the fields of culture, education and research was signed on 24 October 1994. Although cooperation exists in all educational fields, cooperation with Russia is the most intense in the field of higher education and research. These areas have or will have bilateral agreements with Russia. During Russian President Medvedev's visit to Oslo in April 2010, a cooperation agreement in education was signed. The present agreement strives for the improvement and development of cooperation in higher education, higher specialist education and in the field of continued education; it aims to give new impulse to bilateral cooperation. The parties to the agreement try to create conditions for constructive and long-term cooperation; the agreement includes, among other things, the following activities: educating specialists and continuing the education of scientific-pedagogical employees, strengthening and developing direct partnerships between institutions, developing joint programmes and projects, promoting the exchange of students and scientific-pedagogical staff, encouraging the exchange of experiences and information on higher education, maintaining databases and information networks, and promoting the study of both parties' language and culture. The agreement also includes specific measures for exchanges (described below). ${ }^{104}$ Also, during the same state visit, an agreement on research cooperation in the field of hydrometeorology was signed. ${ }^{105}$ The general agreement in the field of scientific cooperation, signed on 26 May 1998, expired a few years ago, and the process for establishing a new agreement is currently underway. ${ }^{106}$

\subsubsection{Cooperation and exchange programmes in the fields of higher education and research}

The above-mentioned "white papers" have defined many channels for cooperation, and many programmes aim to promote bilateral cooperation. Considerable emphasis has fallen on exchange programmes, but other types of funding mechanisms for cooperation are also available. Some of the programmes focus only on Russia, whereas other programmes include even other programme countries.

Different agencies administer the programmes. The Norwegian Centre for International Cooperation in Higher Education (SIU) (www.siu.no), a public Norwegian agency that promotes international cooperation in education, coordinates the following programmes relating to Russia: the Fellowship programme for Studies in the High North,

104 Ministry of Education and Research (2010) Avtale mellom Kunnskapsdepartementet i Kongeriket Norge og Utdannings- og vitenskapsministeriet i Den Russiske Føderasjon om utdanningssamarbeid.

105 Ministry of Education and Research, Norway, "Bilateralt samarbeid".

106 Ministry of Education and Research, Norway, "Bilaterale forskningavtaler", supplemented with interview data. 
the Scheme for Norwegian Studies abroad, the Quota Scheme and, together with the Research Council of Norway (www.forskningsradet.no), the Cooperation Programme with Russia 2007-2010. In addition to the numerous research programmes described in greater detail below, the Research Council of Norway coordinates the Yggdrasil grants for research stays in Norway. The Norwegian Barents Secretariat (www.barents.no), formed in 1993, promotes the development of Norwegian-Russian relations in the north. On behalf of the Norwegian Ministry of Foreign Affairs, the Secretariat funds approximately 200 bilateral Norwegian-Russian cooperation projects annually, including educational projects from primary-school level to university cooperation. The Secretariat has delegated coordination of the BarentsPlus programme to the Finnmark University College, which also coordinates the North2North scholarships of the University of the Arctic.

The Fellowships programme for Studies in the High North is already in its second programme period of 2010-2013. The programme is funded by the MFA, and is among the High North strategy activities. Seven institutions of higher education in the North, including the University of Nordland, Harstad University College, Narvik University College, Finnmark University College, Sami University College, the University of Troms $\varnothing$ and the University Centre at Svalbard, can apply student quotas from SIU and recruit students through the institutions. The programme is open to citizens of Canada, the USA and Russia. Students from Russia receive a minimum of $50 \%$ of all scholarships, about 70 of which are granted annually. Students from the BA to PhD level can apply for scholarships for one or two semesters of study on topics of High North relevance. The other activities of the programme include the mobility of teachers and staff from participating Norwegian institutions to partner institutions in Canada, the USA or Russia. ${ }^{107}$

The Norwegian Government's High North strategy has already expressed its desire to see the number of Russian students recruited through the quota scheme (kvoteordningen) increase. For the academic year 2009-2010, the quota for Russian students was 133, of which 54 were BA students, $56 \mathrm{MA}$ students and $23 \mathrm{PhD}$ students across all disciplines. In a nutshell, the quota scheme provides financial support to study toward a full degree in Norway and benefits about 1100 students from developing countries in the South as well as countries in the Western Balkans, Eastern Europe and Central Asia. Students are expected to return to their home countries after completing their degree in Norway. If they do not return, they must repay the loan according to the same system as Norwegian students. The programme aims to contribute to competence building through education; the target country benefits

${ }^{107}$ Norwegian Centre for International Cooperation in Higher Education (SIU) “Nord områdestipend”, supplemented with information from the SIU. 
from the educated students when they return to their home countries. This programme is not constricted to institutions in North Norway; rather, all HEIs in Norway are eligible to apply for quotas. ${ }^{108}$

The Cooperation Programme in Higher Education and Research between Norway and Russia for the years 2007-2010, coordinated by the SIU and the Research Council, included 15 projects, all of which received long-term funding for cooperation. The programme was one of the priorities mentioned in the High North strategy for enhancing cooperation between Norwegian and Russian institutions in the fields of higher education and research in areas relevant to the High North. Seven of the projects were higher education projects, and eight were research projects. The eligible activities included research cooperation, cooperation based on the Bologna process goals - including the development of joint programmes, the exchange of researchers, the establishment of networks, and the organisation of events (seminars, conferences and workshops). The total budget for the programme period was NOK 48000 000. A new cooperation programme for cooperation with Russia in higher education is currently underway with the SIU and Ministry of Foreign Affairs of Norway. Although no detailed information is available at this time, the plan is to be a five-year programme that would cover the whole of Russia. More information on the programme will be available by the summer of 2011.109

The SIU is also coordinating the Scheme for Norwegian studies abroad (Norgekunnskap). The budget in 2010 for activities concerning Russia was NOK 1463 500, financed by the Ministry of Foreign Affairs of Norway. The general aim of the programme is to support Norway's positive image and to provide teaching services and lecturers for foreign institutions of higher education that teach Norwegian language and cultural studies. The programme also targets foreign students studying Norwegian-related subjects to come to complete part of their studies in Norway. 110

The Norwegian research council coordinates the Yggdrasil mobility programme, which offers grants to international $\mathrm{PhD}$ students and young researchers for one- to ten-month research stays in Norway. About 50 countries are eligible for these grants. For the academic year 2009-2010, Russian students received 12 of 155 grants, and for the academic year 2010-2011, Russian students received 6 of 97 grants. Until recently, the Yggdrasil mobility programme has had no special focus on

\footnotetext{
${ }^{108}$ Norwegian Centre for International Cooperation in Higher Education (SIU) “Kvoteordningen", supplemented with additional information from the SIU.

${ }^{109}$ Norwegian Centre for International Cooperation in Higher Education (SIU), "Cooperation programme with Russia 2007-2010", supplemented with additional information from the SIU, the Research Council and Ministry of Education and Research, Norway.

110 Norwegian Centre for International Cooperation in Higher Education (SIU), "Scheme for Norwegian studies at higher education institutions abroad", supplemented with additional information from the SIU.
} 
Russia, but the call in 2011 has targeted Russia to increase the mobility of researchers in the fields of mathematics, the natural sciences and engineering. The grants earmarked for these fields are part of the PETROMAKS programme priorities (more about the PETROMAKS programme below). ${ }^{111}$ The objective of the programme is to promote the internationalisation of Norwegian research and to make Norway an attractive research destination for highly qualified international $\mathrm{PhD}$ students and younger researchers in all subject areas, thus strengthening the Norwegian research communities involved.112

One of the programme priorities of the Norwegian Barents Secretariat is competence, including funding for education projects, but not for cooperation in research. This paragraph describes only cooperation in higher education funded by the Secretariat; school cooperation is described below in its own section. One of the main education projects is Barentsplus, an exchange programme for students and teacher exchanges between institutions of higher education in the Russian and Norwegian Barentsregion. The programme has been ongoing since 1995. Approximately 70 to 80 student exchanges and 15 to 20 teacher exchanges are financed annually. Scholarships are granted to institutions, and part of the scholarships, in addition to exchanges, can be used in other kinds of educational cooperation, such as translating joint Russian/Norwegian research and development products and contributing to Russian and Norwegian language courses. The main objectives of the programme will remain unchanged for the next few years. The programme is coordinated by Finnmark University College. 113

Norwegian institutions in the North are generally active in cooperation with the University of the Arctic. Finnmark University College also administers the North2North programme. The Norwegian Ministry of Education distributes funding to North2North mobility between University of the Arctic partner institutions in Russia and Norway. ${ }^{114}$

Although this study does not specifically examine cooperation related to training in the field of business, it is worth noting that Norway and Russia participate in a joint "Presidential Programme". In the framework of this programme and agreement, young Russian business managers carry out internships in Norwegian companies. Every year, Norwegian

\footnotetext{
111 Research Council of Norway, "Yggdrasil - young guest and doctoral researchers' annual scholarships for investigation and learning" and Research Council of Norway (2010e), "The PETROMAKS programme contributes additional funding for researchers from Brazil and Russia".

112 Research Council of Norway,"Yggdrasil - young guest and doctoral researchers' annual scholarships for investigation and learning".

113 The Norwegian Barents Secretariat, "Guidelines and Conditions", supplemented with additional information from the Norwegian Barents Secretariat; Barentsplus, "Welcome to the BarentsPlus Programme site", supplemented with additional information from the administration of the programme.

114 Based on different interviews.
} 
employees are invited to Saint Petersburg to participate in a course on "Doing Business in Russia".115

The agreement on education cooperation between Norway and Russia, signed in April 2010, also describes different forms of cooperation. These include lifelong learning or training for an annual maximum of 15 Russians to Norway and 15 Norwegians to Russia for study purposes. The parties have also agreed to organise training in Russian and Norwegian languages in institutions of higher education. ${ }^{116}$ The Norwegian Ministry of Education and Research finds that existing programmes already cover most of the activities and measures concerning the mobility of Russian students and teachers to Norway. 117 The Embassy of the Russian Federation in Oslo has yet to update new information on their website concerning possible new actions for Norwegian students or teachers to Russia in the framework of the new education agreement. However, cooperation in the framework of the agreement signed in 1994 includes scholarships for students and teachers to study in language courses in Russia. 118

Norway has elected not to participate in the Tempus cooperation under the European Union's education programmes, and it is generally unknown whether Russian partners participate in the same Erasmus Mundus projects under Action 1, in which Norwegian institutions may participate.

\subsubsection{Bilateral cooperation and mobility statistics among institutions of higher education}

Taking into account all the above-mentioned programmes, it is quite natural for many institutions of higher education, especially those in the North, to engage in plenty of cooperation with Russia. Cooperation with universities in Murmansk and Arkhangelsk has traditionally been important, but geographical cooperation has extended to Saint Petersburg, Moscow, Komi and Siberia. ${ }^{119}$ This section rephrases the cooperation in some of these institutions and also presents the latest statistics for student exchanges between both countries.

Several universities or university colleges in Norway have established bilateral cooperation with Russian universities. The university deserving of special recognition for its bilateral cooperation is the University of Nordland (www.hibo.no), formerly Bodø University College which was

\footnotetext{
115 http://www.nho.no/the-presidential-programme/ny-norsk-russisk-avtale-article22039-365.html 116 Ministry of Education and Research, Norway Avtale mellom Kunnskapsdepartementet $i$ Kongeriket Norge og Utdannings- og vitenskapsministeriet $i$ Den Russiske Føderasjon om utdanningssamarbeid.

117 Based on information from the Ministry of Education and Research, Norway.

118 Embassy of the Russian Federation in Oslo, "SAMARBEIDSPROGRAM innen kultur, utdanning og forskning mellom Regjeringen i Den Russiske Føderasjon og Regjeringen i Kongeriket Norge”.

${ }_{119}$ According to information received from the SIU.
} 
upgraded to university status on 1 January 2011. Bodø University College has engaged in cooperation with Russian institutions of higher education since 1991 and has contributed to the education of about 4000 Russian students in the fields of economy and administration. Many Norwegian students have participated in an exchange period in Russia through Bodø University College's several cooperation channels. Bodø University College has also cooperated with universities in Saint Petersburg and administers a joint degree programme with the Moscow State Institute in International Relations (MGIMO University). Cooperation with Pomor State University has also been active and has included projects in the field of social work. Bodø University College currently offers a degree programme for Bachelor of Circumpolar Studies, and a programme for Master in Arctic Social Work is currently under development. Some of the Bodø University College's Russia activities are funded through the Norwegian government's Barents 2020 programme. 120

The Sámi University College in Kautakeino, Norway, is an institution of higher education for indigenous research and Sámi culture, language and way of life. It serves all Sámi students in the Sámi area of Norway, Sweden, Finland and Russia, but few of these students are from Russia. The Sámi University College has also administered a project on reindeer husbandry targeted towards Russian indigenous people.121

Another form of university cooperation worth noting is the Norwegian University Centre in Saint Petersburg (www.st-petersburg.uio.no). The cooperation is administered by the University of Bergen, the University of Oslo, the University of Troms $\emptyset$ and the Norwegian University of Science and Technology in Trondheim (NTNU). The Centre in Saint Petersburg was opened in 1998 and has received funding from the Norwegian Ministry of Foreign Affairs and the Norwegian Research Council, but it is now financed by the four founding universities. The Centre's annual budget is about NOK 3.5 million. The centre organises Russian courses for students from these four universities, as well as courses in other subjects. About 80 Norwegian students participate in the courses in Saint Petersburg annually, and the Centre hosts also hosts about 100 students from all across Scandinavia on a short-term basis. It also assists Norwegian and Russian researchers in establishing contacts and hosts researchers from Norway. ${ }^{122}$

Newspapers reported a boom of Russian students in Norway in the autumn of 2010; the number of Russian students had increased 33\% from 2009 to 2010. In 2010, Russian citizens for the first time constitut-

\footnotetext{
120 BarentsObserver.com (2010a) “New University in Northern Norway”; University of Nordland (2009) "Bodø University College and Russian Northern Area University in Arkhangel offer combined teaching"; Ministry of Education and Research, Norway, St.meld. nr. 14, pp. 53. 121 Sámi University College, "Sámi University College - the Sámi guiding star".

122 According to information on the Centre's website, supplemented with additional information from the Centre.
} 
ed the largest foreign student group in Norway. ${ }^{123}$ The years leading up to this saw this number rise steadily. In 2000, the number of Russian students was 190, in 2005 it was 663 students in 2005, and in 2010 it was 1035 students. These numbers include Russian citizens with permanent residency in Norway, as well as all Russian exchange and degree students to Norway. The statistics also include Russian students registered in e-based and distance study programmes administered by Norwegian institutions of higher education. Thus, not all students included in the statistics necessarily reside in Norway, even though they are included in the statistics. ${ }^{124}$

The number of Norwegian students in Russia is low, comprising about 110-150 students in recent years. Thus, mobility between Russia and Norway appears unbalanced. And although the above-mentioned statistics may not include the short-term Norwegian students attending the Norwegian University Centre in Saint Petersburg, only nine Norwegian degree students were in Russia in 2008-2009.125

\subsubsection{Research cooperation}

Norway has a long tradition of bilateral research cooperation with Russia in the fields of marine research, environmental research, polar research and energy research. ${ }^{126}$ The High North strategy and in its followup papers prioritise all these fields of study. Russia is one of the ten most important partners for Norway in research cooperation. As noted above, the state-level agreement on research and technology which expired a couple of years ago is currently under revision. In June 2009, the Research Council of Norway (RCN) and the Russian Academy of Sciences (RAS) signed a joint declaration of intent regarding cooperation in the area of science and technology. The Norwegian Research Council is also working on bilateral agreements with Russian research foundations, including the Russian Foundation for Basic Research and the Russian Foundation for Humanities. This broad cooperation includes annual Arctic Offshore Workshops between the RCN and the RAS. The Research Council of Norway participates in the ERA.Net RUS programme (more information in the section on EU-Russia cooperation). ${ }^{127}$

The Norwegian Research Council administers research programmes involving significant cooperation with Russia or with a focus on Russia.

\footnotetext{
123 BarentsObserver.com (2010b) "Russian student boom in Norway”.

124 Norwegian Centre for International Cooperation in Higher Education (SIU), Mobiletsrapport 2009, page

27 , supplemented with additional information from the SIU.

125 Ibid

126 Research Council of Norway (2010d) "Russia".

127 Research Council of Norway (2010c) "Norwegian-Russian workshop", a presentation by Siri Helle

Friedemann "Norwegian and Russian cooperation"; Research Council of Norway (2010b), "Good neighbourly

relations and mutual interests: Russia - an increasingly important research partner for Norway", supple-

mented with additional information from the Research Council.
} 
Among these programmes are the NORRUSS programme on Russia and international relations, as well as the PETROMAKS and the PETROSAM programmes, of which Russia is one of the programmes' target countries. The PETROMAKS programme prioritises the following fields of research: environmental technology for the future; exploration and reservoir characterisation; enhanced recovery; cost-effective drilling and intervention; integrated operations and real-time reservoir management; sub-sea processing and transportation; deepwater, sub-sea and arctic production; gas technology; and health, safety and the environment. The programme also cooperates with Russian partners having signed a cooperation agreement with the Russian Academy of Science's Institute for Oil and Gas and having established cooperation with several Russian universities and institutions. Such cooperation includes 17 ongoing projects (and three alreadycompleted projects) which arrange field trips, workshops and conferences, and training for Russian and Norwegian MA and PhD students, as well as contribute to joint publications. ${ }^{128}$

The Research Council has developed a new NORRUSS programme entitled "Russia and International Relations in the Northern Areas", which aligns neatly with the government's High North strategy as well as the Research Council's own Research Strategy for the Arctic and Northern Areas (forskning.nord). The programme's primary objective is to generate knowledge relevant to Norwegian foreign policy, the expansion of international relations in the north, and Norwegian-Russian trade and industry. The programme is social science-oriented and aims to expand knowledge in Norway of Russia's social conditions, economy, trade, management of natural resources and environment. The programme includes both basic research as well as industry-oriented research. The NORRUSS is not a cooperation project which would specifically promote institutional building with Russian research institutes, but is rather a research programme for Norwegian research institutions. ${ }^{129}$

Several research institutions drive research cooperation with Russia. In addition to the Institute of Marine Research, the Institute for Nature Research, the Norwegian Meteorological Institute (which signed the bilateral cooperation agreement with Russia), the Norwegian Polar Institute and the infrastructure in Svalbard are important arenas for international cooperation in the High North. Several Russian students have carried out studies in Svalbard and have used the above-mentioned grants.

The ongoing social sciences-oriented research with a focus on Russia is carried out by the Norwegian Institute of International Affairs in cooperation with the Graduate School of Business, the University of Nordland and Lillehammer University College; the Fridtjof Nansen Institute in

128Ibid, Research Council of Norway,"Optimal Management of Petroleum Resources, PETROMAKS".

129 Research Council of Norway (2010a) "Enhancing Norwegian-Russian cooperation: Strengthening social

science research on Russia", supplemented with additional information from the Research Council. 
cooperation with the University of Troms $\emptyset$ and the Peace Research Institute; and the Norwegian Institute for Defence Studies, in cooperation with the Universities of Oslo and Tromsø, as well as the Fridtjof Nansen Institute.

\subsubsection{Cooperation in other fields of education}

Although research and HEI cooperation with Russia has been thoroughly described earlier, important cooperation has also taken place among schools. The scale, however, is smaller and is concentrated predominantly in the Northern parts of Norway, specifically in the County of Finnmark. The High North strategy includes school cooperation in Finnmark and describes it as a case study in the strategy for the internationalisation of education. The exchange of pupils and teachers is viewed as fostering cross-border friendship, understanding and mutual learning. The opportunity to learn each other's languages is also an important factor. ${ }^{130}$ In general, relatively few pupils in Norway study Russian as a foreign language. Only four schools (three in Finnmark, one in Tromsø) teach Russian language, starting in the eighth class; on the uppersecondary level, only eight schools offer Russian as foreign language. These schools are located in Finnmark, Troms, Buskerud, Vestfold, Akerhus, Oslo, Bergen and Trondheim. ${ }^{131}$

The cooperation strategy of the Education Department of the County of Finnmark with north-western Russia summarises the priorities of the programme period 2006-2010. Among these priorities were the following: using ICT in cooperation activities, raising the awareness of environmental matters and using art and culture in schools. During 2008-2009, 49 projects from primary to upper-secondary schools received funding. Previous programmes were carried out in 1999-2002 and 2003-2005, and the cooperation will continue after 2010. In fact, the new strategy for 2011-2013 is currently under preparation by the Education Department of the County of Finnmark, and the Norwegian Ministry of Education and Research will continue to provide financial support for the cooperation projects. Their annual budget is about NOK 2 million. The County of Finnmark and the Government of Murmansk Region are also in the process of establishing a cooperation agreement for the coming years. ${ }^{132}$

In addition, the Norwegian Barents Secretariat has funded several school cooperation projects as well as some projects coordinated by folk high schools (folkehøgskole) in the northern parts of Norway. Although

130 Ministry of Foreign Affairs, Norway, The Norwegian Government's High North Strategy, page 33.

131 Based on information received from the Fremmespråkssenteret.

132 Fylkesmanne i Finnmark, "Strategiplan 2006-2010. Samarbeid med Nordvest-Russland", supplemented

with additional information from the Ministry of Education and Research and from the Fylkesmannen i

Finnmark. 
such cooperation with Russia in the field of adult education is not particularly institutionalised, the Norwegian Association for Adult Learning has, thanks to financial support from the Norwegian Barents Secretariat, carried out a preliminary project to map opportunities to establish a network between adult education organisations in northern Norway and those in north-western Russia.

The cooperation between the County of Akerhus and Russian education authorities also deserves mention, as this cooperation led directly to the establishment of an upper-secondary school in Moscow in 1994. The programme receives financial support from the Norwegian state budget. For the Russian side, the main idea was to create an arena for pedagogical research and development based on the Scandinavian model and to provide Russian youth access to the Norwegian and Western higher education systems. The Norwegian side emphasised opportunities for educational development and providing educated Norwegian youth with skills in Russian language and culture. The school can accept 20 Russian pupils and 15 Norwegian students annually, but rather few of the students come from Norway. 133

\subsection{Sweden}

\subsubsection{Current trends in cooperation}

Cooperation in education and research between Sweden and Russia has long traditions. Although Russia is not the most prioritised country for cooperation in education and research, different programmes benefitting from the support of the Swedish government have nevertheless developed cooperation in research and in many fields of education. In general, all Swedish governments since the collapse of Soviet Union have supported the Russian reform process, including the fields of education and research. Development aid has shifted to neighbouring country cooperation, which prioritises activities that provide mutual benefit for and promote mutual understanding of the countries' respective cultures. ${ }^{134}$

\footnotetext{
${ }^{133}$ Ministry of Education and Research, Norway, St.meld. $n r .14$, p. 31, supplemented with additional information from the Norwegian Ministry of Education and Research.

${ }^{134}$ Swedish International Development Cooperation Agency (2010b), "Vårt arbete i Ryssland". For more information on Swedish financial assistance to Russia after the collapse of the Soviet Union, see Ministry for Foreign Affairs, Sweden (2005), Strategi för utvecklingdssamarbetet med Ryssland 2005-2008 and a publication by Eduards Krister, Krivonos Michail, Rylander Lars, Det Svenska stödet till reformprocessen $i$ Ryssland 1991-2008, Stockholm: Sida. This publication provides a thorough analysis of the results of the 17 years of cooperation. In the fields of education and research, cooperation has focused on the development of research and educational capacity in Russia and the creation of long-term networks uniting research and educational institutions in Sweden and Russia. The cooperation has been managed through the Swedish Institute, and the projects were included in the larger framework of promoting democracy. The development programme between 1991 and 2008 also provided training in many other fields. For example, 100 unemployed Russians
} 
Since the end of the 2000s, some changes in the forms of cooperation in education and research have taken place. The Swedish Institute (SI), a public agency under the Swedish Ministry of Foreign Affairs, used to established agreements on cooperation in the fields of culture, education and science with the Soviet Union/Russia. These agreements included student and researcher exchanges, as well as participation in summer courses. ${ }^{135}$ Today, Sweden and Russia currently have no state-level agreement on cooperation in the fields of education and science. 136

In addition to SI and its Visby Programme for cooperation in education and research, Sida, the Swedish International Development Cooperation Agency, has also been involved in education, training and research cooperation with Russia. Sida, together with SI, coordinates the "Strategi för Sveriges stöd till demokrati och mänskliga rättigheter i Ryssland" for the years 2010-2013. Since 2005, Sida has had the Baltic Sea Unit in Visby, which aims to develop cooperation with neighbouring countries in the Baltic Sea area. Sida has provided funding for joint projects in the fields of civil security, the environment and energy as well as for joint projects related to important social and health issues. In the near future, Sida's Baltic Sea Unit will likely merge with SI, which could lead to more comprehensive Baltic Sea cooperation. The emergence of a new Baltic Sea organisation within SI would cover more target groups and the projects would align with the EU's Baltic Sea Strategy, the EU's Eastern partnership and its coming partnership with Russia. The Swedish Ministry for Foreign Affairs has already authorised parties to further plan possible solutions for the merger, and the government is likely to decide in May or June 2011.137

That said, cooperation in the fields of education and research will likely remain important in future programme also (see the Visby Programme's current activities, described below). In addition, this section presents educational activities in the new strategy "Strategi för Sveriges stöd till demokrati och mänskliga rättigheter i Ryssland". In recent years, the government of Sweden has also focused on some strategic issues in research on Russia, so this section also describes cooperation in research between Sweden and Russia, and provides an overview of the cooperation with Russia that institutions of higher education and

in the field of tourism received additional training as a result of a cooperative project between the University of Uppsala and the Technical University of Arkhangelsk. Bank employees have also received some training, as have women entrepreneurs and social workers. According to the publication (p. 92), this cooperation has included a large number of people from Sweden and Russia who have come to know each other: "En tidigare isolering har brutits. Där det tidigare fanns en smal kontaktyta med Ryssland, har Östbiståndet lyckats bygga upp kontakter på bredden."

135 Centre for International Mobility (2007) Conference on EU-Russian Higher Education Cooperation: Mobility of Students and Academic Staff, p. 53.

136 Based to information received from the Swedish Institute and the Swedish Ministry of Education and Research.

${ }^{137}$ Swedish International Development Cooperation Agency (2010c) "Östersjöenheten kastar loss från Sida", supplemented with additional information from the Swedish Institute. 
schools are engaged in. In general, internationalisation is considered important in all the fields of education and research in Sweden. All educational institutions benefit from international contact. Similar programmes, such as exchanges, study trips, educational projects and work practice, take place on all levels of education, from preschool to adult education. Student exchanges are naturally most common in the field of higher education. Bringing foreign teachers, researchers and students to Sweden for teacher/student exchanges is also considered important to the internationalisation of education. ${ }^{138}$

\subsubsection{The Visby Programme - the Swedish Institute's Baltic Sea Region Exchange Programme}

The Swedish Institute (SI) (www.si.se) is a public agency working in the field of public diplomacy. It aims to establish lasting cooperation with other countries through strategic communication and exchanges in the fields of culture, education, science and business. Its main activity in relation to education and research cooperation with Russia is the Visby Programme, financed by the Ministry of Foreign Affairs of Sweden, although SI has also contributed to the teaching of Swedish in Russia. Every year, about 800 students study Swedish in 20 Russian universities, located mainly in north-western Russia and Moscow. 139

Since its establishment in 1997, the Visby Programme has financed cooperation between hundreds of institutions and has granted scholarships to thousands of individuals. The purpose of the programme is to mutually develop cooperation in education and research between Sweden and the programme countries, which include Belarus, Estonia, Latvia, Lithuania, Poland, Russia and Ukraine. Of these seven countries, the programme prioritises Russia (the whole Russia is included from 2007), Ukraine and Belarus. Russia is the country with the highest number of selected projects. The programme is open to high schools, university colleges and universities. The Ministry for Foreign Affairs decided in 2010 to exclude the adult education component, partly because they wanted the programme to have a narrower focus. Either institutions or individuals can apply for scholarships or project funding. In the field of higher education and research, the forms of cooperation include: project funding, individual longterm grants and grants for short-term visits. On the upper-secondary school level, the programme supports mobility and exchange projects between Swedish and schools in the target country. The programme also organises several annual events connected to higher education, research

\footnotetext{
138 Ministry of Education and Research, Sweden (2009) From Preschool Pedagogy to Nanotechnology. Education and Research in Sweden, p. 9.

${ }^{139}$ For detailed information about the teaching of Swedish in these 20 Russian universities, see http://www.si.se/Svenska-spraket/Svenska/Svenska-spraket/Universitet-i-utlandet/Lasarsredogorelser/
} 
and innovation. For example, the Visby Programme, in cooperation with SSE Russia, organised a seminar with a focus on leadership in academic organisations in the countries of Belarus, Russia and Ukraine in autumn 2010. The Visby Programme's budget for 2011 is SEK 56447000.140 The possible merger of SI and Sida's Baltic Sea Unit will likely lead to changes in the Visby Progamme's specific calls described below.

\section{Scholarships in the fields of higher education and research}

Project funding is divided into grants for research and education cooperation for a period of one to two years with at least one partner outside of Sweden, and grants to organise conferences. Institutions can also apply for funding for short visits, such as project planning or contact visits. The objective for research cooperation is to strengthen the capacity to conduct collaborative research projects, to promote high-quality research in the region, to promote the dissemination of results and to support the development of methodology. The goal for the Visby Programme's educational cooperation is to strengthen the education systems of the region and to increase participating institutions' ability to administer educational projects. ${ }^{141}$

Individual long-term scholarships are open for students and researchers from Sweden to programme countries and from programme countries to Sweden. Scholarships for Swedish researchers and students to programme countries from all study areas are awarded for stays from one month to one year. ${ }^{142}$ Individuals are also welcome to apply for scholarships for shorter study or research stays of two to four weeks in programme countries. PhD students, researchers or teachers in Swedish institutions can also apply for scholarships to participate in conferences. Swedish institutions can also apply for financial support to invite researchers from programme countries to attend conferences in Sweden. ${ }^{143}$

Students and researchers from programme countries can also apply for scholarships to Sweden. The Master's scholarships are restricted to applications from Belarus, Russia and Ukraine. Subjects for which one can apply for scholarships range from gender studies to engineering. The competition in the most recent call was quite tight: 43 of 574 individuals received funding in 2010. About 40 scholarships will be offered for the academic year 2011-2012.144 The Visby Programme also offers scholarships for PhD studies and postdoctoral research in Sweden for a

\footnotetext{
${ }^{140}$ Swedish Institute (2010f) "Visbyprogrammet - Svenska institutets Östersjöprogram" and Swedish Institute (2010c) "Events", supplemented with additional information from the Swedish Institute.

${ }^{141}$ Swedish Institute (2010b) "Akademiska projektsamarbeten" and Swedish Institute (2010e) "Kontaktbesök och konferenser på akademisk nivå".

${ }^{142}$ Swedish Institute (2010a) "Akademiska långtidsstipendier".

143 Swedish Institute (2010e) "Kontaktbesök och konferenser på akademisk nivå".

${ }^{144}$ Study in Sweden, "Visby Program - Swedish Institute's Baltic Sea Region Exchange Program for master's

level studies in Sweden".
} 
period of six to twelve months. Both undergraduate and graduate students in Swedish language and literature are eligible to apply for scholarships covering one or two semesters. ${ }^{145}$ The Programme has for several years also funded the participation of undergraduate and graduate students as well as teachers from Russia, Belarus and Ukraine in summer courses organised at different universities in Sweden. More than 1000 people have benefitted from this opportunity to attend summer courses in Sweden. ${ }^{146}$

\section{Scholarships on the upper-secondary school level}

Schools can apply for funding in the framework of the Visby Programme for the planning of joint projects and for actual exchange projects which aim to stimulate long-term cooperation between upper-secondary schools in Sweden and those in other programme countries. All subjects are included. The scholarships are intended for the exchange of pupils, teachers and other school staff. 147

\subsubsection{Educational activities in Sweden's strategy to promote democracy and human rights in Russia for 2010-2013}

The government of Sweden has authorised Sida and SI to implement the strategy for the support of democracy and human rights in Russia for 2010-2013. Although the strategy mainly excludes education and research cooperation, a couple of activities nevertheless deserve mention. Financial assistance to the Moscow School of Political Studies will continue, as the strategy stipulates. Since 1997, Sida has provided the school with a total of SEK 15 million in funds. For many years, the school has educated academics, politicians and civil servants in various aspects of democracy. Although the strategy fails to specify other possible actions in relation to universities and training, among the most prioritised areas are issues related to media, gender and politics. The annual budget is about SEK 37 million, most of which goes mainly, though not exclusively, to north-western Russia. ${ }^{148}$

\subsubsection{Research cooperation}

To date, Sweden and Russia have no bilateral agreement in the field of research, although the government's strategy "Ett lyft för forskning och innovation" mentions that the government is open to further bilateral

\footnotetext{
145 Study in Sweden"Visby Program for students of Swedish language and literature".

146 Swedish Institute (2010g) "130 foreign students accepted to the Visby Program Summer University".

147 Swedish Institute (2010d) "Gymnasiesamarbeten".

148 Swedish International Development Cooperation Agency (2010a), "Moscow School stimulerar unga att

forma ett modernare Ryssland"; Ministry for Foreign Affairs, Sweden (2010) Strategi för stöd till demokrati

och mänskliga rättigheter i Ryssland under perioden 2010-2013.
} 
research agreements with other countries. ${ }^{149}$ Sweden has four state research agencies that fund research: Vetenskapsrådet (VR); Forskningsrådet för arbetsliv och socialvetenskap (FAS); Forskningsrådet för miljö, areella näringar och samhällsbyggande (Formas); and Verket för innovationssystem (Vinnova). The agencies have no bilateral agreements with Russia. VR's policy for bilateral agreements is that research cooperation is often managed most effectively on the level of individual researchers. Therefore the council does not, in principle, enter into any higher-level bilateral agreements. 150 At least VR and Formas have funded research projects related to Russia or which involve Russian participation. Formas has also cooperated with Russia in the framework of BONUS ERA-Net cooperation. ${ }^{151}$ With regards to FAS, the agency considers Russia an interesting partner, especially in the field of research on public health and welfare. ${ }^{152}$

Russia has been defined as one of the politically important geographical regions in the Swedish government's 2008 paper entitled "Ett lyft för forskning och innovation" (A boost for research and innovation). According to this paper, recent events have shown a need for analytical researchbased knowledge on development in Russia and its neighbour countries. Because Russia is an important neighbour country, understanding the kinds of changes that take place in the region, as well as the driving forces behind these changes and the impact they could have on Sweden is important. Questions related to the polar areas are also considered important, due to Russia's close proximity to Arctic. Such research must be carried out with a broad perspective ranging across the fields of economics, politics, cultural and religion studies, and sociology. Swedish research on Russia must maintain high quality and be well coordinated. According to the strategy, certain universities and university colleges should allocate more of their 2009-2012 resources to research and research training in politically important regions, including Russia. ${ }^{153}$ Related to the government's strategy, the Swedish Research Council announced a call for research on politically important geographical regions. ${ }^{154}$ This resulted in the establishment in January 2010 of the Uppsala Centre for Russian and Eurasian Studies (www.ucrs.uu.se). Besides research, the Centre is also designed to serve as a national resource centre. 155

As the study "International Research Cooperation in the Nordic Countries" shows, Russia is an important cooperation partner for Swedish re-

\footnotetext{
149 Ministry of Education and Research, Sweden (2008) Regeringens proposition 2008/09:50, Ett Lyft för forskning och innovation, p. 210.

150 Based on information received from VR.

151 Based on information from Formas. For more information about BONUS research cooperation, see section 3.5

152 Swedish Council for Working Life and Social Research.

153 Ministry of Education and Research, Sweden Regeringens proposition 2008/09:50, pp. 112-113, 239.

154 Swedish Research Council (2010), "Politically important geographic regions".

155 Uppsala University, "UCRS Uppsala Centre for Russian and Eurasian Studies".
} 
searchers. ${ }^{156}$ In addition to the newly established Uppsala Russia Centre, other institutions also focus significant resources on Russia. In 1994, the Swedish government established the Foundation for Baltic and East European Studies. The Foundation finances research carried out at Södertörn University and has established the following two institutions: the Centre for Baltic and East European Studies (www.sh.se/cbees) and the Baltic and East European Graduate School. In recent years, the foundation has granted about SEK 200 million to Södertörn University annually.157 The Stockholm Institute of Transition Economics at the Stockholm School of Economics, which focuses on questions concerning Eastern Europe and the former Soviet Union, has also carried out economic research projects with Russian counterparts with the support of the Swedish government's former development strategy for Russia. ${ }^{158}$ In addition, the Swedish Polar Research Secretariat, which the government's research strategy specifically mentions, has engaged in some cooperation with Russian researchers. ${ }^{159}$ Swedish-Russian researchers are also eligible to cooperate through the EU's FP 7 research programmes.

\subsubsection{Cooperation in the field of higher education and mobility statistics}

Several universities and university colleges cooperate with Russia, and cooperation with the Baltic Sea region is often part of their strategy for internationalisation. The International Programme Office for Education and Training has surveyed the connections HEIs have with Russia. Larger universities usually have bilateral agreements with Russia, whereas smaller universities and university colleges have fewer such agreements, and not all agreements are active. ${ }^{160}$ Lund University, for example, has had 14 agreements with Russia, but 8 of them have expired, and the rest are essentially inactive. ${ }^{161}$

Many respondents of this study have highlighted the Baltic University Programme (BUP) (www.balticuniv.uu.se), coordinated by Uppsala University, which administers an extensive network of approximately 225 universities and other institutions of higher education throughout the Baltic Sea region, including 20 Russian partner institutions. The BUP website states that "The Programme focuses on questions of sustainable development, environmental protection and democracy in the Baltic Sea

\footnotetext{
156 Gunnarson Magnus (ed.), International Research Cooperation in the Nordic Countries. A publication from the Noria-Net. "The Use of bibliometrics in research policy and evaluation activities", p. 24. 157 Östersjöstiftelsen.

158 Stockholm Institute for Transition Economics, "Russia and Eastern Europe"; Delegation of the European Commission to Russia (2009), Compendium on Science \& Research Cooperation between the European Union and the Russian Federation, p. 110.

159 Swedish Polar Research Secretariat (2010), "Tajmyr".

${ }^{160}$ Centre for International Mobility, Conference on EU-Russian, p. 40.

161 Based on information from Lund University.
} 
region. The aim is to support the key role that universities play in democratic, peaceful and sustainable development. This is achieved by developing university courses and by participating in projects in cooperation with authorities, municipalities and others". The programme is currently also a strategic partner of the Council of Baltic Sea States. ${ }^{162}$ No detailed information is available on double-degree programmes between Sweden and Russia, but at least one such programme exists. Jönköping University and the Moscow State University have a newly established doubledegree programme for a "Master of Science in International Business Development". ${ }^{163}$ The Stockholm School of Economics in Russia is also worth mentioning, for nowadays it has schools in both Moscow and Saint Petersburg. 164

Cooperation with Russia is also possible through the EU's Tempus and Erasmus Mundus programmes. Calls in 2008-2009 revealed a total of three funded Tempus projects with Swedish-Russian participation. In 2000-2005, Sweden participated in 14 Tempus projects with Russia. 165 Universities and university colleges are naturally active participants in Visby Programme activities as well.

Most student exchange mobility between Sweden and Russia takes place, for example, through the universities' bilateral agreements, Visby Programme scholarships and language courses for Swedish students majoring in Russian language and North2North exchanges. In addition, the Foundation for the Furtherance of Swedish-Russian Relations also grants scholarships to young Russian students for stays in Sweden. ${ }^{166}$ Oftentimes, exchange students are "free movers", meaning the exchange take place outside the exchange programme or bilateral agreement.

With regard to statistics, 251 Russian students studied in Sweden for the first time in the academic year 2008-2009, 123 of whom were exchange students and 128, "free movers". This number shows a significant increase over the corresponding figures for 2005-2006 (147 students). Other statistics include both first-year students and those who began their studies in Sweden earlier. For Russian students, this figure is 447 students, and also shows a gradual increased from the corresponding figures for 2004-2005. Statistics are also available on foreign students who have completed a degree in Sweden. Such figures for Russian students have been about 50 students annually in 2006-2009. An interesting question is: What will happen to the numbers of students from Russia to Sweden after the introduction of tuition fees. The number of

\footnotetext{
162 Baltic University Programme, "About BUP".

163 Jönköping University (2010a), "Double degree", and Jönköping University (2010b), "New double-degree Master Programme".

164 Stockholm School of Economics in Russia.

165 Centre for International Mobility, Conference on EU-Russian, p. 31, supplemented with additional infor-

mation from the International Programme Office for Education and Training.

166 Sverker Åströms Stiftelse för främjande av de svensk-ryska förbindelserna.
} 
Swedish exchange students to Russia has decreased significantly since 2004-2005, when the number was still about 140 students per year. In the academic year 2008-2009, the corresponding number was only 64 students. ${ }^{167}$ Students from the humanities (mainly Russian language) comprise the most popular field of study for an exchange to Russia. 168

\subsubsection{Regional and school cooperation}

The Swedish Association of Local Authorities and Regions is planning to carry out a quantitative study of twinning between Sweden and other countries. At the moment they offer no specific information on the number of twinnings of Swedish-Russian municipalities or regions. ${ }^{169}$ A hasty data search shows that several municipalities have twinnings with Russian towns in north-western Russia, especially in the Kaliningrad region (south of Sweden) and the Kola Peninsula (north of Sweden). Cooperation has included student and teacher exchanges with financial support from the Swedish Institute.

According to the statistics provided by the Swedish National Agency for Education, some students study Russian language at the uppersecondary school level. The scale, however, is small, and the agency has no special bilateral cooperation with Russia. ${ }^{170}$

Moscow has a Swedish school that also accepts Russian children with some kind of relationship to Scandinavia; the school receives Swedish state-funding for Swedish pupils. ${ }^{171}$ The International Programme Office for Education and Training administers an Atlas Programme for Cooperation and Practice in preschools, primary schools, upper-secondary schools and institutes for adult education. Russia, like all other countries in the world, is included in the programme area. ${ }^{172}$

\footnotetext{
167 Swedish National Agency for Higher Education (2010) "Internationell mobilitet i högskolan 2008/2009", pp. 32-46, 76, 82.

168 Centre for International Mobility, Conference on EU-Russian, p. 37.

169 Based on additional information provided by SKL.

170 Skolverket, "Betyg och studieresultat i gymnasieskolan läsår 2009/10", supplemented with additional information from the Agency.

171 Svenska Skolan i Moskva, supplemented with additional information from the school.

172 Internationalla Programkontoret, "Atlas".
} 



\section{Intergovernmental organisations in the region: cooperation in education and research}

The Nordic Council of Ministers (NCM), the Council of the Baltic Sea States (CBSS), the Barents-Euro Arctic Council (BEAC) and the Arctic Council (AC) are intergovernmental organisations covering largely the same geographical area with the same kind of activities, including education and research, although their resources for cooperation vary. The organisations meet regularly to develop interaction, coordinate regional measures and plan possible joint initiatives. The aim is to prevent unnecessary overlap, as well as to pave the way for possible synergies between the organisations' activities. ${ }^{173}$ The end of this section presents some other forms for regional cooperation as well.

\subsection{Nordic Council of Ministers}

\footnotetext{
Education has always been an important element in Nordic cooperation. By applying a wider geographical scope and involving neighbours, co-operation in education, research and innovation are seen to be the driving forces in sustaining the wider Baltic and Northern European region as internationally competitive, dynamic and attractive. ${ }^{174}$
}

The members of the Nordic Council of Ministers are Denmark, Finland, Iceland, Norway, Sweden and the autonomous territories of the Faroe Islands, Greenland and Åland. The NCM (www.norden.org) has long engaged in important cooperation and programmes with Russia. The NCM Information Office in Saint Petersburg was established as early as 1995, and the office in Kaliningrad was inaugurated in 2006. The NCM values close cooperation with Russia, especially with regions in NorthWest Russia, and aims to strengthen and develop the Baltic Sea region, considered a dynamic European region, by cooperating with Russia and

\footnotetext{
173 Nordic Council of Ministers (2008), The Nordic Region in an International Perspective, Nordic co-operation in a European Framework 2007, pp. 13, 25

174 Kononenko Vadim (2008) Norden's high five to the neighbourhood. Assessment of the Nordic Council of

Ministers offices in the Baltic countries and Northwestern Russia, p. 30.
} 
the Baltic States. Among the aims of cooperation with Russia are to promote democratic societal development, to initiate open and pluralistic relationships and to develop conditions for economic cooperation and trade. 175 The NCM also provides guidelines for cooperation with NorthWest Russia. ${ }^{176}$

The previous section described the bilateral cooperation Nordic countries have had with Russia in education and research. However, joint Nordic cooperation in education and research with Russia is also important for the individual Nordic countries, as such cooperation supplements national cooperation and brings added Nordic value. Joint Nordic cooperation programmes with Russia have operated since the 1990s. The Nordic Academy for Advanced Study (NorFA), a successor of NordForsk, opened its funding mechanism to Russian researchers, who were able to participate on equal terms in research networks, mobility and research training activities. According to the survey "Going Nordic", 28\% of NorFA-funded projects in 1999-2005 involved partners from Russia. ${ }^{177}$ In line with current developments in Nordic-Russian cooperation, NordForsk (www.nordforsk.org) has shifted towards supporting Nordic-Russian collaboration within fields of joint priority and with the aim of joint funding. Mainly, this has meant channelling Nordic-Russian seed money and network funds through existing Nordic Centre of Excellence programmes. Still, researchers from Russia also have the opportunity to participate in other NordForsk-funded activities, provided they can secure their own funding. ${ }^{178}$ In education and training, cooperation with North-West Russia and the Baltic States has taken place on the Nordic level through the Nordplus Neighbour programme (2004-2006), which aimed to develop long-term network cooperation. Another platform for Nordic-Russian cooperation has been the NCM Arctic Cooperation Programme, which has funded several projects pertaining to education and research in the Arctic areas. ${ }^{179}$

The NCM flagship in terms of cooperation with Russia today is the Knowledge Building and Networking Programme for cooperation with North-West Russia, which was launched in 2007 and continues through 2013. The programme focuses on promoting exchanges of knowledge, experience and skills, and aims to establish networks and long-term partnerships between Nordic and Russian organisations. Education, training and research are among the five programme areas of the entire

\footnotetext{
175 Nordic Council of Ministers, "Nordic co-operation with Russia", and Nordic Council of Ministers, The Nordic Region in an International Perspective, pp. 8, 45.

176 Guidelines for 2009-2013 are available at http://www.norden.org/en/nordic-council-of-

ministers/ministers-for-co-operation-mr-sam/russia/documents/guidelines-for-the-nordic-council-ofministers-co-operation-with-north west-russia.

${ }^{177}$ Aasland Aadne (2007), Development in Research, An Outline of the Science Systems in Russia and the Baltic

States, Oslo: NordForsk, p. 22; Aasland Aadne (2006) Going Nordic - A NordForsk user survey, p. 10.

${ }^{178}$ According to information received from NordForsk.

179 Nordic Council of Ministers "Nordic co-operation in the Arctic".
} 
programme. Related to this component, the NCM has been drafting priorities for future cooperation in education and research with Russia since 2006. Their meeting with Russian authorities in Saint Petersburg in 2006 and in Kaliningrad in 2007 revealed their mutual interest in advancing with joint cooperation. Since then, negotiations have progressed: the Ministry of Education and Science of the Russian Federation and the Nordic Council of Ministers plan to sign a memorandum of understanding on cooperation in education and research and to establish a joint cooperation programme. ${ }^{180}$

Among the NCM priorities is that the cooperation programme with Russia be long term. The NCM aims for the joint Nordic-Russian programme in education and research to be based on mutual interest, joint priorities, activities and steering as well as equally shared funding. Thus, the NCM also expects the Russian side to participate in funding the joint programme. With regard to the total budget of the programme, the financial resources serve more as seed funding for the cooperation. So for possibly larger initiatives, the programme will supplement national funding or financial possibilities through, for example, the EU. The NCM considers it important that the programme be jointly planned and based on common priorities. The programme is intended to cover research cooperation and all levels of education. The purpose is to establish three separate sub-programmes. For the first phase of this new foreseen Nordic-Russian cooperation, the main administrative coordinator on the Nordic side will be the Norwegian Centre for International Cooperation in Higher Education (SIU). SIU will also administer the sub-programme for higher education, which will be based on open calls and competition on the jointly defined themes. The programme for research will, on the Nordic side, be coordinated by NordForsk, and cooperation with Russia will fall on, for example, the Nordic Centres of Excellence, the eScience Initiative or the Nordic Top-level Research Initiative (TRI) on Climate, Energy and the Environment. For the planned cooperation in adult education and schools, which SIU will also administer and which will cover primary, upper-secondary and vocational levels, the plan for the first phase is to establish one or two joint Nordic-Russian projects on jointly defined themes. A joint Nordic-Russian conference on education and research is foreseen to be organised every other year. ${ }^{181}$

Prior to the establishment of a joint programme, the NCM has funded preparatory actions for research and education cooperation with Russia in the framework of the Knowledge Building and Networking Programme. Two calls for preparatory actions in education, including activi-

180 Nordic Council of Ministers "Nordic co-operation with Russia” and Nordic Council of Ministers (2010) The Knowledge Building and Networking Programme for co-operation with North-West Russia, supplemented with information from the NCM secretariat.

181 Based to information received from the NCM secretariat. 
ties in network activities, preparatory visits, contact seminars and preparatory studies between Nordic countries and North-West Russia, were announced in 2008 and 2009. One could also apply for funding to connect Russian participants to ongoing Nordplus cooperation activities. The Norwegian Centre for International Cooperation in Higher Education (SIU) administered the calls. Of the 84 applications, 32 projects received funding in the 2008 call, and 28 projects of the 65 applications received funding in the 2009 call. Most of the applications were from the field of higher education, but many schools also submitted applications, and Finnish actors have been especially active in applying for funding. The calls also included the concept of co-financing: $30 \%$ of co-financing was required. ${ }^{182}$ The requirement for co-financing has been linked to a possible decrease in the number of prospective applicants, but the idea behind co-financing is to intensify the groups and organisations involved and to ensure that mobility and cooperation is better planned and more competent in order to serve mutual networking needs. ${ }^{183}$

In the field of research, NordForsk administered the pilot funding for cooperation with Russia and in 2008-2009 channelled this funding through the Nordic Centres of Excellence. The funded actions of cooperation with Russia included laboratory visits, courses and onsite training for researchers involved in a Nordic Centre of Excellence on Molecular Medicine as well as Nordic-Russian network seminars on child welfare within the Nordic Centre of Excellence Programme on Welfare Research. In 2010, NordForsk invested funding for Nordic-Russian research cooperation in a Nordic Centre of Excellence within the Top-level Research Initiative on Climate, Energy and the Environment 2009-2014. The Toplevel Research Initiative comprises six sub-programmes: "Effect studies and adaptation to climate change", "Interaction between climate change and the cryosphere", "Energy efficiency with nanotechnology", "Interaction of large-scale wind power", "Sustainable biofuels", "CO2 - capture and storage" and three horizontal aspects, one of which is Arctic research. The development of collaboration with Russian partners is included in one of the Nordic Centres of Excellence under the subprogramme "Interaction between climate change and the cryosphere", which also has a strong Arctic focus as well as previously established contacts with Russian research institutions in the field. ${ }^{184}$

\footnotetext{
182 Norwegian Centre for International Cooperation in Higher Education (SIU) and Nordic Council of Ministers, "Cooperation with Northwest Russia in Education - Guidelines for applicants 2009", supplemented with additional information from the programme administration

183 Kononenko Vadim (2008) Norden's high five to the neighbourhood, p. 31.

184 Based to information received from NordForsk.
} 


\subsection{Council of the Baltic Sea States}

Education and culture are among the five priorities of the CBSS (www.cbss.org). In addition to the five Nordic countries and Russia, Estonia, Latvia, Lithuania, Germany, Poland and the European Commission are also members of the council. The Ministers of Education and Science from member states of the council have held high-level meetings on education and science cooperation in the region. CBSS and NCM also interact: cooperation between the organisation is developing constantly, and opportunities for joint initiatives and projects are under discussion. 185 One example is the EuroFaculty Pskov, in which the NCM also participates and to which it contributes financially.

The main activity of the CBSS in the field of education is the EuroFaculty project, currently based in Pskov, in Russia. Previous projects have been completed in Kaliningrad in 2000-2007 and in the Baltic States in 1993-2005. The concept of a EuroFaculty is expected to be successful in many different forums, and two studies have investigated it in depth. 186 The Ministry of Education and Science of the Russian Federation has also been interested in the concept and will assess whether it can be disseminated to other regions in Russia.

The first phase of the EuroFaculty Pskov runs from 1 January 2009 through 31 December 2011. The aim is to upgrade university education in business economics at the Pskov State Polytechnic Institute. The actions include curriculum development in line with the Bologna process, new teaching and examination methods, the creation of a quality assurance system, language training, improved library facilities and the establishment of a mobility scheme. In short, the aim is for economic studies to meet recognised international standards. EuroFaculty projects include the Lead Country and the Lead University. Sweden was appointed Lead Country, and after a competition, the Turku School of Economics was awarded the task of heading the consortium of six universities, including Roskilde University, Trondheim Business Schools, the University of Turku, Saint Petersburg State University and Stockholm School of Economics, Saint Petersburg office. All CBSS member states jointly finance the project, with additional support from the city of Hamburg, the NCM and the United Kingdom. 187

An independent assessment of the results thus far is currently ongoing and will be ready in the beginning of 2011. If the evaluation and assessment of the results will be positive, the project may continue for

\footnotetext{
185 Nordic Council of Ministers, The Nordic Region in an International Perspective, p. 25.

${ }^{186}$ See Kristensen Gustav S. (2010) Born into a Dream: EuroFaculty and the Council of the Baltic Sea States and Askeland Kjell (2009) Researching the EuroFaculty Project at IKSUR Kaliningrad, a contribution to Educational Development in Russia, available at https://www.cbss.org/Education-Culture/education-a-culture.

187 Council of the Baltic Sea States, "EuroFaculty Pskov", supplemented with additional information by the CBSS secretariat.
} 
three more years in 2012-2014. The possible continuation of the EF Pskov would ensure long-term results and sustainability. ${ }^{188}$

CBSS has also engaged in other activities in the field of education and research. One of the CBSS strategic partners is the Baltic University Programme, which is a regional university network based at Uppsala University. CBSS is also exploring other possible forms of cooperation in education with north-western Russia and Kaliningrad. At the moment, the CBSS governing board, the Committee of Senior Officials, has commissioned the CBSS Secretariat to explore whether and how the CBSS could support the possible formation of the Baltic Law Institute, which would be an indirect follow-up to the EuroFaculty Kaliningrad project. This project could also serve as a possible venue of cooperation with other stakeholders, including the NCM and the EU.189

\subsection{Barents-Euro Arctic Council}

Education and research cooperation in the Barents Euro-Arctic region has a long history, based mainly on bilateral agreements between institutions of higher education and regional and national authorities. ${ }^{190}$ With regard to the BEAC (www.beac.st) structure, one can say that education and research cooperation through BEAC does not enjoy the same resources as does cooperation through CBSS and the NCM. In general, BEAC work, which involves the five Nordic countries and Russia as well as the European Commission, is described from the point of view of limited financial and human resources, especially in its working group activities. The working group on education and research, established in the beginning of the 2000s, has not, according to the Finnish Arctic strategy, been among the more active groups. ${ }^{191}$ Toward the end of the 2000s, however, the working group has again become active.

The BEAC structure formed in close cooperation with the Barents Regional Council (BRC), uniting 13 counties of the BEAC region. Working groups functioned on both the BEAC and the BRC levels. In addition, the working groups are joint working groups for both the BEAC and the BRC. Joint working groups on education and research (JWGER) belong to this category. The new mandate for JWGER was adopted in May 2009. Petrozavodsk State University acts as a regional chair for the working group. ${ }^{192}$ The reactivation of the JWGER benefitted from strong support at the $12^{\text {th }}$ ministerial meeting of the BEAC in autumn 2009 in Mur-

\footnotetext{
188 Ibid

${ }^{189}$ According to information received from the CBSS secretariat.

190 The Kolarctic ENPI CBC. Programme 2007-2013, p. 11.

191 Ministry for Foreign Affairs, Finland (2010b), Finland's Strategy for the Arctic Region, pp. 39-40, 80

192 Barents Arctic-Euro Council, "Education and Research"; Barents Arctic-Euro Council, "Joint Working

Group on Education and Research".
} 
mansk. Furthermore, the meeting issued the following statement: "The Council calls for further strengthened cooperation in academic and research spheres and supports integration of the educational systems of the Members and internationalisation of their education and research environment, promotion of academic mobility programmes and implementation of joint educational projects in line with the objectives of the Bologna Process and for the purpose of preparing highly qualified specialists capable of working in globalised conditions. Additional efforts should be undertaken to make the region more attractive for students and researchers from the Members and other countries."193

Thus far, JWGER members have contributed to the development of international cooperation in academic and research spheres in the Barents-Euro Arctic region. The members have organised several events which have been open to researchers from the region. Thus far, however, the working group has financed its activities through the budgets of participating institutions. Efforts will be made to discover funding opportunities for joint projects and programmes. The statement mentions the ENPI CBC Kolarctic Programme in particular. The working group also aims to develop cooperation in education and research with organisations such as the Arctic Council, the Council of the Baltic Sea States and the Nordic Council of Ministers. ${ }^{194}$

\subsection{Arctic Council and cooperation in the Arctic region}

The Arctic Council is a forum for cooperation between national governments and indigenous people on questions such as sustainable development and environmental challenges facing the Arctic region. It comprises the five Nordic countries, Russia, Canada and the United States. The AC has no permanent secretariat or budget, which can be considered a potential weakness of its work, as it reflects the limited expert resources and scarcity of funds available to its working groups. ${ }^{195}$ The general work of the Arctic Council concentrates more on research questions than on education cooperation. Universities or research councils do not directly participate in the work carried out by the Arctic Council working groups as such, but rather individual scientists from various research institutes participate instead. Of its six working groups, the ones which are involved mostly in science include AMAP (Arctic Monitoring and Assessment Programme), CAFF (Conservation of Arctic Flora

\footnotetext{
193 Barents Arctic-Euro Council, "Meetings of the Barents Euro-Arctic Council", 12th BEAC Foreign Ministers Meeting in Murmansk 2009.

194 Barents Arctic-Euro Council, "Joint Working Group on Education and Research"; Barents Arctic-Euro Council, "Annual Reports of the Working Groups 2009".

${ }^{195}$ Ministry for Foreign Affairs, Finland (2010b), Finland's Strategy for the Arctic Region, pp. 37-38, 78-79.
} 
and Fauna), PAME (Protection of the Arctic Marine Environment) and SDWG (Sustainable Development Working Group). ${ }^{196}$

The Arctic Council has also opened a platform for educational cooperation in the Arctic between the eight member states, although, as an organisation, the Council itself has not directly provided resources for the educational cooperation. Nonetheless, AC member states have advanced cooperation in education and research in the Arctic during their AC chairmanships outside the general procedures of the Arctic Council. For example, Iceland, during its AC chairmanship in 2004, invited the Ministers of Education and Science of the Arctic Council Member States to a meeting in Reykjavik to discuss opportunities to strengthen cooperation in the areas of education and research in the Arctic. The Reykjavik Declaration highlights many important questions, such as the special need for a certain type of programme in education and science due to the vast geographical scope of the Arctic region and its dispersed populations. The Declaration also emphasised the importance of indigenous people's involvement in national and international research and scientific exchange programmes. The ministers agreed, on the basis of already existing national and regional programmes, to further explore opportunities for increased cooperation in the fields of education and science in the Arctic. ${ }^{197}$

The Arctic eight ad hoc working group in education and science, set up by the Ministries of Education and Research of the eight member states of the AC and coordinated by the NCM secretariat, continued the cooperation begun in Reykjavik between 2006-2008. The working group aimed to consider recommendations of the Declaration and to suggest possible platforms for collaboration. In fact, the group authored a long list of recommendations and suggestions for the cooperation discussed in the framework of the Reykjavik Declaration. The ad hoc group also suggested that intergovernmental meetings with Ministers of Education and Research from eight AC member states be organised every other year. ${ }^{198}$

One of the education and research forms of Arctic cooperation has been the University of the Arctic (UArctic) (www.uarctic.org), a cooperative network of institutions of higher education and other organisations in the North. The University of the Arctic will celebrate its $10^{\text {th }}$ anniversary year in 2011. Its member institutions, which currently including 126 institutions from eight Arctic countries and one institution from Scotland, share resources, facilities and expertise on higher education programmes relevant to Northern students. The University of the Arctic offers students of its member institutions a BA degree programme in

\footnotetext{
196 Based on additional information received from the Arctic Council.

197 Ministry of Education, Science and Culture, Iceland (2004), "Reykjavik Declaration", supplemented with

additional information from the Arctic Council.

198 Based on information received from the NCM.
} 
Circumpolar Studies, which includes courses on the land and environment, peoples and cultures, and contemporary issues of the Circumpolar World. North2North is the University of the Arctic's mobility programme. The University of the Arctic has received external funding from various sources, and ministries in different countries have also provided scholarships for North2North exchanges. ${ }^{199}$ The Northern Research Forum (www.nrfis) and annual Calotte Academy offer another platform to discuss actual Arctic questions.

\subsection{Examples of other regional forms of cooperation}

Besides the frameworks provided by bilateral cooperation, intergovernmental organisations working in the region or cooperation through the European Union, other ways to organise education and research cooperation in the region are also available. Two examples which combine cooperation in the Baltic Sea region are described below.

\subsubsection{UNESCO Associated School Project - Baltic Sea Project}

The UNESCO Associated Schools Project Network (ASPnet) is a global network of preschools, primary, secondary and vocational schools as well as teacher training institutions that work in support of international understanding, peace, intercultural dialogue, sustainable development and quality education in practice. More than 9000 educational institutions in 180 countries participate in the ASPnet, 200 of which the Baltic Sea Project (the BSP) (www.b-s-p.org/home) is a member. The BSP is cooperation project of about 200 schools from Denmark, Sweden, Finland, Russia, Estonia, Latvia, Lithuania, Poland and Germany that "seeks to raise the awareness of students on environmental problems in the Baltic region and to help them understand the scientific, social and cultural aspects of the interdependence of people and nature. Both in the classroom and in the field, students study water quality, coastal observation and environmental history." Annual events include training seminars for teachers and summer courses and forums for students. ${ }^{201}$

\footnotetext{
199 University of the Arctic, "BCS Core Courses"; University of the Arctic, "Where to go". Supplemented with interview data.

200Unesco, "The UNESCO Associated Schools Project Network".

201 Unesco, "Baltic Sea project"; Baltic Sea Project, "About BSP".
} 


\subsubsection{BONUS - cooperation of research funding organisations around the Baltic Sea area}

Today, ten research funding organisations around the Baltic Sea cooperate under the auspices of the BONUS Secretariat EEIG (www.bonusportal.org). This cooperation began back in 2003 under the Sixth Framework Programme BONUS ERA-NET for the years 2003-2008. The ERA-NET brought together key research funding organisations from all the EU member states around the Baltic Sea, including Russia. Ever since, the cooperation has continued. The BONUS+ programme for the years 2009-2011 received its funding from the research funding agencies in Denmark, Sweden, Finland, Estonia, Latvia, Lithuania, Poland and Germany. The Russian Foundation for Basic Research provides funding for Russian institutions that participate in BONUS+ projects. Negotiations with Russia are also ongoing about Russia joining BONUS EEIG. ${ }^{202}$

202 BONUS EEIG, "The Bonus Secretariat (EEIG). Baltic Organisations' Network for Funding Science EEIG" and BONUS EEIG, "Bonus ERA-NET". 


\section{Brief overview of EU-Russia cooperation in the field}

\subsection{General framework for cooperation}

In discussing the education and research cooperation between the Nordic countries and Russia, one cannot neglect cooperation executed on the EURussia level, as it provides an important and rather central framework for cooperation. Denmark, Finland and Sweden are member states of the EU, and Norway and Iceland also participate in several programmes of the EU through the EEA agreement, including the Seventh Framework Programme (FP7). The aim of this section is not to provide a deep analysis of the research and education cooperation executed on the EU-Russia level, as this could fill a separate study on that subject, but rather to examine the forms of cooperation on a general level, along with EU-Russia education and research activity especially relevant to Nordic countries.

There are many reasons why the EU finds cooperation with Russia important: to foster the political and economic stability of Russia; to maintain a stable supply of energy; and to cooperate in the fields of justice, home affairs, the environment and nuclear safety in order to prevent soft security threats. EU values also include the promotion of democracy, the rule of law and good governance, and respect for human rights and fundamental freedoms. Cooperation between the EU and Russia has in recent years developed towards a strategic partnership based on shared interests and common values. The Four Common Spaces was established in 2005 on mutual interest and cooperation. No longer is cooperation based on the roles of Donor (EU) and Recipient (Russia). As a result of Russia's significant economic development, the need for broad financial assistance from the EU has disappeared. Cooperation takes place on the basis of co-financing from the EU and Russia in order to meet the jointly agreed objectives of the Common Spaces. ${ }^{203}$

One of the Common Spaces is "Research, Education and Culture", which aims, among other things, to promote economic growth, to strengthen competitiveness, to optimise the link between research and the introduction of innovations, to stimulate close cooperation in the field of education, which includes greater integration in higher education

203 European Union External Action, "Russia" and European Union External Action, "Country Strategy Paper 2007-2013, Russian Federation." 
and greater research and academic mobility between the EU and Russia. ${ }^{204}$ To ease cooperation in this and other fields, the EU and Russia signed a visa facilitation agreement in 2007 which aims to facilitate the procedures for obtaining visas and waives visa fees for certain categories of people, including researchers and students.

EU-Russia cooperation in education and research in the framework of the fourth Common Space is implemented through at least the following cooperation programmes: the Seventh Framework Programme, Tempus, Erasmus Mundus, Northern Dimension, and the ENPI CBC programmes.

\subsection{Research cooperation}

EU-Russia cooperation in science has been described as a great success story: European and Russian scientists and research organisations have been working together in a variety of fields of science on either the European Community level or that of individual member states. Russia has been the most successful non-associated third-country partner in the activities of the Fifth, Sixth and Seventh Framework Programmes in terms of the total sum of financial contributions and the total number of participations. Agreements on cooperation in research exist in addition to the bilateral agreements which several EU member states already have with Russia. In the field of research, not only have the European Community and the Russian Federation had an agreement on scientific \& technological cooperation since 2000, which they most recently renewed in 2009, but the European Atomic Energy Community and the government of the Russian Federation have also benefitted from similar agreements in the field of nuclear safety and a separate agreement in the field of controlled nuclear fusion. Discussions have also begun in 2009 on Russia's potential association with the FP7, and negotiations continue to be one of the next steps in the joint agenda of the Fourth Common Space. ${ }^{205}$

In the framework of the agreement on scientific and technological cooperation, joint working groups comprising the thematic priorities of FP7 have been created. The working groups have been described as a good leap forward on the path towards more common research agendas. One of the outcomes of the working groups is the jointly coordinated calls. This essentially means that EU and Russian funding agencies have published parallel research calls with common research content and a requirement

204 Delegation of the European Commission to Russia (2009), Compendium on Science \& Research Cooperation between the European Union and the Russian Federation.

205 Delegation of the European Commission to Russia, "European Union-Russian Federation Scientific and Technological Cooperation, A Roadmap for Action 2009-2011”, p. 2, 27-29 and European Union External Action, "EU-Russia Common Spaces. Progress Report 2009", pp. 4, 45-48. 
to collaborate with Russian/EU research themes. Thus far, six such calls have taken place. One of the examples is a call in aerospace research in 2009. The budget of the call was EUR 8 million, which was co-funded equally by the EU and the Ministry of Industry and Trade of the Russian Federation. "These co-funded activities demonstrate that EU S\&T cooperation with Russia is moving towards a partnership between equals based on sharing funds and responsibilities, and that S\&T will play an important role in the recently launched EU-Russia Partnership for Modernisation", declares the Roadmap for EU-Russia research cooperation. ${ }^{206}$

At the moment, Russia can participate in the FP7 as a Third Country and an International Cooperation Partner Country. Thus far, the participation of Russian researchers in the FP7 has been strong: 323 Russian research organisations participate in about 190 granted projects which receiving about EUR 39.3 million in EU contributions. One of the FP7 sub-projects, "International Cooperation", focuses on supporting and stimulating the participation of third countries in the FP7 as well as providing opportunities for research programmes managed by third countries. This programme considers S\&T cooperation with Russia a long-term priority, and in order to support and develop the cooperation further, the programme currently funds four projects which involve or specifically target Russia. The programmes are the FP7 IncoNet EECA (VINNOVA of Sweden, the Research Council of Norway and the Academy of Finland are among the partners), BILAT-RUS, ACCESSRU and ERA.Net RUS, in which both the Academy of Finland and the Research Council of Norway participate. One of the aims of the ERA.Net Rus is to launch joint calls between EU countries and Russia. ${ }^{207}$

\subsection{Education cooperation}

Education cooperation between the EU and Russia is prioritised for the field of higher education and focuses on three broad topics: university cooperation and modernisation, academic mobility, and the promotion of multidisciplinary EU studies. ${ }^{208}$ Promoting the establishment of a European Higher Education Area (EHEA) and the Bologna process are naturally among the cornerstones of the cooperation. The Tempus and Erasmus Mundus programmes that apply to higher education cooperation with Russia are among the most important forms of this cooperation. One particularly important joint activity is the European Studies Institute in Moscow, which is co-financed by the EU and Russia.

\footnotetext{
206 Ibid

207 Ibid

${ }^{208}$ European Union External Action, "EU-Russia Common Spaces. Progress Report 2009", pp. 48-49.
} 
Tempus supports the modernisation of higher education in partner countries surrounding the EU, including Russia. The current Tempus IV runs from 2007 to 2013 and funds three types of activities, mainly through university cooperation projects: joint projects that support the modernisation of higher education institutions in the partner countries (e.g., curriculum development), structural measures that contribute to the development and reform of the higher education systems in partner countries, and accompanying measures comprising dissemination and information activities. Partner countries are permitted to define their national priorities, and funded projects are selected accordingly. Russian national priorities have focused on the modernisation of curricula, the ECTS system and the recognition of degrees, the development of lifelong learning in society, and qualification frameworks. In 2009, about EUR 10.2 million were distributed to funded Tempus projects with Russia, and a number of Russian universities have participated in Tempus projects since the beginning of the 1990s. ${ }^{209}$

Erasmus Mundus also operates in the field of higher education, and focuses in particular on academic mobility. The programme includes three actions, all of which Russia could basically participate in, but the most common actions with Russian participation are Actions 1 and 2. Since 2004, 340 Russian students have been selected to study in the Erasmus Mundus Joint Masters Courses available in Action 1. Erasmus Mundus Joint Doctoral Courses are quite a new form of cooperation, but Russian students holding a Master's degree can also apply for Joint Doctoral Courses. Action 2 of the Erasmus Mundus Partnership funds consortiums between certain partner countries, including Russia, and the European Union. Russian students can participate in exchange studies in European universities. Currently, the University of Turku in Finland leads a consortium with ten partner universities from Russia. ${ }^{210}$

The Lifelong Learning Programme, including sectorial subprogrammes for schools, higher education, vocational education and training, and adult education, has permitted third countries to participate in certain programme activities since 2010.211 More information about possible projects involving Russia is currently unavailable.

209 Ibid, Executive Agency, Education, Audiovisual \& Culture, "About Tempus IV" (2007-2013).

210 Delegation of the European Commission to Russia, "Higher Education"; Executive Agency, Education, Audiovisual \& Culture (2010a), "About Erasmus Mundus 2009-2013".

211 Based on information received from the Centre of International Mobility, Finland. 


\subsection{Regional EU-Russia cooperation - Northern Dimension and European Neighbourhood and Partnerships Instrument Cross-Border Cooperation}

One of the frameworks for education and research cooperation with the EU and Russia which is especially relevant to Northern Europe are the Northern Dimension, the EU's Baltic Sea Strategy and the Neighbourhood and Partnerships Instrument Cross-Border Cooperation (ENPI CBC) projects, which include the Kolarctic ENPI CBC Programme 20072013, the South-East Finland - Russia ENPI CBC Programme 2007-2013, the Karelia ENPI CBC programme and the Baltic Sea Region Programme 2007-2013.

The Baltic Sea Strategy is an internal EU strategy that is highly relevant to fostering innovation around the Baltic Sea Region, among other priorities, but also aims to develop external cooperation mainly through the Northern Dimension. ${ }^{212}$ The Northern Dimension (ND) is a common policy of four equal partners: the European Union, Norway, Iceland and Russia. The policy was drawn up as early as 1999 , but was revised in 2006. According to the new framework document, the Northern Dimension is a regional expression of the EU-Russia Four Common Spaces. Thus, education and research could also be relevant in terms of ND cooperation, but academic cooperation has thus far played no significant role in the four existing partnerships. ${ }^{213}$ A new initiative in this field has been the Northern Dimension Institute (NDI) (www.ndinstitute.org), established in 2009 and currently coordinated by the Lappeenranta University of Technology. The ND senior official and ministerial meeting have supported the idea of the Institute, which is an open network of universities and research institutes for the priority sectors of the ND policy. Some financing for the NDI has been provided from the Finnish Neighborhood area cooperation programme, but the NDI has thus far received no continuous basic funding for its operations. ${ }^{214}$

The funding instrument ENPI CBC (European Neighbourhood and Partnership Instrument Cross-Border Cooperation) strives to develop strategic partnerships between the EU and Russia in the four common spaces, thus education and research projects also receive funding. One of the ENPI CBC projects is the Kolarctic ENPI CBC 2007-2013 (www.kolarcticenpi.info), which includes the northern areas of Finland,

\footnotetext{
212 European Commission (2011b), "EU Strategy for the Baltic Sea Region".

213 European Union External Action, "Northern Dimension"; cf. Aalto Pami, Blakkisrud Helge, Smith Hanna (2009), "Policy recommendations for Northern Cooperation" in Aalto Pami, Blakkisrud Helge, Smith Hanna (eds) The New Northern Dimension of the European Neighbourhood.

${ }^{214}$ Northern Dimension Institute "NDI - Northern Dimension Institute", supplemented with information from the NDI secretariat.
} 
Norway, Russia and Sweden. The programme complements national cross-border cooperation and contributes to fulfilment of ND and Common Spaces objectives. The funding of the programme is provided by the EU, Finland, Norway, Sweden and Russia. The Russian Federation's Ministry of Regional Development provides Russia's co-financing portion, a financial contribution of about EUR 14.120 million for the programme period. It is based on the financial agreement between the EU and the government of Russia. 215

215 European Commission (2011a) "Cross-border cooperation (CBC)/ENPI Programmes"; the Kolarctic ENPI CBC Programme 2007-2013, supplemented with additional information from the programme secretariat. 


\section{Conclusion}

Appendix 2 presents a table that includes a simplified form the abovementioned bilateral forms of cooperation with Russia in education and research. Appendix 3 presents a selection of national and Nordic programmes with the following information: the name of the programme, the main funding organisation, the coordinator of the programme, the programme board/steering group, the main activities and volume of the programme.

All of the Nordic countries engage in some form of bilateral cooperation in education and research with Russia: some more (Finland and Norway), some less (Iceland). This study does not aim to analyse the specific reasons for these differences, but such cooperation clearly abounds in regions of geographical proximity to Russia. All the Nordic countries, except Sweden, have some kind of agreement which serves as a basis for their cooperation, often in the form of a cultural agreement that also covers education and research. In addition, Finland also has an S\&T agreement with Russia, and Norway an education agreement, although the latter country is also in the process of establishing an S\&T agreement with Russia. In addition, several operating institutions have their own bilateral agreements with their Russian counterparts. Finland and Norway have also identified Russia as a one of the priority countries in their programmes and strategies. In the case of Sweden, Russia is among the priority countries in its Visby Programme.

Compared to intergovernmental organisations, the resources channelled through the Council of the Baltic Sea States and the Nordic Council of Ministers have traditionally been greater than those channelled through BEAC and AC. The EU-Russia framework is also an important arena for cooperation, as all of the Nordic countries participate in the EU, either as member states or through the EEA agreement. Regional policies, such as the Northern Dimension and the ENPI CBC programmes as well as the Seventh Framework Programme and EU educational programmes, are significant for the Nordic-Russian perspective on education and research.

The Nordic countries usually assign geographical priority in cooperation to north-western regions in Russia, especially to the Murmansk, Arkhangelsk, Karelian, Leningrad and Kaliningrad regions. Cooperation also includes the Pskov and Novgorod regions, but on a smaller scale. Education and research institutes in the Murmansk, Arkhangelsk and Karelian regions tend to cooperate with the Nordic countries. Institutions in Saint Petersburg also engage in active cooperation with the Nor- 
dic countries, but they benefit from many international contacts and cooperation with a variety of countries. However, geographical coverage has broadened to include many other areas in Russia, and obviously, cooperation with institutions in Moscow is equally important. A new tendency in national programmes, including the Swedish Visby Programme and the Norwegian Cooperation Programme for Higher Education, has been to include the whole of Russia in the programme area.

Cooperation in research and higher education certainly abounds compared to other levels of education, as better resources of cooperation are available in these two fields, and research institutes and HEIs are able to use many state-level programmes - available chiefly in Norway and Finland, but also in Sweden - to fund their cooperation with Russia. However, institutions of research and higher education also use their own resources to develop cooperation with Russia. State-level programmes for cooperation often offer researcher, teacher and student exchanges, joint projects, the establishment of networks, funding to complete a degree, language courses, and other benefits. The CBSS EuroFaculty programme has already been carried out in Kaliningrad, and now contributes to curriculum development in the Pskov region. In the field of education, several disciplines are engaged in cooperation with Russia, but at least one field enjoys active cooperation with Russia in all of the Nordic Countries: university-level Russian language and culture studies. One interesting fact related to language cooperation is that Denmark, Finland, Norway and Sweden all provide resources for Russian HEIs to teach their languages in an effort to promote their cultures and languages in Russia.

Many mobility programmes are available in the field of higher education. These programmes, often funded by the Nordic countries, also offer scholarships for Russian students to come and study in Nordic countries. Thus far, Russia has provided scholarships for citizens of the Nordic Countries as a part of the larger Russian Federation Scholarship Programme for foreign citizens. Looking at the mobility statistics for Finland, Norway and Sweden, for example, a clear tendency emerges indicating that more Russian students come to study in these countries than Finnish, Norwegian and Swedish students go to Russia. Thus, the mobility between Nordic countries and Russia is unbalanced. Some Nordic countries have already attempted to discover reasons for this imbalance, but a deeper analysis of the subject is needed. An interesting case study would also involve the introduction of tuition fees and its possible influence on students from Russia.

Research cooperation with Russia takes place across a variety of fields of research, but what is interesting is that both Sweden and Norway have in recent years launched calls to fund multidisciplinary research projects focussing on Russia and providing more information on processes that take place in that country. Finland has been funding such 
research since the 1990s. Research cooperation also takes place through EU cooperation, and Arctic research is also considered important.

The cooperation that occurs on the school level (including primary, upper-secondary schools and vocational schools) should not be underestimated, especially in Northern Norway and Eastern Finland, where plenty of schools actively cooperate with Russia, although funding resources to support this cooperation are smaller. Forms of cooperation often include the exchange of pupils and teachers. Sweden, Norway and Finland have their own cooperation programmes in this field and even arrange seminars on the topic. Another important framework is municipal cooperation through twin towns: many twin towns are engaged in educational cooperation and activities with their Russian counterparts. For example, two cities in Denmark with Russian twin towns support school cooperation with Russia. Adult education is the most unstructured field involved in cooperation with Russia. Some individual projects have taken place, but such cooperation is poorly systematised, and state programmes pay little attention to cooperation with Russia in this field.

It appears that bilateral cooperation will continue at approximately the same volumes in the near future. Neither Iceland nor Denmark plan to pursue new state-level strategies for cooperation in education or research with Russia. Finland, Norway and Sweden, in contrast, will maintain approximately the same forms of cooperation in education and research with Russia in the near future, and no major cutbacks or significant new initiatives have been reported. The Nordic countries' national, bilateral cooperation with Russia is usually funded either by the Ministry of Education and Research or the Ministry for Foreign Affairs, respectively.

In general, Russia's growing economic strength and general development have changed the rhetoric of cooperation: the nature of cooperation with Russia has shifted from assistance programmes to one emphasising mutual understanding and joint programme priorities, which raises questions of joint, shared funding. In the field of research, Russia has already participated in the costs of joint international research projects; it has funded its share of the costs of joint research projects with, for example, the Academy of Finland. The Research Council of Norway will likely launch joint calls with Russian funding agencies in future. In addition, EU-Russia cooperation has seen joint research calls with shared funding, and the Ministry of Industry and Trade of the Russian Federation has provided funding for this purpose. In the joint ENPI CBC projects, the Russian Ministry of Regional Development has provided Russian national funding for cooperation. Naturally, shared funding in joint cooperation programmes will be a crucial question in future. Russia may understandably not be interested in participating in the costs of programmes that promote the teaching of Danish, Finnish, Norwegian or Swedish in Russian institutions of higher education, but plenty of topics represent shared Nordic-Russian priorities that could be equally funded 
in the forms of joint cooperation programmes. As the national, intergovernmental and EU levels already have plenty of actors, the focal question is whether programmes with Russia should merit more coordination. On the Nordic level, this study has shown that plenty of cooperation with Russia already exists on the national, bilateral level, and that this cooperation with Russia is important. Thus, cooperation in education and research with Russia is certainly a topic strongly deserving of further development on the Nordic level. 


\section{References}

Electronic materials have been accessed 1 February 2010 - 31 January 2011.

Aalto Pami, Blakkisrud Helge and Smith Hanna (2009) "Policy recommendations for Northern Cooperation", in Aalto Pami, Blakkisrud Helge, Smith Hanna (eds) The New Northern Dimension of the European Neighbourhood, Brussels: Centre for European Policy Studies. Online. Available http://www.ceps.eu/book/new-northerndimension-european-neighbourhood

Aasland Aadne (2006) Going Nordic- A NordForsk user survey, Oslo: NordForsk. Online. Available http://www.nordforsk.org/pubinfo.cfm?pubid=50

Aasland Aadne (2007) Development in Research. An Outline of the Science Systems in Russia and the Baltic States, Oslo: NordForsk. Online. Available www.nordforsk.org /_img/nordforsk_pb1_web.pdf

Academy of Finland, Research Collaboration with Russia. Online. Available http://www.aka.fi/Tiedostot/Tiedostot/Julkaisut/tiedeyhteisty\%C3\%B6\%20Ven \%C3\%A4j\%C3\%A4_sivuttain.pdf

Aluehallintavirasto (2010) "Venäjä-yhteistyö". Online. Available http://www.avi.fi/ fi/virastot/pohjoissuomenavi/kvyhteistyo/Sivut/Ven\%C3\%A4j\%C3\%A4\%E2\%80 \%93yhteisty\%C3\%B6.aspx

Arctic Council, "Working groups”. Online. Available http://arctic-council.org/ section/working_groups

Association of Finnish and Regional Authorities "Twin towns of Finland". Online. Available http://wwwold.kuntaliitto.fi/skriptit/kv-asiat/yk/selaa.asp

Baltic Sea Project, “About BSP”. Online. Available http://www.b-s-p.org/about/

Baltic University Programme, "About BUP”. Online. Available http://www. balticuniv.uu.se/index.php/about-us

Barents Arctic-Euro Council, "Annual Reports of the Working Groups $\rightarrow 2009$ ". Online. Available http://www.beac.st/?DeptID=8737

Barents Arctic-Euro Council, "Education and Research". Online. Available http://www.beac.st/?DeptID=8557

Barents Arctic-Euro Council, "Joint Working Group on Education and Research". Online. Available http://www.barentsinfo.fi/beac/document_database/ wg_documents.aspx?ID=8

Barents Arctic-Euro Council, "Meetings of the Barents Euro-Arctic Council $\rightarrow 12$ th BEAC Foreign Ministers Meeting in Murmansk $2009 \rightarrow$ Joint Communique of the 12th Ministerial Session". Online. Available http://www.beac.st/in_English/ Barents_Euro-Arctic_Council/Barents_Euro-Arctic_Council/Ministerial_meetings.iw3

Barents Cross Border University, "Barents Cross Border University (BCBU)". Online. Available http://bcbu.oulu.fi/

BarentsObserver.com (2010a), "New University in Northern Norway”. Online. Available http://barentsobserver.com/index.php?id=4849221\&xxforceredir=1\&noredir=1

BarentsObserver.com (2010b) "Russian student boom in Norway". Online. Available http://barentsobserver.com/index.php?id=4814213\&xxforceredir=1\&noredir=1

Barentsplus, "Welcome to the BarentsPlus Programme site". Online. Available http://www.barentsplus.hifm.no/

Belov Valeriy (2005) "Problems of the establishment and implementation of the academic mobility concept in Russia" in Pursiainen Christer and Medveded Sergey (eds.) The Bologna Process and its Implications for Russia, RECEP: Russia. Online. Available http://www.recep.ru/files/publ/bologna_en.pdf 
BONUS EEIG, "Bonus ERA-NET". Online. Available http://www.bonusportal.org/about_bonus/bonus_era-net

BONUS EEIG, “The Bonus Secretariat (EEIG). Baltic Organisations' Network for Funding Science EEIG". Online. Available http://www.bonusportal.org/about_bonus/ bonus_eeig

Centre for International Mobility (2007) Conference on EU-Russian Higher Education Cooperation: Mobility of Students and Academic Staff, Helsinki: CIMO.

Centre for International Mobility (2010a) CIMO korkeakoulutuksen kansainvälistäjänä 2009. Online. Available http://www.cimo.fi/instancedata/prime_product_ julkaisu/cimo/embeds/cimowwwstructure/15462_Cimo_korkeakoulujen_ kansainvalistajana_09.pdf

Centre for International Mobility (2010b) "Kindred Nations' Scholarships for FinnoUgrian minorities in Russia". Online. Available http://www.studyinfinland.fi/ tuition_and_scholarships/cimo_scholarships/kindred_nations

Centre for International Mobility (2010c), Kansainvälinen liikkuvuus yliopistoissa ja ammattikorkeakouluissa 2009. Online. Available http://www.cimo.fi/instancedata/ prime_product_julkaisu/cimo/embeds/cimowwwstructure/17967_kv-liikkuvuus_ korkeakouluissa_2009.pdf

Centre for International Mobility (2010d), Kansainvälinen liikkuvuus ammatillisessa koulutuksessa 2009. Online. Available http://www.cimo.fi/instancedata/prime_ product_julkaisu/cimo/embeds/cimowwwstructure/17964_kv-liikkuvuus_ ammatillisessa_koulutuksessa_2009.pdf

Centre for International Mobility (2011a) “Cimo Fellowships”. Online. Available http://www.studyinfinland.fi/tuition_and_scholarships/cimo_scholarships/cimo_ fellowships

Centre for International Mobility (2011b) "CIMOn talvikoulu”. Online. Available http://www.cimo.fi/ohjelmat/apurahat/jatko_opiskelu_ja_tutkimusapurahat suomeen/cimon_talvikoulu

Centre for International Mobility (2011c) “FIRST". Online. Available http:// www.cimo.fi/ohjelmat/first

Centre for International Mobility (2011d) “Korkeakoulujen Venäjä-yhteistyö kasvoi FIRST-ohjelmassa". Online. Available http://www.cimo.fi/ajankohtaista/ 101/1/korkeakoulujen_venaja-yhteistyo_kasvoi_first-ohjelmassa

Centre for International Mobility (2011e)“Tuloksia”. Online. Available http://www.cimo.fi/ohjelmat/first/tuloksia

Centre for International Mobility (2011f) "Venäjän valtion apurahat”. Online. Available http://www.cimo.fi/ohjelmat/apurahat/apurahat_korkeakouluopintoihin_ulkomaille/ venajan_valtion_apurahat

Council of the Baltic Sea States, "EuroFaculty Pskov". Online. Available https://www. cbss.org/Education-Culture/eurofaculty-pskov

Cross-Border University, "Study programmes”. Online. Available http://cbu.fi/en/ ohjelmat/

Danish Agency for International Education (2010a) "Cultural Agreements". Online. Available http://en.iu.dk/grants-and scholarships/cultural-agreements

Danish Agency for International Education (2010b) "International Cooperation and Mobility". Online. Available http://en.iu.dk/cooperation-and-mobility

Danish Agency for International Education (2010c) Mobilitetsstatistik for de videregående uddannelser 2008/09. Online. Available http://www.iu.dk/publikationer/ 2010-1/mobilitetsstatistik-for-de-vidergaaende-uddannelser-2008-09/ mobilitetsstatistik-for-de-videregaaende-uddannelser-2008-09/

?searchterm=mobilitetsstatistik

Danish Agency for International Education (2010d) "Rusland". Online. Available http://www.iu.dk/programmer-og-tilskud/hele-verden/kulturaftaler/andrelande/rusland 
Danish Agency for International Education (2010e) "Russia”. Online. Available http://en.iu.dk/grants-and scholarships/cultural-agreements/non-eu-countries/russia Danish University and Property Agency (2010) "Lecturer scheme”. Online. Available http://www.ubst.dk/en/international-cooperation/lektoratsordningen

Danmark evalueringsinstitut (2003) Den internationale dimension i folkeskolen. Online. Available http://www.eva.dk/projekter/2002/evalueringen-af-deninternationale-dimension-i-folkeskolen/projektprodukter/den-internationaledimension-i-folkeskolen/download

Delegation of the European Commission to Russia (2009) Compendium on Science \& Research Cooperation between the European Union and the Russian Federation. Online. Available ec.europa.eu/research/iscp/pdf/russia.pdf

Delegation of the European Commission to Russia, "European Union-Russian Federation Scientific and Technological Cooperation. A Roadmap for Action 2009-2011". Online. Available http://ec.europa.eu/research/iscp/pdf/russia_roadmap_20092011.pdf

Delegation of the European Commission to Russia, "Higher Education". Online. Available http://ec.europa.eu/delegations/russia/eu_russia/fields_cooperation/ higher_education/index_en.htm

Eduards Krister, Krivonos Michail and Rylander Lars (2009) Det Svenska stödet till reformprocessen I Ryssland 1991-2008, Stockholm: Sida, 2009. Online. Available www.sida.se/Global/.../Europe\%20incl.../SIDA48576sv_Ryssland_91-08.pdf

Embassy of the Russian Federation in Oslo, "SAMARBEIDSPROGRAM innen kultur, utdanning og forskning mellom Regjeringen i Den Russiske Føderasjon og Regjeringen i Kongeriket Norge". Online. Available http://www.norway.mid.ru/edu/ state_grants.html

European Commission(2011a) "Cross-border cooperation (CBC) / ENPI Programmes". Online. Available http://ec.europa.eu/europeaid/where/neighbourhood/ regional-cooperation/enpi-cross-border/programmes/index_en.htm

European Commission (2011b) "EU Strategy for the Baltic Sea Region”. Online. Available http://ec.europa.eu/regional_policy/cooperation/baltic/

European Union External Action, “Country Strategy Paper 2007-2013. Russian Federation." Online. Available http://ec.europa.eu/external_relations/russia/docs/ 2007-2013_en.pdf

European Union External Action, "EU-Russia Common Spaces. Progress Report 2009”. Online. Availble http://eeas.europa.eu/russia/docs/commonspaces_ prog_report_2009_en.pdf

European Union External Action, “Northern Dimension”. Online. Available http://www.eeas.europa.eu/north_dim/index_en.htm

European Union External Action, "Russia”. Online. Available http://www. eeas.europa.eu/russia/financial_cooperation_en.htm

Executive Agency, Education, Audiovisual \& Culture (2010a) "About Erasmus Mundus 2009-2013”. Online. Available http://eacea.ec.europa.eu/erasmus_mundus/ programme/about_erasmus_mundus_en.php

Executive Agency Education, Audivisual \& Culture (2010b) "Tempus Selection Results". Online. Available http://eacea.ec.europa.eu/tempus/results_compendia/results_en.php

Executive Agency, Education, Audiovisual \& Culture (2011) "About Tempus IV (2007-2013)”. Online. Available http://eacea.ec.europa.eu/tempus/programme/ about_tempus_en.php

Finlex (1992) “Asetus Venäjän kanssa yhteistyöstä kulttuurin, opetuksen ja tieteen alalla tehdyn sopimuksen voimaansaattamisesta". Online. Available http:// www.finlex.fi/fi/sopimukset/sopsteksti/1992/19920100

Fylkesmannen i Finnmark, "Strategiplan 2006-2010. Samarbeid med NordvestRussland". Online. Available www.fylkesmannen.no/Strategiplan_Nordvest_Russland_NkctO.pdf.file, 
Gunnarson Magnus (ed.), International Research Cooperation in the Nordic Countries. A publication from the Noria-Net. "The Use of bibliometrics in research policy and evaluation activities". Oslo: NordForsk. Online. Available www.nordforsk.org/ _img/bibliometri_1.pdf

Internationalla Programkontoret, "Atlas". Online. Available http://www. programkontoret.se/sv/Program-Stipendier/Program1/Atlas/

Jönköping University (2010a) “Double degree”. Online. Available http://hj.se/jibs/ en/education/double-degree.html

Jönköping University (2010b) "New double-degree Master Programme”. Online. Available http://hj.se/jibs/en/about-us/press/press-releases/archive/3-12-2010new-double-degree-master-programme.html

Ketels Christian (2010) Global Pressure - Nordic Solutions? Nordic Globalization Barometer 2010, Copenhagen: Nordic Council of Ministers. Online. Available http://www.norden.org/sv/publikationer/publikationer/2010-714/ at_download/publicationfile

Kononenko Vadim (2008) Norden's high five to the neighbourhood. Assesment of the Nordic Council of Ministers offices in the Baltic countries and Northwestern Russia. Copenhagen: Nordic Council of Ministers. Online. Available http://www.norden. org/en/publications/publications/2008-721/at_download/publicationfile

Memorandum (2010) - VIII Session of the Danish-Russian Intergovernmental Council on Economic Cooperation. Online. Available http://www.ambmoskva.um.dk/ NR/rdonlyres/35DDA998-77AD-4EED-A363-987BD56E51A7/0/ img11915400001.pdf

Ministeriet for Videnskab, Teknologi og Udvikling (2007) Internationalisering af universitetsuddannelserne. Online. Available http://www.ubst.dk/publikationer/ internationalisering-af-universitetsuddannelserne-marts-2007-1/ Internationalisering_komplet.pdf

Ministry for Foreign Affairs, Finland (2009) Russia Action Plan. Online. Available http://formin.finland.fi/public/download.aspx?ID=42535\&GUID=\{448538DABD92-4814-9B57-3590FB386721\}

Ministry for Foreign Affairs, Finland (2010a) "Finland's cooperation with neighbouring areas" . Online. Available http://formin.finland.fi/public/default.aspx? nodeid $=34823 \&$ contentlan $=2 \&$ culture $=$ en-US

Ministry for Foreign Affairs, Finland (2010b) Finland's Strategy for the Arctic Region. Online. Available http://formin.finland.fi/public/download.aspx? ID=63213\&GUID $=\{1 \mathrm{~F} 62 \mathrm{D} 138-\mathrm{C} 785-4 \mathrm{D} 4 \mathrm{C}-8 \mathrm{~EB} 7-531 \mathrm{~A} 7 \mathrm{C} 23 \mathrm{E} 5 \mathrm{FA}\}$

Ministry for Foreign Affairs, Finland (2011a) "Suomen lähialuyeyhteistyö" $\rightarrow$ Suomen ja Venäjän lähialueyhteistyön toimintaohjelma vuosiksi 2009-2011 and Lähialueyhteistyö. Online. Available http://formin.finland.fi/public/ default.aspx?nodeid=34823\&contentlan=1\&culture=fi-FI

Ministry for Foreign Affairs, Finland (2011b) Suomen ja Venäjän välinen lähialueyhteistyö vuosina 2004-2009. Online. Available http://formin.finland.fi/public/ download.aspx?ID=69892\&GUID $=\{54 C 459 A A-2 B 5 E-454 D-A A 36-98 E 13 D 462212\}$

Ministry for Foreign Affairs, Iceland, "Regional Cooperation". Online. Available http://www.mfa.is/foreign-policy/environment/regional-cooperation/

Ministry for Foreign Affairs, Iceland, "Regional Issues". Online. Available http://www.mfa.is/foreign-policy/regional-issues/

Ministry for Foreign Affairs, Iceland, "The Nature of Nordic Cooperation". Online. Available http://www.mfa.is/foreign-policy/nordic-cooperation/nature/

Ministry for Foreign Affairs, Sweden (2005) Strategi för utvecklingdssamarbetet med Ryssland 2005-2008. Online. Available http://www.regeringen.se/sb/d/108/a/50397

Ministry for Foreign Affairs, Sweden (2010) Strategi för stöd till demokrati och mänskliga rättigheter i Ryssland under perioden 2010 - 2013. Online. Available http://www.regeringen.se/sb/d/1390/a/11507 
Ministry for Foreign Affairs, Sweden (2011) "Ryssland". Online. Available http://www.regeringen.se/sb/d/5472/a/43790

Ministry of Education and Culture, Finland (2003) Suomi, Venäjä ja kansainvälinen yhteistyö. Opetusministeriön toimintaohjelma 2003-2007. Online. Available http://www.minedu.fi/OPM/Julkaisut/2003/suomi_venaja_ja_kansainvalinen_yhte istyo_opetusministerion_toi

Ministry of Education and Research, Norway (2009a) St.meld. nr. 14 (2008-2009) Internasjonalisering av utdanning. Online. Available http://www.regjeringen.no/nb/dep/kd/dok/regpubl/stmeld/2008-2009/stmeldnr-14-2008-2009-.html

Ministry of Education and Research, Norway (2009b) "Summary in English: Report No. (2008-2009) to the Storting. Internationalisation of Education in Norway".

Ministry of Education and Research, Norway (2010) Avtale mellom Kunnskapsdepartementet i Kongeriket Norge og Utdannings- og vitenskapsministeriet i Den Russiske Føderasjon om utdanningssamarbeid.

Ministry of Education and Research, Norway, "Bilaterale forskningavtaler". Online. Available http://www.regjeringen.no/nb/dep/kd/tema/forskning/ internasjonalisering-av-forskning/forskningsavtaler.html?id=495515

Ministry of Education and Research, Norway, "Bilateralt samarbeid". Online. Available http://www.regjeringen.no/nb/dep/kd/tema/internasjonalt_samarbeid_om_utdannin g_og/bilateralt-samarbeid.html?id=86757

Ministry of Education and Research, Sweden (2008) Regeringens proposition 2008/09:50. Ett Lyft för forskning och innovation. Online. Available http://www.sweden.gov.se/ $\mathrm{sb} / \mathrm{d} / 10003 / \mathrm{a} / 113957$

Ministry of Education and Research, Sweden (2009) From Preschool Pedagogy to Nanotechnology. Education and Research in Sweden. Online. Available http://www.sweden gov.se/sb/d/574/a/131020

Ministry of Education and Science and State University - Higher School of Economics (2007) OECD Thematic Review of Tertiary Education. Country Background Report for the Russian Federation. Online. Available http://www.oecd.org/dataoecd/22/ 10/40111027.pdf

Ministry of Education and Science, Russian Federation (1992) ЗАКОН РОССИЙСКОЙ ФЕДЕРАЦИИ "Об образовании". Online. Available http://mon.gov.ru/dok/fz/ obr/3986/

Ministry of Education and Science, Russian Federation (1996) ФЕДЕРАЛЬНЫЙ ЗАКОН "О высшем и послевузовском профессиональном образовании". Online. Available http://mon.gov.ru/dok/fz/obr/3993/

Ministry of Education and Science, Russian Federation (2006) “О федеральной целевой программе "Исследования и разработки по приоритетным направлениям развития научно-технологического комплекса России на 2007 - 2012 годы". Online. Available http://mon.gov.ru/dok/prav/nti/4418/

Ministry of Education and Science, Russian Federation (2009a) Международные соглашения о научно-техническом сотрудничестве. Online. Available http://mon.gov.ru/ files/materials/6668/ms-prizn.pdf

Ministry of Education and Science, Russian Federation (2009b) Международные соглашения о сотрудничестве в сфере образования. Online. Available mon.gov.ru/files/ materials/6668/ms-obraz.pdf

Ministry of Education and Science, Russian Federation (2010a) "Attracting leading scientist to Russian universities". Online. Available http://eng.mon.gov.ru/pro/ved/uch/

Ministry of Education and Science, Russian Federation (2010b) "Mr. Putin and Mr. Fursenko discussed the guidelines for a new programme to advance education". Online. Available http://eng.mon.gov.ru/press/news/4295/

Ministry of Education and Science, Russian Federation (2010с) "НАЦИОНАЛЬНЫЕ ИССЛЕДОВАТЕЛЬСКИЕ УНИВЕРСИТЕТЫ”. Online. Available http://mon.gov.ru/ pro/niu/ 
Ministry of Education and Science, Russian Federation (2010d),”ПРИОРИТЕТНЫЙ НАЦИОНАЛЬНЫЙ ПРОЕКТ 'ОБРАЗОВАНИЕ'”. Online. Available http://mon.gov.ru/ pro/pnpo/

Ministry of Education and Science, Russian Federation, "Education in Russia for foreigners". Online. Available http://en.russia.edu.ru/edu/968/

Ministry of Education and Science, Russian Federation, "Priority National Project 'Education"'. Online. Available http://eng.mon.gov.ru/pro/pnpo/

Ministry of Education and Science, Russian Federation, ФЕДЕРАЛЬНОЕ АГЕНТСТВО ПО НАУКЕ И ИННОВАЦИЯМ “Семинар-выставка "Стратегия развития крупных исследовательских инфраструктур Российской Федерации и кооперация с Европейским Союзом" на базе Российского центра науки и культуры в Копенгагене". Online. Available http://www.fasi.gov.ru/news/press-c/1894/

Ministry of Education, Science and Culture, Iceland (2004) "Reykjavik Declaration". Online. Available eng.menntamalaraduneyti.is/.../Arctic_council_member_ states06_2004.doc

Ministry of Education, Science and Culture, Iceland "Styrkir til háskólanáms í Rússlandi”. Online. Available http://www.menntamalaraduneyti.is/frettir/Auglysingar/allar/ $\mathrm{nr} / 4914$

Ministry of Employment and the Economy, Finland (2008) “Ministeri Pekkarinen Pietarissa:'Tulimme paikan päälle innovaatioympäristöä kuulostelemaan”'. Online. Available http://www.tem.fi/index.phtml?96107_m=91143\&s=3407

Ministry of Foreign Affairs, Denmark (2009a)“Economic Development Support Programme for Kaliningrad and Pskov". Online. Available http://www.um.dk/en/ menu/DevelopmentPolicy/DanishDevelopmentPolicyCountries/TheNeighbourhoodPr ogramme/Programmes/EconomicDevelopmentRussia/

Ministry of Foreign Affairs, Denmark (2009b) "Russia”. Online. Available http://www. um.dk/en/menu/DevelopmentPolicy/DanishDevelopmentPolicyCountries/TheNeighb ourhoodProgramme/Countries/Russia/

Ministry of Foreign Affairs, Denmark (2009c) “The Neighbourhood Programme”. Online. Available http://www.um.dk/en/menu/DevelopmentPolicy/Danish DevelopmentPolicyCountries/TheNeighbourhoodProgramme/

Ministry of Foreign Affairs, Norway (2006) The Norwegian Government's High North Strategy. Online. Available www.regjeringen.no/upload/UD/Vedlegg/strategien.pdf, Regrejeringes nordområdestrategi. Online. Available http://www.regjeringen.no/ upload/kilde/ud/pla/2006/0006/ddd/pdfv/302927-nstrategi06.pdf 2006

Ministry of Foreign Affairs, Norway (2007)"Samarbeid med Russland i nordområda". Online. Available http://www.regjeringen.no/nb/dep/ud/kampanjer/ nordomradeportalen/internasjonalt-samarbeid/samarbeid-med-russland-inordomrada.html?id=450749

Ministry of Foreign Affairs, Norway "Nordområdeportalen”. Online. Available http:// www.regjeringen.no/nb/dep/ud/kampanjer/nordomradeportalen.html?id=450629

Ministry of Foreign Affairs, Russian Federation (2008) "The Foreign Policy Concept of the Russian Federation". Online. Available http://www.mid.ru/nsosndoc.nsf/ 0e9272befa34209743256c630042d1aa/cef95560654d4ca5c32574960036cddb?Open Document

Moskovan suomalainen koulu. Online. Available http://www.peda.net/veraja/mossko

Mustajoki Arto (2007) Yliopistojen Venäjä-yhteistyön ja Venäjä -osaamisen kehittäminen, Opetusministeriö: Helsinki. Online. Available http://www.minedu.fi/export/sites/ default/OPM/Julkaisut/2007/liitteet/tr11.pdf?lang=fi

National Board of Education, Finland "Opetushallituksen jakama valtionavustus koulujen kansainvälistymiseen lukuvuodelle 2007-2008”. Online. Available www.edu. ouka.fi/portaalifiles1/File/Mattila_kvrahoista_0708.pdf

Nordic Council of Ministers (2008) The Nordic Region in an International Perspective. Nordic co-operation in a European Framework 2007. 
Nordic Council of Ministers (2010) The Knowledge Building and Networking Programme for co-operation with North-West Russia. Online. Available http://www.norden.org/ en/publications/publications/2010-727

Nordic Council of Ministers, "Nordic Co-operation in the Arctic". Online. Available http://www.norden.org/en/about-nordic-co-operation/areas-of-co-operation/thearctic/nordic-co-operation-in-the-arctic

Nordic Council of Ministers, "Nordic co-operation with Russia". Online. Available http://www.norden.org/en/about-nordic-co-operation/areas-of-co-operation/russia

Norric (2005) The system of education in Russia. Online. Available http://norric.org/ files/education-systems/Ruslandsrapport-feb2005.pdf

Northern Dimension Institute, "NDI - Northern Dimension Institute”. Online. Available http://www.ndinstitute.org/

Norwegian Centre for International Cooperation in Higher Education (SIU) \& Nordic Council of Ministers, "Cooperation with Northwest Russia in Education - Guidelines for applicants 2009".

Norwegian Centre for International Cooperation in Higher Education (SIU) (2009) Mobilitetsrapport 2009. Online. Available http://www.siu.no/eng/content/download/ 1033/11090/file/SIU_mobilrapport09_skjerm.pdf

Norwegian Centre for International Cooperation in Higher Education (SIU), "Cooperation programme with Russia 2007-2010". Online. Available http://www.siu.no/eng/FrontPage/Programme-information/Neighbouring-countries/Cooperation-programmewith-Russia-2007-2010

Norwegian Centre for International Cooperation in Higher Education (SIU) "Kvoteordningen". Online. Available http://www.siu.no/nor/Hoeyere-utdanning-ogforskning/Samarbeid-med utviklingsland/Kvoteordningen

Norwegian Centre for International Cooperation in Higher Education (SIU) "Nordområdestipend". Online. Available http://www.siu.no/nor/Hoeyere-utdanning-ogforskning/Samarbeid-med-naboland/Nordomraadestipend

Norwegian Centre for International Cooperation in Higher Education (SIU), "Scheme for Norwegian studies at higher education institutions abroad". Online. Available http://www.siu.no/eng/Front-Page/Policies-and-relations/Norway-in-a-globalcontext/Scheme-for-Norwegian-studies-at-higher-education-institutionsabroad/\%28view\%29/6479

OECD (2004) Survey of Higher Education Systems. Online. Available http://www. oecd.org/dataoecd/41/59/32503573.PDF

Pelikhov Nikolay and Zverev Nikolay (2004) “Interuniversity co-operative institutions for academic mobility", in Shattock Michael (ed.) Entrepreneurialsm and the transformation of Russian universities.

Pietarin suomalainen koulu. Online. Available http://www.peda.net/veraja/piesko

Research Council of Norway (2010a) "Enhancing Norwegian-Russian cooperation: Strengthening social science research on Russia". Online. Available http://www. forskningsradet.no/servlet/Satellite?c=Nyhet\&cid=1253955143508\&lang= en\&pagename $=$ nord $\% 2 \mathrm{FHovedsidemal}$

Research Council of Norway (2010b) “Good neighbourly relations and mutual interests: Russia - an increasingly important research partner for Norway". Online. Available http://www.forskningsradet.no/en/Newsarticle/Russia_an_increasingly_important_r esearch_partner_for_Norway/1253963176883

Research Council of Norway (2010c) "Norwegian-Russian workshop". Online. Available http://www.forskningsradet.no/servlet/Satellite?c=Page\&cid=1253954327624\&page name=petromaks $\% 2$ FHovedsidemal

Research Council of Norway (2010d) "Russia”. Online. Available http://www. forskningsradet.no/en/Russia/1253956512669

Research Council of Norway (2010e) "The PETROMAKS programme contributes additional funding for researchers from Brazil and Russia”. Online. Available 
http://www.forskningsradet.no/servlet/Satellite?c=Nyhet\&cid=1253962939049\&p=1 226993690988\&pagename=petromaks\%2FHovedsidemal

Research Council of Norway, "Optimal Management of Petroleum Resources, PETROMAKS”. Online. Available http://www.forskningsradet.no/servlet/

Satellite?c=Page $\&$ cid $=1226993690920 \& \mathrm{p}=1226993690920 \&$

pagename=petromaks\%2FHovedsidemal

Research Council of Norway, "Yggdrasil - young guest and doctoral researchers' annual scholarships for investigation and learning". Online. Available http://www.

forskningsradet.no/en/Funding/ISMOBIL/1253955432506?progId=

1233557743178\&visAktive=true

Research Council of Norway, "Yggdrasil - young guest and doctoral researchers' annual scholarships for investigation and learning". Online. Available http://www.

forskningsradet.no/en/Funding/ISMOBIL/1253955432506

Russkiy Mir Foundation, "About Foundation”. Online. Available http://www. russkiymir.ru/russkiymir/en/fund/about

Russian-Icelandic Institute of Renewable Energy. Online. Available http://www. riire.com/RIIRE/English.html

Sámi University College, "Sámi University College- the sámi guiding star". Online. Available http://www.samiskhs.no/index.php?c=220\&kat=S\%E1mi+University+College\&p=

Skolverket, "Betyg och studieresultat i gymnasieskolan läsår 2009/10”. Online. Available http://www.skolverket.se/sb/d/1721

Stockholm Institute for Transition Economics, "Russia and Eastern Europe". Online. Available http://www.hhs.se/SITE/RussiaEast/Pages/default.aspx

Совет при Президенте России по реализации приоритетных национальных проектов и демографической политеке (2006) “Приоритетные национальные проекты". Online. Available http://www.rost.ru/main/what/01/01.shtml

Stockholm School of Economics in Russia. Online. Available http://www.sseru.org/

Study in Sweden, “Visby Program - Swedish Institute's Baltic Sea Region Exchange Program for master's level studies in Sweden". Online. Available http://www. studyinsweden.se/Scholarships/SI-scholarships/Visby-Program/Masters-levelstudies/

Study in Sweden, "Visby Program for students of Swedish language and literature". Online. Available http://www.studyinsweden.se/Scholarships/SI-scholarships/VisbyProgram/Swedish-language-and-literature/

Swedish Council for Working Life and Social Reserch. Online. Available www.fas.se/upload/dokument/Remissvar/.../Internationell\%20strategi.pdf

Swedish Institute (2010a) “Akademiska långtidsstipendier". Online. Available http://www.si.se/Svenska/Innehall/Stipendier-och-utbyte/Visbyprogrammet/ Att-ansoka/Langtidsstipendier/

Swedish Institute (2010b) "Akademiska projektsamarbeten". Online. Available http://www.si.se/Svenska/Innehall/Stipendier-och-utbyte/Visbyprogrammet/Attansoka/Projektsamarbeten/

Swedish Institute (2010c) “Events”. Online. Available http://www.si.se/English/ Navigation/Scholarships-and-exchanges/The-Visby-Program/Events/

Swedish Institute (2010d) “Gymnasiesamarbeten”. Online. Available http://www.si.se/Svenska/Innehall/Stipendier-och-utbyte/Visbyprogrammet/Attansoka/Gymnasiesamarbeten/

Swedish Institute (2010e)"Kontaktbesök och konferenser på akademisk nivå". Online. Available http://www.si.se/Svenska/Innehall/Stipendier-och-utbyte/ Visbyprogrammet/Att-ansoka/Kontaktbesok-och-konferenser/

Swedish Institute (2010f) "Visbyprogrammet - Svenska institutets Östersjöprogram”. Online. Available http://www.si.se/Svenska/Innehall/Stipendier-och-utbyte/ Visbyprogrammet/ 
Swedish Institute (2010g) "130 foreign students accepted to the Visby Program Summer University". Online. Available http://www.si.se/English/Navigation/Scholarships-andexchanges/The-Visby-Program/The-Visby-Program-Summer-University-2010/

Swedish International Development Cooperation Agency (2010a) "Moscow School stimulerar unga att forma ett modernare Ryssland". Online. Available http://www.sida.se/Svenska/Lander--regioner/Europa/Ryssland/Program-ochprojekt/Moscow-School-stimulerar-unga-forma-modernare-Ryssland/

Swedish International Development Cooperation Agency (2010b) "Vårt arbete i Ryssland". Online. Available http://www.sida.se/Svenska/Lander--regioner/ Europa/Ryssland/Vart-arbete-i-Ryssland/

Swedish International Development Cooperation Agency (2010c) “Östersjöenheten kastar loss från Sida". Online. Available http://www.sida.se/Svenska/Samarbetsparter/ Ostersjosamarbete/Om-samarbetet/Ostersjoenheten-kastar-loss-fran-Sida-/

Swedish National Agency for Higher Education (2010) "Internationell mobilitet i högskolan 2008/2009". Online. Available http://www.hsv.se/download/ 18.7b9d013127a9e59c048000505/UF20SM1001.pdf

Swedish Polar Research Secretariat (2010) “Tajmyr”. Online. Available http://www. polar.se/expeditioner/swedarctic2010/tajmyr.html

Swedish Research Council (2010) "Politically important geographic regions”. Online. Available http://www.vr.se/inenglish/researchsupported/researchenvironments/ strategicresearchareas/politicallyimportantgeographicregions. 4.6e3f84f912af3e345e780002265.html

Svenska Skolan i Moskva. Online. Available http://www.ssim.nu/

Sverker Åströms Stiftelse för främjande av de svensk-ryska förbindelserna. Online. Available http://www.sverkerastromfoundation.se/svenska/stiftelsen.htm

Tahvanainen Liisa and Fors Eero (2009) "Quality Assurance System in the FinnishRussian Cross-Border University (CBU)" in University of Turku, Quality Handbook of Higher Education in Finland and Russia, Turku: University of Turku. Online. Available www.utu.fi/en/university/quality/russia/handbook.pdf

The Árni Magnùsson Institute for Icelandic Studies, "Icelandic government scholarships". Online. Available http://www.arnastofnun.is/page/a_inter_scholarships

The Árni Magnùsson Institute for Icelandic Studies,"Icelandic lecturers abroad". Online. Available http://www.arnastofnun.is/page/all_lecturers

The Kolarctic ENPI CBC. Programme 2007-2013. Online. Available http://www. kolarcticenpi.info/c/document_library/get_file?folderId=210352\&name=DLFE5982.pdf

The Norwegian Barents Secretariat, "Guidelines and Conditions". Online. Available http://www.barents.no/guidelines-and-conditions.151500.en.html

Toivonen N.R. (2004) "Regional international co-operation and development as a way of funding a university: the case of Petrozavodsk State University" in Shattock Michael (ed.) Entrepreneurialsm and the transformation of Russian universities.

Undervisningsministeriet (2004) Råd og vink om internationalisering hhx. Online. Available http://pub.uvm.dk/2004/hhxint/

Undervisningsministeriet \& Ministeriet for Videnskab, Teknologi og Udvikling (2004) Styrket internationalisering af uddannelserne -Redegørelse til Folketinget. Online. Available http://pub.uvm.dk/2004/internationalisering/

Undervisningsministeriet (2009) Flere studerende på studie- og praktikophold i udlandet. Online. Available http://www.uvm.dk/service/Publikationer/Publikationer/ Videregaaende\%20uddannelser/2009/Flere\%20studerende\%20paa\%20studie\%20og\%20praktikophold\%20i\%20udlandet.aspx?r=1

Unesco, “Baltic Sea project”. Online. Available http://www.unesco.org/new/en/ education/networks/global-networks/aspnet/flagship-projects/baltic-sea-project/

Unesco, "The UNESCO Associated Schools Project Network". Online. Available http://www.unesco.org/new/en/education/networks/global-networks/aspnet/ 
University of Arctic, "Where can I go". Online. Available http://www.uarctic.org/ SingleArticle.aspx?m=107\&amid=238

University of Arctic, “BCS Core Courses”. Online. Available http://www.uarctic.org/ SingleArticle.aspx? $\mathrm{m}=468 \&$ amid $=3009$

University of Arctic, “Where to go". Online. Available http://www.uarctic.org/ singleArticle.aspx?m=107\&amid $=238$

University of Artic. Online. Available http://www.uarctic.org/Frontpage.aspx?m=3

University of Eastern Finland (2010) "Venäjä-osaamiseen ja opettajankoulutukseen strategiarahaa 5 miljoonaa euroa". Online. Available http://www.uef.fi/uef /tiedotteet2?p_p_id=101_INSTANCE_1cUp\&p_p_lifecycle=0\&p_p_state=normal\&p_p_m ode=view\&p_p_col_id=column-2\&p_p_col_pos $=1 \&$ p_p_col_count $=14 \& \_101$

INSTANCE_1cUp_struts_action=\%2Fasset_publisher\%2Fview_content\&_101_ INSTANCE_1cUp_urlTitle=20101210-venaja-osaamiseen-1\&_101_INSTANCE_1cUp_ type $=$ content $\&$ redirect $=\% 2$ Fuef $\% 2$ Ftiedotearkisto -2010

University of Nordland (2009)“Bodø University College and Russian Northern Area University in Arkhangel offer combined teaching". Online. Available http://www. hibo.no/index.php?ID=12848\&lang=eng\&displayitem=2874\&module=news

University of Turku (2009) Quality Handbook of Higher Education in Finland and Russia, Turku: University of Turku. Online. Available www.utu.fi/en/university/quality/ russia/handbook.pdf

Uppsala University, “UCRS Uppsala Centre for Russian and Eurasian Studies”. Online. Available http://www.ucrs.uu.se/About+the+Centre+/

Zornikov Igor (2004)“Internationalization and academic mobility in Russian universities" in Shattock Michael (ed.) Entrepreneurialsm and the transformation of Russian universities.

Östersjöstiftelsen. Online. Available http://www.ostersjostiftelsen.se/default.aspx 


\section{Sammanfattning}

Denna undersökning, gjord på uppdrag av Nordiska ministerrådet, kartlägger existerande och planerat utbildnings- och forskningssamarbete mellan de nordiska länderna (Danmark, Finland, Island, Norge och Sverige) och Ryssland på bilateral, nordisk, regionalt mellanstatlig och EUnivå. Den omfattar alla forskningsområden och alla utbildningsnivåer: grundskolan, gymnasiet, yrkesskolorna, högskolorna och vuxenutbildningen. Undersökningen fokuserar på program på mellanstatlig nivå men ger också en kort översikt av det samarbete som genomförs av nordiska utbildnings- och forskningsinstitutioner. Den faller inom två centrala temakomplex: forskningens och utbildningens internationalisering, som är en global process, och den post-sovjetiska scenen. Efter Sovjetunionens sönderfall började Ryssland visa intresse för internationellt samarbete inom forskning och utbildning, medan de nordiska länderna började fördjupa sitt samarbete med Ryssland på många områden, inklusive utbildning och forskning. Kapitel 1.2 ger en kort överblick över den nyare utvecklingen inom denna sektor i Ryssland.

Undersökningens fokus ligger på det bilaterala planet och kapitel 2 kartlägger det utbildnings- och forskningssamarbete de nordiska länderna har med Ryssland. Utbildningens och forskningens internationaliseringsprocess röner kraftigt understöd i Danmark, men de rådande strategierna betonar inte samarbete med Ryssland på geografisk grund. Danmark och Ryssland har ett avtal om kultur, utbildning och forskning och en stipendieplan står till förfogande för student- och forskarutbyte inom ramen för detta. Ytterligare understöder och främjar Danmark undervisningen i danska vid två ryska institutioner för högre utbildning och har genomfört ett biståndsprogram för ekonomisk utveckling i regionerna Pskov och Kaliningrad som omfattar en omorganisation av deras yrkesutbildningsinstitutioner. Finland och Ryssland har två avtal om utbildning och vetenskap och många strategier på det statliga planet betonar samarbetet länderna emellan inom utbildning och forskning. Ett flertal finansieringsplaner är disponibla för många olika områden och för alla utbildnings- och forskningsinstanser som koordinerar sådant samarbete. CIMO, Centret för internationell mobilitet och internationellt samarbete, samordnar flera stipendier och samarbetsprogram inom den högre utbildningen. Finlands Akademi idkar samarbete i stor skala med ryska forskningsinstitut och finansieringsinstanser. Utbildningsstyrelsen samordnar programmen för gymnasienivån och yrkeskolorna. Programmet för närområdessamarbete finansierar ett flertal utbildningsprojekt tillsammans med Ryssland. Dessutom inriktar sig flera institut- 
ioner/universitet på Ryssland. Island prioriterar däremot inte bilateralt samarbete med Ryssland inom utbildning och forskning och dess omfattning är därför rätt ringa. Islands avtal med Ryssland om kultur, vetenskap och utbildning är inte särskilt handlingsbetonat och det finns inga planer på att utvidga det inom en nära framtid. Norge har valt strategier som lägger tonvikten på samverkan i nordområdena. Detta gäller också samarbetet med Ryssland inom utbildning och forskning, där för närvarande två mellanstatliga avtal existerar. Många stipendier och samarbetsprogram för olika områden och nivåer koordineras av det norska centret för internationalisering av högre utbildning (SIU), Norges forskningsråd och Norska Barentssekretariatet. Norges forskningsråd har dessutom ett flertal forskningsprogram med fokus på Ryssland. Vidare har aktörer på det institutionella planet investerat egna resurser i samarbete med Ryssland. Sverige och Ryssland har för närvarande inga avtal inom utbildning och forskning. Den viktigaste resursen för samarbete med Ryssland inom dessa områden är Svenska institutets (SI) Visbyprogram som prioriterar samverkan med Ryssland, men som sannolikt kommer att förändras efter en eventuell fusion av Sida Östersjöenheten med Svenska institutet. Andra former för samarbete inom utbildning står till förfogande och i fråga om forskning har Ryssland definierats som en strategiskt viktig region. Helt allmänt upprätthåller många nordiska institutioner inom högre utbildning och forskning liksom också ett antal skolor samarbetsavtal med sina ryska motsvarigheter. Sådant samarbete finansieras genom de ovan nämnda statliga programmen eller andra källor, inklusive de nedannämnda.

Kapitel 3 redogör för samarbetet inom utbildning och forskning mellan mellanstatliga organisationer såsom Nordiska ministerrådet, Östersjöstaternas råd, Barents euroarktiska råd och Arktiska rådet. Alla dessa deltar i någon mån i utbildnings- och forskningsrelaterat samarbete, men Östersjöstaternas råd och Nordiska ministerrådet har större resurser att förverkliga rysk-nordiskt utbildningssamarbete. Kapitel 4 behandlar i korthet samarbetet mellan EU och Ryssland eftersom detta också ur nordiskt perspektiv är ett viktigt forum genom att alla de nordiska länderna är engagerade, antingen i sin egenskap av medlemsstat eller genom EES-avtalet.

Undersökningen visar att alla nordiska länder deltar i någon form av samarbete med Ryssland inom utbildning och forskning. Respektive anslagna resurser och gjorda prioriteringar varierar däremot ansenligt. Samarbetet är intensivast i den till Ryssland gränsande geografiska regionen (Nordnorge och Finland). Nordvästra Ryssland har traditionellt varit samarbetsområde men under senare år har den geografiska omfattningen utvidgats. Regionala mellanstatliga organisationer och EU utökar samarbetsresurserna på det nationella och bilaterala planet och skapar en ram för multilateral samverkan med Ryssland. Denna är intensivast inom den högre utbildningen och forskningen. Inom vuxenut- 
bildningen förekommer däremot egentligt samarbete i mycket liten utsträckning. Inom grundutbildningen och på gymnasie- och yrkesutbildningsnivån existerar samarbete i någon mån. Rysslands ekonomiska tillväxt och utveckling har medfört en övergång från biståndsprogram till betoning av samarbete med ömsesidiga prioriteringar och gemensam finansiering. Ryssland har redan deltagit i kostnaderna för gemensamma forskningsprojekt och har också ordnat finansiering av vissa program med EU, såsom det Europeiska grannskaps- och partnerskapsinstrumentets gränsöverskridande samarbetsprogram (ENPI CBC). Frågorna om programprioriteringar och gemensam finansiering är synnerligen relevanta också i samarbetet mellan Norden och Ryssland. 



\section{Appendix}

\subsection{A list of organisations that have provided additional information for the study}

The number of additional queries to relevant authorities has varied by country. In the case of Finland, for example, additional queries to many different organisations were unnecessary.

\section{Denmark}

Association for Russian language teachers in Denmark

City of Aarhus

City of Alborg

Copenhagen Business School

Danish Agency for International Education, Ministry of Science, Technology and Innovation

Danish Agency for Science, Technology and Innovation, Ministry of Science, Technology and Innovation

Danish University and Property Agency, Ministry of Science, Technology and Innovation

Local government in Denmark

Ministry of Education

Ministry for Foreign Affairs of Denmark

Regional Municipality of Bornholm

University of Copenhagen

University of Aarhus

\section{Finland}

Academy of Finland

CIMO - Centre for International Mobility

Finnish National Board of Education

Ministry of Education and Culture

University of Turku

\section{Iceland}

Bifröst University

Icelandic Centre for Research - RANNIS

Office of International Education, University of Iceland

Ministry of Education, Science and Culture

School for Renewable Energy Science

University of Iceland 


\section{Norway}

Finnmark University College

Fylkesmannen i Finnmark (County of Finnmark)

Ministry of Education and Research

Norwegian Barents Secretariat

Norwegian Centre for International Cooperation in Higher Education

Norwegian Centre for Foreign Languages in Education

Norwegian University Centre in Saint Petersburg

Research Council of Norway

\section{Sweden}

Embassy of Sweden in Moscow

International Programme Office for Education and Training

Lund University

Ministry of Education and Research

Ministry for Foreign Affairs of Sweden

Skolverket

Svenska Skolan i Moskva

Swedish Association of Local Authorities and Regions

Swedish Institute

Swedish National Agency for Higher Education

Swedish Research Council (Vetenskapsrådet)

Swedish Research Council Formas

\section{Arctic Council}

Bonus Secretariat (EEIG)

Council of the Baltic Sea States

Kolarctic ENPI CBC programme office

NordForsk

Nordic Council of Ministers

Northern Dimension Institute

University of the Arctic 


\subsection{Nordic countries' bilateral education and research cooperation with Russia.}

The table presents the forms of cooperation in a simplified form; for detailed information, see section 2.

\begin{tabular}{|c|c|c|c|c|c|}
\hline $\begin{array}{l}\text { Forms of } \\
\text { cooperation }\end{array}$ & Denmark & Finland & Iceland & Norway & Sweden \\
\hline $\begin{array}{l}\text { State } \\
\text { agreements } \\
\text { with } \\
\text { Russian } \\
\text { Federation } \\
\text { in the fields } \\
\text { of educa- } \\
\text { tion and } \\
\text { research }\end{array}$ & $\begin{array}{l}\text { Agreement on } \\
\text { Cooperation } \\
\text { in the fields of } \\
\text { Culture, } \\
\text { Science and } \\
\text { Education } \\
\text { (1993). }\end{array}$ & $\begin{array}{l}\text { Agreement on } \\
\text { Cooperation in the } \\
\text { fields of Culture, } \\
\text { Education and } \\
\text { Science and Agree- } \\
\text { ment on Coopera- } \\
\text { tion in Science and } \\
\text { Technology (1992). }\end{array}$ & $\begin{array}{l}\text { Agreement on } \\
\text { Cooperation in } \\
\text { the fields of } \\
\text { Culture, Science } \\
\text { and Technology } \\
\text { between the } \\
\text { Republic of } \\
\text { Iceland and the } \\
\text { Soviet Union } \\
\text { (1961). }\end{array}$ & $\begin{array}{l}\text { Agreement in the fields } \\
\text { of culture, education } \\
\text { and research (1994), } \\
\text { cooperation agreement } \\
\text { in the fields of education } \\
\text { ( } 2010) \text {, agreement on } \\
\text { scientific \& technologi- } \\
\text { cal cooperation current- } \\
\text { ly under preparation. }\end{array}$ & $\begin{array}{l}\text { At the moment, no } \\
\text { agreement on } \\
\text { cooperation in the } \\
\text { fields of education } \\
\text { and science. The } \\
\text { current cultural } \\
\text { agreement does } \\
\text { not include coop- } \\
\text { eration in educa- } \\
\text { tion and research. }\end{array}$ \\
\hline Schools & $\begin{array}{l}\text { Restructuring } \\
\text { vocational } \\
\text { education in } \\
\text { the Pskov and } \\
\text { Kaliningrad } \\
\text { regions. } \\
\text { Aarhus and } \\
\text { Ålborg school } \\
\text { cooperation. }\end{array}$ & $\begin{array}{l}\text { Neighbouring area } \\
\text { programme. } \\
\text { Finland-Russia } \\
\text { programme. Some } \\
\text { opportunities to } \\
\text { apply for project } \\
\text { funding. }\end{array}$ & - & $\begin{array}{l}\text { Norwegian Barents } \\
\text { Secretariat project } \\
\text { grants. Fylkesmannen i } \\
\text { Finnmark programmes. }\end{array}$ & Visby Programme. \\
\hline $\begin{array}{l}\text { Adult } \\
\text { education }\end{array}$ & - & $\begin{array}{l}\text { Neighbouring area } \\
\text { programme. Some } \\
\text { opportunities to } \\
\text { apply for project } \\
\text { funding. }\end{array}$ & - & $\begin{array}{l}\text { Norwegian Barents } \\
\text { Secretariat project } \\
\text { grants. }\end{array}$ & $\begin{array}{l}\text { Visby Programme } \\
\text { for adult education } \\
\text { has begun to wane. }\end{array}$ \\
\hline $\begin{array}{l}\text { Higher } \\
\text { education }\end{array}$ & $\begin{array}{l}\text { Danish } \\
\text { Government } \\
\text { Scholarships } \\
\text { for Russian } \\
\text { students and } \\
\text { researchers. } \\
\text { Danish } \\
\text { summer } \\
\text { courses for } \\
\text { Russian } \\
\text { students. The } \\
\text { teaching of } \\
\text { Danish in two } \\
\text { Russian HEls. } \\
\text { Bilateral } \\
\text { agreements } \\
\text { with universi- } \\
\text { ties. Russian } \\
\text { language } \\
\text { training } \\
\text { programmes } \\
\text { in Russia. }\end{array}$ & $\begin{array}{l}\text { Neighbouring area } \\
\text { programme. Joint } \\
\text { conference on } \\
\text { Higher Education. } \\
\text { FIRST programme. } \\
\text { Finnish summer } \\
\text { course for Russian } \\
\text { students. Pro- } \\
\text { gramme supporting } \\
\text { the teaching of } \\
\text { Finnish in Russia. } \\
\text { North2North. } \\
\text { Russian language } \\
\text { training pro- } \\
\text { grammes in Russia. } \\
\text { Programmes to } \\
\text { specialise in Russian } \\
\text { studies. HEls have } \\
\text { many bilateral } \\
\text { agreements with } \\
\text { Russia. }\end{array}$ & $\begin{array}{l}\text { Some bilateral } \\
\text { agreements. } \\
\text { north2north. } \\
\text { Icelandic Gov- } \\
\text { ernment Schol- } \\
\text { arships. Russian } \\
\text { language training } \\
\text { programmes in } \\
\text { Russia. }\end{array}$ & $\begin{array}{l}\text { Fellowship programme } \\
\text { for Studies in the High } \\
\text { North. Quota scheme. } \\
\text { Norgeskunnskap pro- } \\
\text { gramme that supports } \\
\text { Norwegian studies in } \\
\text { foreign universities, } \\
\text { including Russia. Coop- } \\
\text { eration Programme with } \\
\text { Russia 2007-2010 and a } \\
\text { new programme from } \\
\text { 2011. BarentsPlus } \\
\text { programme. } \\
\text { North2North. Several } \\
\text { bilateral agreements. } \\
\text { Joint programmes with } \\
\text { Russia. Norwegian } \\
\text { University Centre in } \\
\text { Saint Petersburg. }\end{array}$ & $\begin{array}{l}\text { Visby programme. } \\
\text { Programme sup- } \\
\text { porting the teach- } \\
\text { ing of Swedish in } \\
\text { Russia. Support for } \\
\text { the Moscow School } \\
\text { of Political Studies. } \\
\text { Several HEls have } \\
\text { bilateral coopera- } \\
\text { tion. North2North. } \\
\text { Baltic University } \\
\text { Programme and } \\
\text { other educational } \\
\text { programmes with } \\
\text { Russia. }\end{array}$ \\
\hline
\end{tabular}




\begin{tabular}{|c|c|c|c|c|c|}
\hline $\begin{array}{l}\text { Forms of } \\
\text { cooperation }\end{array}$ & Denmark & Finland & Iceland & Norway & Sweden \\
\hline $\begin{array}{l}\text { Research } \\
\text { Cooperation }\end{array}$ & $\begin{array}{l}\text { Danish } \\
\text { Government } \\
\text { Scholarships } \\
\text { for Russian } \\
\text { students and } \\
\text { researchers. } \\
\text { Research } \\
\text { cooperation } \\
\text { based on } \\
\text { individual } \\
\text { contacts. }\end{array}$ & $\begin{array}{l}\text { CIMO fellowships. } \\
\text { Winter school. } \\
\text { Kindred Nations' } \\
\text { Scholarships for } \\
\text { Finno-Ugrian } \\
\text { minorities in Russia. } \\
\text { Academy of Fin- } \\
\text { land's broad re- } \\
\text { search cooperation } \\
\text { with Russian } \\
\text { research-funding } \\
\text { agencies, including } \\
\text { the mobility of } \\
\text { researchers and } \\
\text { joint calls. Several } \\
\text { research insti- } \\
\text { tutes/departments } \\
\text { with a focus on } \\
\text { Russia/cooperation } \\
\text { with Russia. }\end{array}$ & $\begin{array}{l}\text { Some research } \\
\text { cooperation } \\
\text { based on indi- } \\
\text { vidual contacts. } \\
\text { Arctic research } \\
\text { cooperation. }\end{array}$ & $\begin{array}{l}\text { Yggdrasil grants for } \\
\text { research stays in Nor- } \\
\text { way. Cooperation } \\
\text { Programme with Russia } \\
\text { 2007-2010. Norwegian } \\
\text { University Centre in } \\
\text { Saint Petersburg. } \\
\text { Research cooperation in } \\
\text { several fields. Research } \\
\text { council has NORRUSS } \\
\text { and PETROMAKS and } \\
\text { other research pro- } \\
\text { grammes. Research } \\
\text { council has bilateral } \\
\text { cooperation with } \\
\text { Russian funding and } \\
\text { research organisations. }\end{array}$ & $\begin{array}{l}\text { Visby Programme. } \\
\text { Russia as a political- } \\
\text { ly important } \\
\text { geographical } \\
\text { region. Östersjöstif- } \\
\text { telsen. Research } \\
\text { institutes with a } \\
\text { focus on Russia. }\end{array}$ \\
\hline
\end{tabular}

\subsection{Selection of the Nordic countries' programmes for cooperation with Russia in education and research}

The table does not cover all the programmes presented in the text. For detailed information on all the activities, see their respective

\begin{tabular}{|c|c|c|c|c|c|}
\hline Programme & $\begin{array}{l}\text { Main funding } \\
\text { organisation }\end{array}$ & Coordinator & $\begin{array}{l}\text { Programme } \\
\text { board/steering group }\end{array}$ & $\begin{array}{l}\text { Forms of activities in } \\
\text { education/research }\end{array}$ & Volume \\
\hline $\begin{array}{l}\text { Danish Govern- } \\
\text { ment Scholar- } \\
\text { ships, including } \\
\text { scholarships for } \\
\text { Russians. }\end{array}$ & $\begin{array}{l}\text { Danish } \\
\text { Government. }\end{array}$ & $\begin{array}{l}\text { Danish } \\
\text { Agency for } \\
\text { International } \\
\text { Education. }\end{array}$ & $\begin{array}{l}\text { No board/steering } \\
\text { group for the pro- } \\
\text { gramme with Russia. }\end{array}$ & $\begin{array}{l}60 \text { months of scholar- } \\
\text { ships (DKK 5000) are } \\
\text { awarded annually to } \\
\text { young Russian gradu- } \\
\text { ates or researchers } \\
\text { for studies in Den- } \\
\text { mark, and } 6 \text { scholar- } \\
\text { ships are awarded for } \\
\text { a Danish language } \\
\text { summer course. }\end{array}$ & $\begin{array}{l}\text { See the adjacent } \\
\text { box. }\end{array}$ \\
\hline $\begin{array}{l}\text { Lecturer Scheme, } \\
\text { also valid for } \\
\text { Russia. }\end{array}$ & $\begin{array}{l}\text { Ministry of } \\
\text { Science, } \\
\text { Technology } \\
\text { and Innova- } \\
\text { tion, Den- } \\
\text { mark. }\end{array}$ & $\begin{array}{l}\text { Danish } \\
\text { University } \\
\text { and Property } \\
\text { Agency. }\end{array}$ & $\begin{array}{l}\text { Lectureship commit- } \\
\text { tee. }\end{array}$ & $\begin{array}{l}\text { To disseminate } \\
\text { awareness of Danish } \\
\text { language, literature } \\
\text { and culture abroad. } \\
\text { Moscow State Univer- } \\
\text { sity and Saint Peters- } \\
\text { burg State University } \\
\text { have employed a } \\
\text { Danish lecturer, to } \\
\text { whom the Danish } \\
\text { University and Prop- } \\
\text { erty Agency, provides } \\
\text { a personal subsidy. }\end{array}$ & $n / a$ \\
\hline
\end{tabular}




\begin{tabular}{|c|c|c|c|c|c|}
\hline Programme & $\begin{array}{l}\text { Main funding } \\
\text { organisation }\end{array}$ & Coordinator & $\begin{array}{l}\text { Programme } \\
\text { board/steering group }\end{array}$ & $\begin{array}{l}\text { Forms of activities in } \\
\text { education/research }\end{array}$ & Volume \\
\hline $\begin{array}{l}\text { Economic Devel- } \\
\text { opment Support } \\
\text { Programme in } \\
\text { Kaliningrad and } \\
\text { Pskov Oblasts, } \\
\text { Russia 2005-- } \\
\text { 2010, including a } \\
\text { sub-component } \\
\text { for vocational } \\
\text { education. }\end{array}$ & $\begin{array}{l}\text { The Roayl } \\
\text { Danish } \\
\text { Ministry of } \\
\text { Foreign } \\
\text { Affairs }\end{array}$ & $\begin{array}{l}\text { Coordination } \\
\text { of the com- } \\
\text { ponent for } \\
\text { vocational } \\
\text { education by } \\
\text { Danida } \\
\text { advisors in } \\
\text { Kalinin- } \\
\text { grad/Pskov in } \\
\text { cooperation } \\
\text { with Gront- } \\
\text { mij/CarlBro, } \\
\text { supervised by } \\
\text { the Neigh- } \\
\text { bourhood } \\
\text { Depart- } \\
\text { ment/MFA in } \\
\text { Copenhagen. }\end{array}$ & $\begin{array}{l}\text { No specific pro- } \\
\text { gramme } \\
\text { board/steering group } \\
\text { for the sub- } \\
\text { component of voca- } \\
\text { tional education. }\end{array}$ & $\begin{array}{l}\text { The restructuring of } \\
\text { vocational education } \\
\text { and training (VET) } \\
\text { systems is one of the } \\
\text { sub-components of } \\
\text { the EDSP programme. }\end{array}$ & $\begin{array}{l}\text { According to the } \\
\text { programme docu- } \\
\text { ment, the budget for } \\
\text { the entire pro- } \\
\text { gramme is DKK } 110 \\
\text { million; the budget } \\
\text { for the sub- } \\
\text { component was DKK } \\
32.925 \text { million for } \\
\text { the programme } \\
\text { period } 2005-2010 \text {. }\end{array}$ \\
\hline $\begin{array}{l}\text { Neighbouring } \\
\text { Area Cooperation } \\
\text { Programme with } \\
\text { Russia, including } \\
\text { education activi- } \\
\text { ties. }\end{array}$ & $\begin{array}{l}\text { Government } \\
\text { of Finland }\end{array}$ & $\begin{array}{l}\text { For educa- } \\
\text { tional activi- } \\
\text { ties, the } \\
\text { Ministry of } \\
\text { Education and } \\
\text { Culture and } \\
\text { the National } \\
\text { Board of } \\
\text { Education. }\end{array}$ & $n / a$ & $\begin{array}{l}\text { Funding for educa- } \\
\text { tional cooperation } \\
\text { projects between } \\
\text { Finland and Russia. }\end{array}$ & $\begin{array}{l}\text { The } 2010 \text { budget for } \\
\text { education projects } \\
\text { financed by the } \\
\text { Ministry of Education } \\
\text { and Culture was EUR } \\
771000 \text {. }\end{array}$ \\
\hline $\begin{array}{l}\text { FIRST (Finnish- } \\
\text { Russian Student } \\
\text { and Teacher } \\
\text { Exchange Pro- } \\
\text { gramme) }\end{array}$ & $\begin{array}{l}\text { Ministry of } \\
\text { Education and } \\
\text { Culture, } \\
\text { Finland. }\end{array}$ & $\begin{array}{l}\text { Centre for } \\
\text { International } \\
\text { Mobility } \\
\text { (CIMO) }\end{array}$ & $\begin{array}{l}\text { No specific steering } \\
\text { group for FIRST; } \\
\text { rather an advisory } \\
\text { group for all CIMO's } \\
\text { higher education } \\
\text { programmes. }\end{array}$ & $\begin{array}{l}\text { Scholarships for } \\
\text { student and teacher } \\
\text { mobility from Finland } \\
\text { to Russia and from } \\
\text { Russia to Finland. } \\
\text { Funding provided for } \\
\text { intensive courses. }\end{array}$ & $\begin{array}{l}\text { The } 2011 \text { budget is } \\
\text { about EUR } 600000 \text {. }\end{array}$ \\
\hline $\begin{array}{l}\text { CIMO Fellowships, } \\
\text { the programme } \\
\text { includes special } \\
\text { focus to Russia. }\end{array}$ & $\begin{array}{l}\text { Ministry of } \\
\text { Education and } \\
\text { Culture, } \\
\text { Finland. }\end{array}$ & $\begin{array}{l}\text { Centre for } \\
\text { International } \\
\text { Mobility } \\
\text { (CIMO). }\end{array}$ & $\begin{array}{l}\text { No own steering } \\
\text { group/ board, but } \\
\text { experts from different } \\
\text { study fields evaluate } \\
\text { applications. }\end{array}$ & $\begin{array}{l}\text { Scholarships for } \\
\text { foreign doctoral } \\
\text { students and re- } \\
\text { searchers to come to } \\
\text { do research in Fin- } \\
\text { land. }\end{array}$ & $\begin{array}{l}\text { Budget has been in } \\
\text { recent years about } \\
\text { EUR } 970000 \text {, and } \\
\text { the percentage of } \\
\text { accepted Russian } \\
\text { researchers has been } \\
\text { about } 25 \% \text { of select- } \\
\text { ed applicants. }\end{array}$ \\
\hline $\begin{array}{l}\text { CIMO winter } \\
\text { school for Russian } \\
\text { and Ukrainian } \\
\text { students. }\end{array}$ & $\begin{array}{l}\text { Ministry of } \\
\text { Education and } \\
\text { Culture, } \\
\text { Finland. }\end{array}$ & $\begin{array}{l}\text { Centre for } \\
\text { International } \\
\text { Mobility } \\
\text { (CIMO). }\end{array}$ & $\begin{array}{l}\text { No officially designat- } \\
\text { ed steering group; } \\
\text { rather, an informal } \\
\text { steering group that } \\
\text { includes three Finnish } \\
\text { professors and a } \\
\text { representative from } \\
\text { CIMO. }\end{array}$ & $\begin{array}{l}\text { Annual winter school } \\
\text { in Finland for Russian, } \\
\text { Ukrainian and Finnish } \\
\text { doctoral candidates } \\
\text { studying various } \\
\text { topics. }\end{array}$ & $\begin{array}{l}\text { The annual budget of } \\
\text { the winter school is } \\
\text { about EUR } 40000 .\end{array}$ \\
\hline $\begin{array}{l}\text { Kindred Nations' } \\
\text { Scholarships for } \\
\text { Finno-Ugrian } \\
\text { minorities in } \\
\text { Russia; a Kindred } \\
\text { Nations' course in } \\
\text { Russia. }\end{array}$ & $\begin{array}{l}\text { Ministry of } \\
\text { Education and } \\
\text { Culture, } \\
\text { Finland. }\end{array}$ & $\begin{array}{l}\text { Centre for } \\
\text { International } \\
\text { Mobility } \\
\text { (CIMO). }\end{array}$ & $\begin{array}{l}\text { An advisory board for } \\
\text { the Kindred Nations' } \\
\text { programme, consist- } \\
\text { ing of nine members. }\end{array}$ & $\begin{array}{l}\text { Scholarships for } \\
\text { research stays in } \\
\text { Finland, a Kindred } \\
\text { Nations' course in } \\
\text { Russia. }\end{array}$ & $\begin{array}{l}\text { The annual budget } \\
\text { for scholarships is } \\
\text { EUR } 60000 \text {. The } \\
\text { annual budget for } \\
\text { the course is EUR } 15 \\
000 \text {. }\end{array}$ \\
\hline
\end{tabular}




\begin{tabular}{|c|c|c|c|c|c|}
\hline Programme & $\begin{array}{l}\text { Main funding } \\
\text { organisation }\end{array}$ & Coordinator & $\begin{array}{l}\text { Programme } \\
\text { board/steering group }\end{array}$ & $\begin{array}{l}\text { Forms of activities in } \\
\text { education/research }\end{array}$ & Volume \\
\hline $\begin{array}{l}\text { Programme } \\
\text { related to teach- } \\
\text { ing of Finnish } \\
\text { language abroad, } \\
\text { also including } \\
\text { Russia. }\end{array}$ & $\begin{array}{l}\text { Ministry of } \\
\text { Education and } \\
\text { Culture, } \\
\text { Finland. }\end{array}$ & $\begin{array}{l}\text { Centre for } \\
\text { International } \\
\text { Mobility } \\
\text { (CIMO). }\end{array}$ & $\begin{array}{l}\text { Advisory Group for } \\
\text { Finnish Studies at } \\
\text { Universities abroad, } \\
\text { including chair and } 10 \\
\text { members. }\end{array}$ & $\begin{array}{l}\text { Finnish language and } \\
\text { culture courses in } \\
\text { Finland for students, } \\
\text { scholarships for } \\
\text { researcher of Finnish } \\
\text { language, Activities } \\
\text { related to teaching of } \\
\text { Finnish, lecturers to } \\
\text { Russia. }\end{array}$ & $\begin{array}{l}\text { Total budget of all } \\
\text { activities concerning } \\
\text { Russia not available. } \\
\text { At the moment the } \\
\text { programme provides } \\
\text { six lecturers of Finnish } \\
\text { language to Russia } \\
\text { and other support } \\
\text { related to teaching of } \\
\text { Finnish in Russian } \\
\text { universities. Concern- } \\
\text { ing the scholarships, } \\
\text { there's no quota for } \\
\text { Russian students, but } \\
\text { applications are } \\
\text { evaluated on the } \\
\text { basis of excellence. }\end{array}$ \\
\hline $\begin{array}{l}\text { Finnish Centre for } \\
\text { Russian and } \\
\text { Eastern European } \\
\text { Studies. }\end{array}$ & $\begin{array}{l}\text { Ministry of } \\
\text { Education and } \\
\text { Culture, } \\
\text { Finland, } \\
\text { University of } \\
\text { Helsinki and } \\
\text { external } \\
\text { sources. }\end{array}$ & $\begin{array}{l}\text { Aleksanteri } \\
\text { Institute, } \\
\text { Finnish Centre } \\
\text { for Russian } \\
\text { and Eastern } \\
\text { European } \\
\text { Studies. }\end{array}$ & $\begin{array}{l}\text { Board of trustees } \\
\text { consisting of chair and } \\
\text { nine members, ten } \\
\text { vice-members. }\end{array}$ & $\begin{array}{l}\text { Four educational } \\
\text { programmes from BA } \\
\text { to PhD level. Coordi- } \\
\text { nation of Russian } \\
\text { language training } \\
\text { programme in Russia } \\
\text { for Finnish students } \\
\text { majoring in Russian } \\
\text { studies. National role } \\
\text { to promote Russian } \\
\text { and Eastern European } \\
\text { studies in Finland and } \\
\text { to coordinate the } \\
\text { network, to conduct } \\
\text { research projects. } \\
\text { Visiting Scholars } \\
\text { Programme. Infor- } \\
\text { mation services. } \\
\text { Many international } \\
\text { activities and semi- } \\
\text { nars/conferences } \\
\text { open to wider audi- } \\
\text { ences. }\end{array}$ & $\begin{array}{l}\text { Annual budget is } \\
\text { about EUR } 3 \text { million. } \\
\text { Funding from the } \\
\text { Ministry of Education } \\
\text { and Culture is EUR } 1.5 \\
\text { million annually. }\end{array}$ \\
\hline $\begin{array}{l}\text { Academy of } \\
\text { Finland, Russia } \\
\text { activities. }\end{array}$ & Varies by call. & $\begin{array}{l}\text { Acedemy of } \\
\text { Finland. }\end{array}$ & $\begin{array}{l}\text { Currently no dedicat- } \\
\text { ed steering group for } \\
\text { the Academy's Russia } \\
\text { activities. }\end{array}$ & $\begin{array}{l}\text { Researcher mobility, } \\
\text { joint calls and other } \\
\text { forms of cooperation } \\
\text { with RAS, RFBR and } \\
\text { RFH. }\end{array}$ & $\begin{array}{l}\text { The annual volume } \\
\text { of cooperation varies } \\
\text { by joint call and } \\
\text { programme. }\end{array}$ \\
\hline $\begin{array}{l}\text { Finland-Russia } \\
\text { programme for } \\
\text { upper-secondary } \\
\text { level. }\end{array}$ & $\begin{array}{l}\text { Ministry of } \\
\text { Education and } \\
\text { Culture, } \\
\text { municipalities. }\end{array}$ & $\begin{array}{l}\text { The coordina- } \\
\text { tor of the } \\
\text { whole pro- } \\
\text { gramme is the } \\
\text { National } \\
\text { Board of } \\
\text { Education, } \\
\text { but the } \\
\text { networks } \\
\text { have their } \\
\text { own coordi- } \\
\text { nators. }\end{array}$ & $\begin{array}{l}\text { No programme board } \\
\text { for the programme as } \\
\text { a whole. Funded } \\
\text { networks may inde- } \\
\text { pendently organise } \\
\text { their work, including } \\
\text { working groups and } \\
\text { steering groups. }\end{array}$ & $\begin{array}{l}\text { Funding for networks } \\
\text { in upper-secondary } \\
\text { level and summer } \\
\text { schools in Russia. }\end{array}$ & $\begin{array}{l}\text { Information on the } \\
\text { total amount of } \\
\text { annual funding, } \\
\text { including both state } \\
\text { and municipal } \\
\text { funding, is unavaila- } \\
\text { ble. }\end{array}$ \\
\hline $\begin{array}{l}\text { Iceland Gover- } \\
\text { ment Scholar- } \\
\text { ships, Russians are } \\
\text { among the eligible } \\
\text { nationalities to } \\
\text { apply for scholar- } \\
\text { ships. }\end{array}$ & $\begin{array}{l}\text { Government } \\
\text { of Iceland } \\
\text { (Ministry of } \\
\text { Education, } \\
\text { Science and } \\
\text { Culture). }\end{array}$ & $\begin{array}{l}\text { Árni Magnús- } \\
\text { son Institute } \\
\text { for Icelandic } \\
\text { Studies, } \\
\text { Sigurður } \\
\text { Nordal Office. }\end{array}$ & $\mathrm{n} / \mathrm{a}$ & $\begin{array}{l}\text { Scholarships available } \\
\text { for foreign students of } \\
\text { Icelandic language } \\
\text { and literature to study } \\
\text { in Iceland. }\end{array}$ & $\begin{array}{l}\text { For the academic } \\
\text { year 2011-2012, } \\
\text { about } 15 \text { scholar- } \\
\text { ships were available } \\
\text { for all eligible } \\
\text { nationalities. Previ- } \\
\text { ously very few } \\
\text { applications came } \\
\text { from Russia. }\end{array}$ \\
\hline
\end{tabular}




\begin{tabular}{|c|c|c|c|c|c|}
\hline Programme & $\begin{array}{l}\text { Main funding } \\
\text { organisation }\end{array}$ & Coordinator & $\begin{array}{l}\text { Programme } \\
\text { board/steering group }\end{array}$ & $\begin{array}{l}\text { Forms of activities in } \\
\text { education/research }\end{array}$ & Volume \\
\hline $\begin{array}{l}\text { Fellowship pro- } \\
\text { gramme for } \\
\text { studies in High } \\
\text { North, Russia one } \\
\text { of the programme } \\
\text { countries. }\end{array}$ & $\begin{array}{l}\text { Ministry of } \\
\text { Foreign } \\
\text { Affairs of } \\
\text { Norway. }\end{array}$ & $\begin{array}{l}\text { Norwegian } \\
\text { Centre for } \\
\text { International } \\
\text { Cooperation } \\
\text { in Higher } \\
\text { Education } \\
\text { (SIU). }\end{array}$ & $\begin{array}{l}\text { Steering group of five } \\
\text { named profes- } \\
\text { sors/teaching staff } \\
\text { from Norwegian HEls, } \\
\text { mainly evaluates } \\
\text { applications. }\end{array}$ & $\begin{array}{l}\text { Scholarships for } \\
\text { Russian, US and } \\
\text { Canadian students to } \\
\text { study at institutions } \\
\text { of higher education in } \\
\text { Northern Norway, but } \\
\text { other activities are } \\
\text { also offered. }\end{array}$ & $\begin{array}{l}\text { The } 2010-2013 \\
\text { budget for the entire } \\
\text { programme is about } \\
\text { NOK } 13.5 \text { million. } \\
\text { About } 50 \% \text { of the } \\
\text { scholarships are } \\
\text { awarded to Russian } \\
\text { students. }\end{array}$ \\
\hline $\begin{array}{l}\text { Quota scheme } \\
\text { (quotas are also } \\
\text { granted to Russian } \\
\text { students) }\end{array}$ & $\begin{array}{l}\text { Ministry of } \\
\text { Education and } \\
\text { Research, } \\
\text { Norway. }\end{array}$ & $\begin{array}{l}\text { Norwegian } \\
\text { Centre for } \\
\text { International } \\
\text { Cooperation } \\
\text { in Higher } \\
\text { Education } \\
\text { (SIU) (Schol- } \\
\text { arships are } \\
\text { handled by } \\
\text { the Norwe- } \\
\text { gian State } \\
\text { Educational } \\
\text { Loan Fund). }\end{array}$ & $\begin{array}{l}\text { The programme has } \\
\text { no dedicated steering } \\
\text { group/board. }\end{array}$ & $\begin{array}{l}\text { The quota scheme } \\
\text { provides financial } \\
\text { support to study for } \\
\text { an entire degree in } \\
\text { Norway. }\end{array}$ & $\begin{array}{l}\text { Granted quota for } \\
\text { Russian students was } \\
133 \text { in the academic } \\
\text { year 2009-2010. The } \\
\text { annual quota is } \\
\text { about } 1100 \text { for } \\
\text { foreign students, and } \\
\text { the total funding in } \\
2009-2010 \text { was } \\
\text { about NOK } 103.6 \\
\text { million. }\end{array}$ \\
\hline $\begin{array}{l}\text { Norwegian studies } \\
\text { (Norgeskunnskap), } \\
\text { including activities } \\
\text { with Russia. }\end{array}$ & $\begin{array}{l}\text { Ministry of } \\
\text { Foreign } \\
\text { Affairs of } \\
\text { Norway } \\
\text { provides } \\
\text { funding for } \\
\text { actitivities } \\
\text { concerning } \\
\text { Russia. }\end{array}$ & $\begin{array}{l}\text { Norwegian } \\
\text { Centre for } \\
\text { International } \\
\text { Cooperation } \\
\text { in Higher } \\
\text { Education } \\
\text { (SIU). }\end{array}$ & $\begin{array}{l}\text { Steering board with } 4 \\
\text { members and } 4 \\
\text { deputy members. }\end{array}$ & $\begin{array}{l}\text { Various activities } \\
\text { intended to promote } \\
\text { Norway's internation- } \\
\text { al image and to } \\
\text { promote Norway } \\
\text { abroad. }\end{array}$ & $\begin{array}{l}\text { The budget in } 2010 \\
\text { was NOK } 7163500 \text {, } \\
\text { of which NOK } 1463 \\
500 \text { was allocated to } \\
\text { measures/activities } \\
\text { concerning Russia. }\end{array}$ \\
\hline $\begin{array}{l}\text { The Cooperation } \\
\text { Programme in } \\
\text { Higher Education } \\
\text { and Research } \\
\text { between Norway } \\
\text { and Russia 2007- } \\
\text { 2010. Information } \\
\text { on the new } \\
\text { programme for } \\
\text { cooperation with } \\
\text { Russia in higher } \\
\text { education una- } \\
\text { vailable. }\end{array}$ & $\begin{array}{l}\text { Norwegian } \\
\text { Ministry of } \\
\text { Foreign } \\
\text { Affairs. } \\
\text { Norwegian } \\
\text { Ministry of } \\
\text { Education has } \\
\text { provided } \\
\text { some extra } \\
\text { funding for } \\
\text { the pro- } \\
\text { gramme. }\end{array}$ & $\begin{array}{l}\text { Norwegian } \\
\text { Centre for } \\
\text { International } \\
\text { Cooperation } \\
\text { in Higher } \\
\text { Education } \\
\text { (SIU) and The } \\
\text { Research } \\
\text { Council of } \\
\text { Norway (for } \\
\text { the pro- } \\
\text { gramme } \\
2007-2010 \text { ). } \\
\text { SIU is the } \\
\text { coordinator } \\
\text { for the 2011 } \\
\text { programme. }\end{array}$ & $\begin{array}{l}\text { The } 2007-2010 \\
\text { programme had a } \\
\text { programme board. } \\
\text { The composition for } \\
\text { the new programme } \\
\text { is presently unavail- } \\
\text { ble. }\end{array}$ & $\begin{array}{l}\text { Programme period } \\
\text { 2007-2010: } 7 \text { projects } \\
\text { involved higher } \\
\text { education, } 8 \text { were } \\
\text { research projects. } \\
\text { Eligible activities } \\
\text { included research } \\
\text { cooperation, coopera- } \\
\text { tion based on the } \\
\text { Bologna process, } \\
\text { including develop- } \\
\text { ment of joint pro- } \\
\text { grammes, exchanges } \\
\text { of researchers, the } \\
\text { establishment of } \\
\text { networks, and the } \\
\text { organisation of events } \\
\text { (seminars, confer- } \\
\text { ences and work- } \\
\text { shops). }\end{array}$ & $\begin{array}{l}\text { The total budget for } \\
2007-2010 \text { was NOK } \\
48 \text { million. }\end{array}$ \\
\hline Barentsplus. & $\begin{array}{l}\text { Norwegian } \\
\text { Barents } \\
\text { Secretariat } \\
\text { (Ministry for } \\
\text { Foreign } \\
\text { Affairs of } \\
\text { Norway). }\end{array}$ & $\begin{array}{l}\text { Finnmark } \\
\text { University } \\
\text { College. }\end{array}$ & $\begin{array}{l}\text { Under RHU (rådet for } \\
\text { høgere utdanning i } \\
\text { Nord-Norge/The } \\
\text { association of higher } \\
\text { education institutions } \\
\text { in North Norway), an } \\
\text { official advisory group } \\
\text { called Nordflanken } \\
\text { serves } \\
\text { as the reference } \\
\text { group for the pro- } \\
\text { gramme. }\end{array}$ & $\begin{array}{l}\text { Exchange programme } \\
\text { for students and } \\
\text { teachers in institu- } \\
\text { tions of higher } \\
\text { education in the } \\
\text { Russian and Norwe- } \\
\text { gian Barents region. }\end{array}$ & $\begin{array}{l}\text { Annual budget is } \\
\text { about NOK } 800000 \text {. }\end{array}$ \\
\hline
\end{tabular}




\begin{tabular}{|c|c|c|c|c|c|}
\hline Programme & $\begin{array}{l}\text { Main funding } \\
\text { organisation }\end{array}$ & Coordinator & $\begin{array}{l}\text { Programme } \\
\text { board/steering group }\end{array}$ & $\begin{array}{l}\text { Forms of activities in } \\
\text { education/research }\end{array}$ & Volume \\
\hline $\begin{array}{l}\text { Projects funded by } \\
\text { Norwegian } \\
\text { Barents Secretari- } \\
\text { at. }\end{array}$ & $\begin{array}{l}\text { Owned by the } \\
\text { three north- } \\
\text { ernmost } \\
\text { counties of } \\
\text { Norway: } \\
\text { Nordland, } \\
\text { Troms and } \\
\text { Finnmark; } \\
\text { financed by } \\
\text { the Ministry } \\
\text { of Foreign } \\
\text { Affairs of } \\
\text { Norway and } \\
\text { other minis- } \\
\text { tries. }\end{array}$ & $\begin{array}{l}\text { Norwegian } \\
\text { Barents } \\
\text { Secretariat. }\end{array}$ & $\begin{array}{l}\text { The Norwegian } \\
\text { Barents Secretariat } \\
\text { has a board, but no } \\
\text { dedicated steering } \\
\text { group for priority area } \\
\text { "competence" or } \\
\text { other priority areas. }\end{array}$ & $\begin{array}{l}\text { Funding for education } \\
\text { projects under the } \\
\text { priority theme } \\
\text { "Competence". }\end{array}$ & $\begin{array}{l}\text { No annual funding } \\
\text { earmarked for any of } \\
\text { the priority areas. } \\
\text { Overall } 2009 \text { budget } \\
\text { for the entire pro- } \\
\text { ject, including all the } \\
\text { priority areas, was } \\
\text { about NOK } 28 \\
\text { million. }\end{array}$ \\
\hline $\begin{array}{l}\text { Yggdrasil, Russia } \\
\text { among the } \\
\text { programme } \\
\text { countries. }\end{array}$ & $\begin{array}{l}\text { Researh } \\
\text { Council of } \\
\text { Norway. }\end{array}$ & $\begin{array}{l}\text { Research } \\
\text { Council of } \\
\text { Norway. }\end{array}$ & $\begin{array}{l}\text { The same programme } \\
\text { board as for the } \\
\text { International Scholar- } \\
\text { ships coordinated by } \\
\text { the Research Counil. } \\
\text { The board includes } \\
\text { seven representatives } \\
\text { from Norwegian } \\
\text { institutions of higher } \\
\text { education. }\end{array}$ & $\begin{array}{l}\text { Mobility programme, } \\
\text { which offers grants to } \\
\text { international PhD } \\
\text { students and young } \\
\text { researchers to carry } \\
\text { out research in } \\
\text { Norway. }\end{array}$ & $\begin{array}{l}\text { The annual budget is } \\
\text { about NOK } 10 \\
\text { million. For the } 2011 \\
\text { call, about NOK } 2 \\
\text { million is earmarked } \\
\text { to increase the } \\
\text { mobility of research- } \\
\text { ers from Brazil and } \\
\text { Russia in the fields of } \\
\text { mathematics, natural } \\
\text { sciences and engi- } \\
\text { neering. }\end{array}$ \\
\hline $\begin{array}{l}\text { NORRUSR (Russia } \\
\text { and internatinal } \\
\text { relations in the } \\
\text { northern areas). }\end{array}$ & $\begin{array}{l}\text { Thus far, } \\
\text { financing of } \\
\text { the pro- } \\
\text { gramme } \\
\text { comes only } \\
\text { from the } \\
\text { Ministry of } \\
\text { Foreign } \\
\text { Affairs of } \\
\text { Norway. }\end{array}$ & $\begin{array}{l}\text { Research } \\
\text { Council of } \\
\text { Norway. }\end{array}$ & $\begin{array}{l}\text { International pro- } \\
\text { gramme board with } \\
\text { chair, } 6 \text { members, } 2 \\
\text { deputy members and } \\
1 \text { observer. }\end{array}$ & $\begin{array}{l}\text { Research programme } \\
\text { for Norwegian re- } \\
\text { search institutions. It } \\
\text { is social sciences- } \\
\text { oriented and aims to } \\
\text { strengthen knowledge } \\
\text { on Russia. }\end{array}$ & $\begin{array}{l}\text { Total budget of the } \\
\text { programme to be } \\
\text { announced in } 2011 \text {. }\end{array}$ \\
\hline $\begin{array}{l}\text { Research Council } \\
\text { of Norway and } \\
\text { other Russia } \\
\text { activities and } \\
\text { programmes } \\
\text { related to Russia } \\
\text { (e.g., PETROMAKS } \\
\text { and PETROSAM). }\end{array}$ & $\mathrm{n} / \mathrm{a}$ & $\begin{array}{l}\text { Research } \\
\text { Council of } \\
\text { Norway. }\end{array}$ & $\mathrm{n} / \mathrm{a}$ & $\begin{array}{l}\text { At least research } \\
\text { programmes PETRO- } \\
\text { MAKS and PETROSAM } \\
\text { have activities with } \\
\text { Russia. Annual Arctic } \\
\text { Offshore Workshops } \\
\text { between the RCN and } \\
\text { RAS. }\end{array}$ & $\mathrm{n} / \mathrm{a}$ \\
\hline $\begin{array}{l}\text { County of Finn- } \\
\text { mark cooperation } \\
\text { programme with } \\
\text { north-western } \\
\text { Russia. }\end{array}$ & $\begin{array}{l}\text { Ministry of } \\
\text { Education and } \\
\text { Science, } \\
\text { Norway. }\end{array}$ & $\begin{array}{l}\text { Education } \\
\text { Department } \\
\text { of the County } \\
\text { of Finnmark. }\end{array}$ & $\begin{array}{l}\text { No dedicated steering } \\
\text { group for the pro- } \\
\text { gramme. }\end{array}$ & $\begin{array}{l}\text { Funding for joint } \\
\text { school projects with } \\
\text { north-western Russia } \\
\text { and the County of } \\
\text { Finnmark. }\end{array}$ & $\begin{array}{l}\text { NOK } 2 \text { million } \\
\text { annually. }\end{array}$ \\
\hline $\begin{array}{l}\text { Norwegian } \\
\text { University Centre } \\
\text { in Saint Peters- } \\
\text { burg. }\end{array}$ & $\begin{array}{l}\text { Universities in } \\
\text { Bergen, Oslo, } \\
\text { Troms } \varnothing \text { and } \\
\text { Trondheim } \\
\text { (NTNU). }\end{array}$ & $\mathrm{n} / \mathrm{a}$ & $\begin{array}{l}\text { Board consists of } \\
\text { representatives from } \\
\text { the University of } \\
\text { Begen, University of } \\
\text { Oslo, University of } \\
\text { Troms } \varnothing \text { and Norwe- } \\
\text { gian University of } \\
\text { Science and Technol- } \\
\text { ogy (NTNU). }\end{array}$ & $\begin{array}{l}\text { Russian language } \\
\text { courses for Norwe- } \\
\text { gian students, courses } \\
\text { in political science, } \\
\text { research cooperation, } \\
\text { hosting of stu- } \\
\text { dents/researchers. }\end{array}$ & $\begin{array}{l}\text { Annual budget is } \\
\text { about NOK } 3.5 \\
\text { million. }\end{array}$ \\
\hline $\begin{array}{l}\text { Support of de- } \\
\text { mocracy and } \\
\text { human rights in } \\
\text { Russia for 2010- } \\
2012 \text {. }\end{array}$ & $\begin{array}{l}\text { Ministry of } \\
\text { Foreign } \\
\text { Affairs of } \\
\text { Sweden. }\end{array}$ & $\begin{array}{l}\text { Swedish } \\
\text { International } \\
\text { Development } \\
\text { Cooperation } \\
\text { Agency } \\
\text { (Sida)/the } \\
\text { Swedish } \\
\text { Institute. }\end{array}$ & $\mathrm{n} / \mathrm{a}$ & $\begin{array}{l}\text { All activities not yet } \\
\text { specified, but at least } \\
\text { support provided for } \\
\text { Moscow School of } \\
\text { Political Science in the } \\
\text { field of education. }\end{array}$ & $\begin{array}{l}\text { Annual budget for } \\
\text { the entire pro- } \\
\text { gramme is about SEK } \\
37 \text { million. }\end{array}$ \\
\hline
\end{tabular}




\begin{tabular}{|c|c|c|c|c|c|}
\hline Programme & $\begin{array}{l}\text { Main funding } \\
\text { organisation }\end{array}$ & Coordinator & $\begin{array}{l}\text { Programme } \\
\text { board/steering group }\end{array}$ & $\begin{array}{l}\text { Forms of activities in } \\
\text { education/research }\end{array}$ & Volume \\
\hline $\begin{array}{l}\text { Visby Programme; } \\
\text { Russia is one of } \\
\text { the most priori- } \\
\text { tised countries. }\end{array}$ & $\begin{array}{l}\text { Ministry of } \\
\text { Foreign } \\
\text { Affairs of } \\
\text { Sweden. }\end{array}$ & $\begin{array}{l}\text { Swedish } \\
\text { Institute }\end{array}$ & $\begin{array}{l}\text { No steering group at } \\
\text { the moment. The } \\
\text { programme has an } \\
\text { assessment team that } \\
\text { assists in evaluating } \\
\text { applications. }\end{array}$ & $\begin{array}{l}\text { For project funding } \\
\text { and individual schol- } \\
\text { arships, see details in } \\
\text { the text on Sweden. } \\
\text { The Swedish Institute } \\
\text { also coordinates the } \\
\text { programme related to } \\
\text { teaching Swedish } \\
\text { language abroad, } \\
\text { including teaching } \\
\text { Swedish in Russia. } \\
\text { This is not part of the } \\
\text { Visby Programme, but } \\
\text { is an own programme. }\end{array}$ & $\begin{array}{l}\text { The budget for the } \\
\text { entire Visby Pro- } \\
\text { gramme in } 2011 \text { is } \\
\text { about SEK } 56447 \\
\text { 000. The prioritised } \\
\text { countries are Bela- } \\
\text { rus, Ukraine and } \\
\text { Russia. Other pro- } \\
\text { gramme countries } \\
\text { include Estonia, } \\
\text { Latvia, Lithuania and } \\
\text { Poland. }\end{array}$ \\
\hline $\begin{array}{l}\text { Research on } \\
\text { politically im- } \\
\text { portant geograph- } \\
\text { ic regions (includ- } \\
\text { ing research on } \\
\text { Russia). }\end{array}$ & $\begin{array}{l}\text { Government } \\
\text { of Sweden }\end{array}$ & $\begin{array}{l}\text { Uppsala } \\
\text { Universi- } \\
\text { ty/Uppsala } \\
\text { Centre for } \\
\text { Russian and } \\
\text { Eurasian } \\
\text { Studies. }\end{array}$ & $\begin{array}{l}\text { Board consist of chair } \\
\text { and } 6 \text { members. }\end{array}$ & $\begin{array}{l}\text { Aim is to develop a } \\
\text { national resource } \\
\text { center on research } \\
\text { and analysis of Russia } \\
\text { and the post-Soviet } \\
\text { space. }\end{array}$ & $\mathrm{n} / \mathrm{a}$ \\
\hline $\begin{array}{l}\text { Östersjöstiftelsen } \\
\text { (The Foundation } \\
\text { for Baltic and East } \\
\text { European Stud- } \\
\text { ies). }\end{array}$ & $\begin{array}{l}\text { Founded by } \\
\text { the Swedish } \\
\text { Government } \\
\text { in } 1994 .\end{array}$ & $\begin{array}{l}\text { The office of } \\
\text { the founda- } \\
\text { tion. Centre } \\
\text { for Baltic and } \\
\text { East European } \\
\text { Studies/Baltic } \\
\text { and East } \\
\text { European } \\
\text { Graduate } \\
\text { School at } \\
\text { Södertörn } \\
\text { University. }\end{array}$ & $\begin{array}{l}\text { Board, including chair } \\
\text { and } 8 \text { members. }\end{array}$ & $\begin{array}{l}\text { To support research } \\
\text { and doctoral studies, } \\
\text { as well as the aca- } \\
\text { demic infrastructure } \\
\text { at Södertörns högsko- } \\
\text { la (Södertörn Univer- } \\
\text { sity) (also includes } \\
\text { research on Russia). }\end{array}$ & $\begin{array}{l}\text { In recent years, } \\
\text { Södertörn University } \\
\text { has received SEK } 200 \\
\text { million annually from } \\
\text { the Foundation for } \\
\text { Baltic and East } \\
\text { European Studies. }\end{array}$ \\
\hline $\begin{array}{l}\text { Knowledge } \\
\text { Building and } \\
\text { Networking } \\
\text { Programme with } \\
\text { North-West } \\
\text { Russia, including } \\
\text { the programme } \\
\text { for cooperation in } \\
\text { research and } \\
\text { education. }\end{array}$ & $\begin{array}{l}\text { Nordic } \\
\text { Council of } \\
\text { Ministers (on } \\
\text { the Nordic } \\
\text { side). }\end{array}$ & $\begin{array}{l}\text { NordForsk } \\
\text { and SIU (on } \\
\text { the Nordic } \\
\text { side). }\end{array}$ & $\begin{array}{l}\text { Information currently } \\
\text { unavailable. }\end{array}$ & $\begin{array}{l}\text { Information currently } \\
\text { unavailable. }\end{array}$ & $\begin{array}{l}\text { Information current- } \\
\text { ly unavailable. }\end{array}$ \\
\hline EuroFaculty Pskov. & $\begin{array}{l}\text { Council of the } \\
\text { Baltic Sea } \\
\text { States. }\end{array}$ & $\begin{array}{l}\text { Sweden is } \\
\text { Lead Country. } \\
\text { Turku School } \\
\text { of Economics } \\
\text { is the Consor- } \\
\text { tium's Lead } \\
\text { University. }\end{array}$ & $\begin{array}{l}\text { International Expert } \\
\text { Group for the Eu- } \\
\text { roFaculty Pskov. }\end{array}$ & $\begin{array}{l}\text { The aim is to upgrade } \\
\text { university education } \\
\text { in business economics } \\
\text { at Pskov State Poly- } \\
\text { technic Institute. }\end{array}$ & $\begin{array}{l}\text { Budget of the project } \\
\text { comprised of cash } \\
\text { contributions total- } \\
\text { ling EUR } 953164 \text {. In } \\
\text { addition in-kind } \\
\text { contributions. }\end{array}$ \\
\hline
\end{tabular}

